2020-06

Translation equivalent and

cross-language semantic priming in

bilingual toddlers

\title{
Floccia, Caroline
}

http://hdl.handle.net/10026.1/15256

\subsection{6/j.jml.2019.104086 \\ Journal of Memory and Language \\ Elsevier}

All content in PEARL is protected by copyright law. Author manuscripts are made available in accordance with publisher policies. Please cite only the published version using the details provided on the item record or document. In the absence of an open licence (e.g. Creative Commons), permissions for further reuse of content should be sought from the publisher or author. 
Translation Equivalent and Cross-Language Semantic Priming in Bilingual Toddlers

\author{
Caroline Floccia (1) \\ Claire Delle Luche (2) \\ Irina Lepadatu (3) \\ Janette Chow (3) \\ Paul Ratnage (1) \\ Kim Plunkett (3)
}

(1) University of Plymouth, Drake Circus, PL4 8AA Plymouth, UK

(2) University of Essex, Wivenhoe Park, Colchester CO4 3SQ, UK

(3) University of Oxford, Anna Watts Building, Radcliffe Observatory Quarter, Woodstock Rd, Oxford OX2 6GG, UK

Corresponding author: Caroline Floccia, School of Psychology, University of Plymouth, Drake Circus, PL4 8AA, Plymouth, UK. caroline.floccia@plymouth.ac.uk; tel +44 1752584822 


\begin{abstract}
In adult bilinguals, a word in one language will activate a related word in the other language, with language dominance modulating the direction of these effects. To determine whether the early bilingual lexicon possesses similar properties to its adult counterpart, two experiments compared translation equivalent priming and cross-linguistic semantic priming in 27-month-old bilingual toddlers learning English and one other language. Priming effects were found in both experiments, irrespective of language dominance and distance between the child's two languages. The time course of target word recognition revealed a similar pattern for translation equivalent priming and cross-language semantic priming. These results suggest that the early bilingual lexicon possesses properties similar to the adult one in terms of word to concept connections. However, the absence of an advantage of translation equivalent priming over semantic priming, and the lack of dominance and language distance effects, suggest that when two languages are acquired in parallel during infancy, their integration within a single dynamic system is highly robust to input variations.
\end{abstract} Keywords: bilingual lexicon - toddlers - word processing - priming - language dominance language distance. 
Highlights

- Translation equivalent priming and cross-language semantic priming are found in bilingual 27-month-olds.

- $\quad$ Contrary to adult findings, timescale and magnitude are similar for these two types of priming.

- $\quad$ Contrary to adult findings, no effect of language dominance is found.

- $\quad$ Contrary to model predictions, no effect of language distance is found.

- The early bilingual lexicon may not be a miniature version of the adult one. 
Translation Equivalent and Cross-Language Semantic Priming in Bilingual Toddlers

Bilingual toddlers, like their monolingual peers, start producing words by their first birthday (Vihman, Thierry, Lum, Keren-Portnoy, \& Martin, 2007) and engage in rapid word learning during their second year. The properties of the early bilingual lexicon, in terms of size and content, have been well documented over the past two decades (e.g. Bialystok, Luk, Peets, \& Yang, 2010; Bilson, Yoshida, Tran, Woods, \& Hills, 2015; Cattani et al., 2014; De Houwer, Bornstein, \& Putnick, 2014; Floccia et al., 2018; Gross, Buac, \& Kaushanskaya, 2014; Hoff et al., 2012; Oller \& Eilers, 2002; Pearson, Fernández, \& Oller, 1995;

Thordardottir, Rothenberg, Rivard, \& Naves, 2006), fuelling a theoretical debate as to whether bilingual children initially develop a unique, undifferentiated language system (e.g. Volterra \& Taeschner, 1978), two parallel and independent systems (e.g. Genesee, Nicoladis, \& Paradis, 1995), or more recently, two separate, yet interfering, systems (ByersHeinlein, 2014; Hoff, 2013).

What is less documented is the internal structure of the initial bilingual lexicon, in terms of connectivity and organisation (see the review by DeAnda, Poulin-Dubois, Zesiger, \& Friend, 2016). It is unclear whether the early bilingual lexicon is a miniature version of the adult bilingual lexicon, or whether it grows into the adult architecture from a different configuration. Similar questions have been addressed recently regarding the early monolingual lexicon (e.g. Arias-Trejo \& Plunkett, 2009; Chow, Aimola Davies, Fuentes, \& Plunkett, 2016, 2018; Delle Luche, Durrant, Floccia, \& Plunkett, 2014; Hills, Maouene, Maouene, Sheya, \& Smith, 2009; Mani, Durrant \& Floccia, 2012), with the added complexity here that bilingual lexical development is modulated by additional contextual factors, related to the quality and quantity of dual language exposure, and to linguistic distance between the two languages (see Floccia et al., 2018; Havy, Bouchon, \& Nazzi, 
2015).

The existing literature suggests that two key features of the adult bilingual lexicon seem to be present in toddlers. First, non-selective access has been found repeatedly: upon hearing a word in one language, bilingual children automatically activate related words in their other language (Jardak \& Byers-Heinlein, 2018; Singh, 2014; Von Holzen, Fennell \& Mani, 2018; Von Holzen \& Mani, 2012; in adults, see for example Spivey \& Marian, 1999). Second, evidence for an asymmetry of cross-language activation as a function of language dominance has been reported (Singh, 2014; Von Holzen, Fennell, \& Mani, 2018; in adults, see for example Weber \& Cutler, 2004): forward semantic priming ( $L 1^{1}$ to $L 2$ ) is more robust than backward priming (L2 to L1) (but see Jardak \& Byers-Heinlein, 2018). The aim of this paper is to examine another potential feature of the early bilingual lexicon, also characteristic of the adult bilingual lexicon, namely the modulation of activation across languages as a function of the degree of semantic and phonological overlap between words.

The adult literature has established that cross-language priming between related words is stronger and faster for words with a high degree of semantic overlap such as translation equivalents (e.g. dog and Hund-dog in German), than for less overlapping semantically related words (e.g. dog and Katze - cat in German; see Schoonbaert, Duyck, Brysbaert, \& Hartsuiker, 2009, for a review in visual word recognition). As we will discuss further, the very few similar studies in toddlers (Jardak \& Byers-Heinlein, 2018; Singh, 2014; Von Holzen \& Mani, 2012) offer mixed results, and have not directly compared the effect of the degree of overlap on cross-linguistic word activation. In addition, current models of

\footnotetext{
${ }^{1}$ We use the terms L1 and L2 to refer to dominant and non-dominant languages, with no reference to age of acquisition, as the young population we discuss here would generally have been exposed to the two languages from birth.
} 
developmental bilingual word processing (BIA-d: Grainger, Midgley, \& Holcomb, 2010; BLINCS: Shook \& Marian, 2013; DevLex-II: Zhao \& Li, 2010, 2013; PRIMIR: Curtin, ByersHeinlein \& Werker, 2011; SOMBIP: Li \& Farkas, 2002) differ as to whether and how they predict coalescence of cross-language overlapping competitors as a function of overlap in meaning and form (see DeAnda et al., 2016, for a discussion of DevLex-II and PRIMIR). Here we will examine the effect of cross-language overlap in spoken word recognition in two ways: first, we will evaluate the impact of semantic overlap between words, by comparing translation equivalent priming (e.g. dog/chien - dog in French; Exp 1) and cross-linguistic semantic priming (e.g. cat/chien; Exp 2). Second, we will examine how phonological overlap modulates cross-language word activation by looking at how priming data, within each of those experiments, are affected by the linguistic distance between the child's two languages, in terms of phonological/lexical overlap. In the general discussion we will also examine how our data support the two most recent implemented models of bilingual development, BLINCS (Shook \& Marian, 2013) and DevLex-II (Zhao \& Li, 2010, 2013). Translation equivalent priming: direction of the effect

The starting point of this study was a recent set of conflicting data obtained with a very similar paradigm in spoken word recognition - covert priming - indicating that translation equivalent priming could be wired differently in adults and infants. Shook and Marian (2017), using a visual world paradigm, found that English-Spanish adults asked to identify the picture of a duck, looked longer at the picture of a shovel than at unrelated picture distracters. The explanation is that duck activates its Spanish translation equivalent pato (covert priming), which in turns activates its phonological neighbour pala (meaning shovel). The authors interpreted their findings as showing lateral excitatory links between translation equivalents. 
However, the exact opposite result was reported by Von Holzen and Mani (2012) with 17 German/English bilingual toddlers aged 21 to 43 months, in a similar covert priming situation. Three conditions of cross-linguistic priming were used: phonological, e.g. slide/Kleid (dress in German); phonological through translation, e.g. leg/Stein (stone in German, which overlaps with Bein - leg in German); and unrelated, e.g. mouth/Buch (book). All children were considered to be German dominant due to their exposure situation. As would be expected from monolingual adult studies in phonological priming (Radeau, Morais, \& Segui, 1995), children were faster to identify the target in the phonological condition than in the unrelated one (e.g. slide primes Kleid). More interestingly, a difference was found between the phonological through translation condition and the unrelated one, so that children were slower to recognise Stein after leg, as compared to the control. Although the overall pattern of results suggests that activation of words across languages takes place in toddlers as it does in adults, the direction of the result (an inhibition of target recognition) was quite unexpected.

In sum, although the two studies (Shook \& Marian, 2017; Von Holzen \& Mani, 2012) converge to show non-selective lexical access, they diverge in the direction of the effect: covert priming leads to interference between translation equivalents in Von Holzen and Mani (2012), but facilitation in Shook and Marian (2017).

In addition to explanations based on differences in population characteristics, stimuli selection and methodological details, it is possible that the early bilingual lexicon may be characterised by more lateral inhibition than its adult version (as seen in TRACE: McClelland \& Elman, 1986, or Shortlist: Norris, 1994). Lateral inhibition would lead to a 
translation equivalent disadvantage, as opposed to the advantage typically seen in adults, which would explain the conflicting results found by Von Holzen and Mani (2012) and Shook and Marian (2017). Another possibility is that the conflicting results reflect simultaneous acquisition (as in children tested in Von Holzen \& Mani, although these children were primarily exposed to L2, English, in nursery and not at home) versus late acquisition (as in Shook \& Marian).

Further recent data complicate the observations raised from the previous studies. Poulin-Dubois, Kuzyk, Legacy, Zeziger and Friend (2017) measured reaction times to translation and non-translation equivalents in a word identification task (using a touch screen) in 22-month-old bilingual French-English toddlers. It was found that children were overall faster to recognise translation equivalent words over non-translation equivalents, both in the dominant and non-dominant language (dominance defined by exposure). This was interpreted as implicit excitatory activation between translation equivalents, whenever a target word was presented in one given language.

Forward versus backward priming effects

The nature of the relation between translation equivalents or semantic neighbours is also informed by the large body of adult data on the effects of language dominance on priming. The picture to date is that excitatory links are often found for forward priming (L1 to L2) but not backward priming (L2 to L1), with data mainly coming from masked translation priming in visual word recognition, and to a lesser extent, from cross-linguistic semantic priming (see the review in Schoonbaert et al., 2009). These findings run against predictions from early models of bilingual word processing, the RHM (Kroll \& Stewart, 1994; Kroll, van Hell, Tokowicz \& Green, 2010). The RHM, a model of the late and unbalanced bilingual - which is the typical profile of most participants involved in bilingual adult studies 
(as in Shook \& Marian, 2017, for example) - predicted stronger and faster excitatory connections between translation equivalents in backward priming, rather than the opposite, forward priming (Jared \& Kroll, 2001). This was thought to be due to a direct lexical connection between translation equivalents (that is, not transiting through semantic features), with a stronger clamp from L2 words to L1 words rather than the opposite. However, the repeated finding that forward priming is stronger than backward priming has led researchers to propose other routes for explaining asymmetrical translation (and semantic) cross-linguistic priming effects, such as in the Distributed Representational Model - DRM (de Groot, 1992; Duyck \& Brysbaert, 2004). In this proposal the directional activation of shared semantic features can account elegantly for the backward/forward asymmetry (see also the Sense model by Finkbeiner, Forster, Nicol, \& Nakamura, 2004, which uses asymmetry in language-specific polysemy to account for dominance effects).

In spoken word recognition, which is overall less documented than visual word recognition, forward priming is sometimes found to be more robust than backward priming (Marian, Blumenfeld \& Boukrina, 2008; Spivey \& Marian, 1999), or the other way round (Blumenfeld \& Marian, 2007; Ju \& Luce, 2004; Marian \& Spivey, 2003a, 2003b; Weber \& Cutler, 2004). Effect of stimulus selection, participant selection, language mode, might all contribute to explain the variability in this area.

To our knowledge, no studies have examined the effects of dominance in translation equivalent priming in toddlers, but two papers have reported conflicting results in crosslinguistic semantic priming. Singh (2014) recently demonstrated stronger forward priming than backward priming in a group of 21 30-month-old Mandarin-English toddlers. More specifically, and compatible with Basnight-Brown and Altarriba (2007) in adults, she found that a prime in the dominant language (defined by exposure) would boost recognition of a 
semantically related target in the non-dominant language (forward priming), but no priming effect was found for the opposite pairing (backward). One explanation offered by Singh for this asymmetrical result is based on word familiarity: familiar words tend to gain some processing privileges as compared to less familiar words in childhood (e.g. Mills, Plunkett, Prat \& Schafer, 2005); if those words happened to be in the dominant language, that could explain that forward priming is more robust than backward priming.

However, Jardak and Byers-Heinlein (2018) who recently reported evidence of crosslinguistic semantic priming in a group of 16 30-month-olds learning French and English, found no effect of language dominance. That is, forward and backward priming were similarly apparent. Their results with 24-months-olds were unclear: comparing monolingual and bilingual toddlers (using within-language priming for monolinguals), they found no interaction between priming and language group. Yet they reported priming in the monolingual group, but not in the bilingual group.

Experiment 1, which explicitly examines translation equivalents priming in toddlers, aims to clarify the nature of the link between translation equivalents, as a function of language dominance and exposure. Language dominance will be estimated through a measure of relative exposure to each language (e.g., Singh, 2014), but also through a measure of language ability through vocabulary scores provided by the Oxford Communicative Development Inventories (CDI) scales (e.g. Hamilton, Plunkett \& Schafer, 2000). Whereas exposure is considered to be a reasonable proxy for language dominance in children (Unsworth, 2012), in adult studies dominance is more often assessed by proficiency self-reports (e.g. Basnight-Brown \& Altarriba, 2007; Ivanova \& Costa, 2008; but see Chen, Bobb, Hoshino, \& Marian, 2017) which, in children, translate better in measures of vocabulary knowledge than mere exposure. 
Effect of phonological overlap through language distance

In addition to semantic overlap effects (in translation equivalent or semantic priming), cross-language phonological overlap effects have also been repeatedly reported in adult bilingual research (e.g. Chen \& Marian, 2016; Colomé \& Miozzo, 2010; Duyck, 2005), and demonstrated recently in German-English toddlers with rime-sharing competitors (Von Holzen \& Mani, 2012) and competitors varying (mainly) on non-initial vowel (Von Holzen et al., 2018). Rather than (re)-examining whether cross-language phonological priming is possible in early childhood, here we will ask whether the overall language distance between L1 and L2, in terms of phono-lexical overlap, has any impact on the internal configuration of the bilingual lexicon.

Recent support for an effect of language distance on bilingual development comes from the study of a group of 372 24-month-old toddlers learning British English and one of 13 additional languages, whose productive vocabulary in the additional language was found to be predicted by language distance, measured by the degree of lexical/phonological overlap between the child's two languages (Floccia et al., 2018). Children learning British English and a language with a high phono-lexical overlap such as Dutch or German, produced more words in their home language than children learning a more distant language such as Bengali and Greek. This would suggest that in close languages, there would be more language integration than separation, leading to closer links between lexical items across languages, and therefore stronger translation equivalent priming effects, as compared to distant languages. To evaluate this prediction, we will test toddlers learning British English and one of several different language backgrounds (Cantonese, Dutch, French, German, Italian, Mandarin, Polish, Portuguese and Spanish), spanning a range of values for L1-L2 distance. 
One of the aims of this paper was to evaluate whether empirical data would fit predictions from current computational models of bilingual lexical development (DevLex-II: Zhao \& Li, 2010, 2013; BLINCS: Shook \& Marian, 2013) about the comparison between translation equivalent priming and semantic priming, the role of dominance and the effect of language distance on word-to-word activation.

Devlex-II is a development of a computational model of the developing monolingual lexicon (DevLex: Li, Farkas, \& MacWhinney, 2004) which was slightly modified to account for the bilingual situation (Zhao \& Li, 2007, 2010, 2013). It relies on three self-organising maps designed to model a comprehension and a production route: an input phonology map, a semantic map and a phonological output sequence map. Trained with 1000 words, half Chinese, half English, with some (unspecified) proportion of translation equivalents, it was adjusted to mimic early acquisition and late acquisition of the second language (Zhao \& Li, 2013). In the early acquisition mode, which is closer to what toddlers tested in our experiments would have experienced, the model produced a clear language separation on the semantic and the phonological maps (note that the separation on the semantic map is due to the use of language-specific semantic features to code each word, as well as to the use of a set of words in each language that differed substantially). The model was then used to analyse different situations of priming, including comparing translation equivalent and semantic priming, using a set of 32 pairs of translation equivalents and 32 pairs of crosslanguage semantically related words (Zhao \& Li, 2013).

The most important effect found in DevLex-II is that translation equivalent priming is always found to be faster than cross-linguistic semantic priming. Using an SOA of $150 \mathrm{~ms}$, the model produced a $120 \mathrm{~ms}$ advantage for translation priming (in the early L2 learning condition). Regarding priming asymmetries, DevLex-II produces stronger forward priming 
(from L1 to L2) than backward priming (from L2 to L1) for translation equivalent priming, consistent with most adult literature. Finally, regarding linguistic distance, DevLex-II was only trained with English and Chinese, two languages with very little lexico-phonological overlap. After training, the model shows clear language separation on all maps, in the case of early and simultaneous acquisition (Zhao \& Li, 2010). The most likely outcome of training the model with two closer languages would be (1) a less clear cut separation of the two languages on all maps, driven by more overlapping phonotactic and phonological inventories carrying over from one map to the next, and perhaps (2) a delay in reaching a stable state of separation. These predictions would translate into stronger cross-language priming effects for close language learners, as well as a delay in word learning for children exposed to close languages as compared to distant languages (which is not what was reported in Floccia et al., 2018).

BLINCS is a model of bilingual word comprehension specifically developed for the case of simultaneous acquisition (Shook \& Marian, 2013). It contains three successive selforganising maps representing phonological, phono-lexical and semantic information respectively. The model was trained with 240 English words and 240 Spanish words, with a large proportion of translation equivalents (142 pairs) and cognates (88 pairs), probably a more realistic representation of a bilingual child's experience. After training, two separate yet integrated lexicons emerged on the phono-lexical map, based on phonotactic information, with cognates mapped close to one another at the junction of languagespecific areas. The separation was far less clear on the semantic map (the same semantic vectors were used for the two languages, contrary to DevLex-II), with cognates represented under the same unit. Words that were closely mapped were co-activated, with lateral links for translation equivalents gradually built up in the phono-lexical map. Results model the 
priming effect between translation equivalents, due to activation from the semantic map propagating back onto the phono-lexical map. It also reproduces the advantage of cognate recognition in terms of speed and accuracy (e.g. van Hell \& Dijkstra, 2002). Although not detailed in the paper, the model would successfully model semantic priming since semantic neighbours (e.g. road/car) were mapped closely on the semantic map. Here too we would expect translation equivalent priming to be stronger than semantic priming, as deduced from examples of coactivation provided by the authors. Indeed, most coactivated words were either translation equivalents or phonologically related words, never cross-linguistic semantic neighbours, suggesting weaker activation patterns between semantically related words across languages.

BLINCS is a model of the simultaneous bilingual, and as such, is not designed to address predictions related to language dominance, which are usually modelled by delayed acquisition. Yet the model can be augmented by a language inhibition function that can represent dominance, and potentially reproduce asymmetries in language-switching tasks (e.g. Gollan \& Ferreira, 2009). It is likely that it would also predict effects of dominance on priming, but whether inhibition of one language system to represent dominance is a correct representation of the early bilingual child's experience remains uncertain.

Trained on English and Spanish, which are closer than Chinese and English in terms of phono-lexical overlap, the model achieved a reasonable separation on the phono-lexical map, with distinct islands of language-specific words. Since this separation was driven by phonotactic information, it is likely that the degree of separation on the low-level map can be modulated by the degree of phonotactic or phonological overlap between the two languages. But it is also possible that language distance modulates the time needed to reach a stable state of separation, with more time needed to stabilise close languages. 


\section{Rationale}

To examine the impact of between-language word overlap on the architecture of the early bilingual lexicon, we will first evaluate priming between translation equivalents (Experiment 1) in 27-month-old bilingual toddlers. Based on adult findings, we expect facilitatory links between translation equivalents. Alternatively, translation equivalents might inhibit one another in early childhood, as in Von Holzen and Mani's covert priming study (2012). We also expect stronger forward priming than backward priming (the most common finding in adults), and effects of linguistic distance between the children's two languages with stronger priming between close languages rather than distant languages.

In Experiment 2, we will examine the weaker case of between-language overlap, namely cross-language priming between semantically related words. Based on adult findings (e.g. Basnight-Brown \& Altarriba, 2007), we would expect translation priming (Experiment 1) to be stronger than semantic priming (Experiment 2).

The data from these two experiments will be used in the general discussion to examine how they can be accounted for by DevLex-II (Zhao \& Li, 2010, 2013) and BLINCS (Shook \& Marian, 2013), the two most recent computational models of bilingual lexical development, which make predictions about the role of dominance, and to some extent, language distance, on word-to-word activation.

Following the paradigm developed by Arias-Trejo and Plunkett (2009) for monolingual infants (see also Styles \& Plunkett, 2009, 2011), children were presented with a prime inserted at the end of a carrier sentence (e.g., 'Yesterday I saw a dog') followed, 200 ms after prime offset, by a spoken, related, target word ('chien', dog in French). Two hundred ms after the onset of target word presentation, two pictures (e.g. a dog and a bus) 
appeared side-by-side on a screen for $2500 \mathrm{~ms}$. Trials in which the prime and the target are semantically related were compared to neutral trials in which the prime (e.g. 'egg') has no associative or semantic link to the target ('dog'). Evidence of semantic priming is typically indexed by children looking longer at the depicted target in the related trials as compared to the neutral trials. Here we manipulated the language of the prime and the target, so that cross-language priming could be probed for translation equivalents (Exp1) and semantic priming (Exp2).

\section{Experiment 1}

The first experiment tested priming between translation equivalents, e.g. dog chien (French translation of dog) in 27-month-old bilingual toddlers. The main aim was to examine the direction of activation between translation equivalents (excitatory or inhibitory). The second aim was to compare forward priming (L1->L2) and backward priming ( $L 2->L 1)$, with language dominance defined by relative exposure to $L 1$ and $L 2$ or by English proficiency measures. The final aim was to examine language distance effects, where we hypothesised that languages with more phonological overlap with English, such as Dutch and German, would lead to higher levels of translation equivalent priming than languages with little phonological overlap such as Mandarin or Polish.

\section{Method}

\section{Participants}

A total of 23 children were successfully tested, aged 27;6 (from $25 ; 29$ to $28 ; 23 ; 13$ girls and 10 boys). They were all simultaneous bilinguals, with a home language Cantonese $(N=1)$, Dutch $(N=2)$, French $(N=3)$, German $(N=4)$, Italian $(N=2)$, Mandarin $(N=2)$, Polish $(N=2)$, Portuguese $(N=3)$, or Spanish $(N=4)$. All children came from comparable middle-to-higher-class families, as is typical of lab-based studies. The mean education level 
of mothers was $6.65(S D=0.6)$ and fathers $6.4(S D=1.0)$ on a scale from 1 to 7 , with 7 representing a postgraduate education. Children's average exposure to English in a typical week as measured by the Language Exposure Questionnaire (LEQ: Cattani et al., 2014) was 54.1\% (SD = 17.8). Their average English vocabulary score on the long version of the Oxford CDI (Hamilton et al., 2000) (data missing for one child) was $73.4 \%$ words out of 553 in comprehension $(S D=14.1)$ and $50.8 \%$ in production $(S D=23.3)$. Their vocabulary scores in their home language were obtained through the appropriate CDIs (see Appendix A; data missing for 5 children), and given that they all vary in length (Cantonese: 389 words; Dutch: 444 words; French: 415 words; German: 600 words; Italian: 413 words; Mandarin: 411 words; Polish: 381 words; Portuguese: 90 words; Spanish: 594), we calculated vocabulary scores as a proportion of total words (these data are missing for 4 children). The resulting average vocabulary score in the home language was $79.2 \%$ in comprehension (SD = 17.6) and $47.3 \%$ in production $(S D=32.8)$.

The data of an additional group of 9 toddlers were discarded because of insufficient vocabulary knowledge ( $N=8$; see result section) and failure to engage in the task $(N=1)$.

\section{Evaluating dominance}

To analyse priming data as a function of language dominance, we classified children as English or Home Language ( $\mathrm{HL}$ ) dominant using two different estimates: either their relative amount of exposure to English versus the $\mathrm{HL}$, or their level of vocabulary knowledge in English. Note that the amount of exposure significantly predicted the English CDI comprehension scores $(r=0.38, p=.039$, one-tailed), but less so English production $(r=$ $0.32, p=.074$, one-tailed). The amount of exposure to English did also predict (negatively) vocabulary scores in the Home Language CDIs in comprehension $(r=-.54, p=.01$, onetailed) and production ( $r=-.45, p=.03$, one-tailed). 
Using the amount of exposure to English, children were grouped as English dominant $(\mathrm{N}=12)$ if they had $50 \%$ or more exposure to English, and as $\mathrm{HL}$ dominant otherwise $(\mathrm{N}=11)$. As expected, the English dominant children had higher vocabulary in English than the $\mathrm{HL}$ dominant children in comprehension (respectively $M=79.4$ versus 67.4) and production (respectively $M=59.5$ versus 42.2 ) which was significant for comprehension $(\mathrm{t}(20)=2.15, \mathrm{p}=.044)$ but not for production $(\mathrm{t}(20)=1.84, \mathrm{p}=.081)$. For HL vocabulary scores, HL dominant children understood and produced about the same number of words $(M=85.5 \%$ and $M=51.8 \%)$ as English dominant children $(M=74.1 \% ; M=$ 43.7\%; all t $(16)<1.41)$.

Using the English vocabulary scores (one missing data), we grouped children in the English dominant group ( $N=11$ ) if they scored above the group median in English in comprehension and production and in the $\mathrm{HL}$ group otherwise $(\mathrm{N}=11)$. For the majority of children $(\mathrm{N}=15)$, the two scores - comprehension and production - converged to predict the dominance group; for the remaining 8 children, we used comprehension scores to assign them to a dominance group.

The two indices of dominance (amount of exposure and vocabulary scores) did not match (simple matching coefficient: 0.64 ; this is the number of converging scores divided by the total number of scores). Distributions of LEQ and CDI scores are provided in Figure 1.

Insert Figure 1 here

\section{Evaluating language distance}

Pairs of languages (English / Home Language) were given a score of distance using a metric of phonological overlap of translation equivalents (Floccia et al., 2018). This toddler- 
centric measure of language distance was developed from translation equivalents of the non-onomatopoeic words from the Oxford CDI, phonemically transcribed in British English and 13 languages. The overlap between each English word and its translation equivalent was calculated as the Levenshtein distance, that is, the smallest number of alterations needed to transform one word to its translation. This measure was then normalised by word length to produce a value between 0 (no overlap) and 1 (cognate), then averaged across words. In this metric, the closest language to English is Dutch $(0.2214)$, followed by German (0.1975), Italian (0.1076), French (0.1034), Spanish (0.0874), Polish (0.0828), Portuguese (0.0801), Cantonese (0.0422) and Mandarin (0.0197). This measure will be used as a covariate in subsequent analyses.

Stimuli

In each related trial, the prime was presented in a carrier sentence, e.g. "Yesterday I saw some cheese", followed by the target word, e.g. "fromage" (French translation of cheese). Then two images were presented side by side, e.g. the target image (cheese) and a distracter (e.g. a doll). In the unrelated condition, the prime would be for example the word sock, semantically unrelated to the target fromage (cheese).

In each language pair (e.g. English-French), we selected 20 triplets made of 2 words acting as target, related prime and distracter, and a third word acting as the unrelated prime, for example cheese/doll/sock. The following constraints applied to the first two words of the triplet: no phonological overlap in English, between the two translations (e.g. fromage and poupée in French), nor between the English words and their translations (no cognates). The corresponding unrelated prime (here, sock and chaussette in French) was chosen so that it would not be a cognate, and would not share its initial phoneme with the target and distracter in the other language (chaussette doesn't share its onset with fromage 
or poupée). It must be noted that animal target words were systematically paired with another animal distracter word ( $25 \%$ of trials), to avoid a ceiling effect for images of animated objects that we had observed in prior studies. Arias-Trejo and Plunkett (2010) have shown that competition between target and distracter only occurs if the two images are taxonomically and perceptually related. Therefore, to minimise such a competition, the two animals were not perceptually related (e.g. horse and butterfly). Post-hoc analyses showed that the priming effects were similar when these trials were removed.

With these constraints, stimuli selection had to be slightly adjusted in each language: as can be seen in Appendix B, the total number of targets or distracters which had to be changed from a common initial list ranged from 0 (Mandarin) to 7 (Portuguese) out of 40 . The total number of unrelated primes which needed to be changed ranged from 0 (Mandarin) to 10 (Portuguese) out of 20. All words (in English) were known by at least $56 \%$ of English monolingual children aged 24 months according to the Oxford CDI norms (Hamilton et al., 2000).

Across children, each word from the target/distracter pair appeared equally often as a target or a distracter, and would be equally often preceded by a related prime or an unrelated prime: one child would hear the prime-target fromage (cheese in French) cheese and then see pictures of a piece of cheese and a doll (Related condition). Another child would hear poupée (doll in French) - doll and see pictures of a piece of cheese and a doll (Related condition). A third child would hear chaussette (sock in French) - cheese and a fourth child would hear chaussette - doll (Unrelated condition). This design is illustrated in Figure 2, and the total list of triplets for each language can be found in Appendix B.

Figure 2 around here 
In each language pair, four pseudo-random orders were used to create two blocks of 20 trials each. For half of the children, in the first block, the prime was in English and the target in the Home Language, with the opposite in the second block. The reverse order was used for the other half of the children. Within each block, no stimulus (word or picture) appeared more than once. However, every pair of target-distracter pictures re-appeared once in the second block, in a different condition (target became distracter) and with presentation side reversed (left/right). Within each block, no more than two consecutive trials were in the same condition (related/unrelated), and no more than two consecutive trials had the target on the same side (left/right). Two training trials were presented at the start of each block with words/pictures not used in the test set, and responses discarded from the analyses.

Stimuli were recorded by native female speakers aged between 20 and 39 . The English speaker had a standard South of England accent, the French, Italian, Spanish, Polish, Portuguese (Brazilian), German and Dutch speakers had a standard metropolitan accent in their home country, the Mandarin speaker was from Beijing and the Cantonese speaker from Hong Kong. All sound files were normalised for amplitude using Audacity, and sentences containing the prime phrase and target words (produced in isolation) were then concatenated with a 200 ms silence inserted in between.

Pictures were colourful photographs from the internet, selected to be representative of the named object according to experimenters. They were cropped and pasted to occupy the same space within a square frame, on a pale grey background. To maximise contrast, we ensured that paired images had a different, predominant colour (e.g. no orange car with an orange). 


\section{Procedure}

Once informed consent had been obtained, caregivers were sent electronically the English CDI and the Additional Language CDI prior to the day of testing. On the day of the visit, they were asked to complete a word checklist containing all words presented in the test (as spoken words and/or images), in the two languages, to indicate whether their child knew and/or produced each of them. They were also asked to fill in the Language Exposure Questionnaire (LEQ: Cattani et al., 2014) with the experimenter. The experiment started after a short warm-up play session.

The toddler was sat on their caregiver's lap approximately $65 \mathrm{~cm}$ away from the 23inch screen and the Tobii TX300 eye tracker. The caregiver was asked to close their eyes and refrain from interacting with the child during the experiment. A 9-point calibration was performed where the attention getter was either a colourful beach ball or a star. When necessary, individual points or all points were re-calibrated in order to achieve a good eye calibration. Custom eye-tracking software, PresentMate, was used to run the calibration and the experiment and record eye movement data. The Tobii eye tracker sampling rate was set to $120 \mathrm{~Hz}$. Auditory stimuli were presented through a loudspeaker located centrally just above the screen. The experimenter monitored the toddler's eye movements from an adjacent room, through a video camera also located centrally above the screen. The trials were initiated by the experimenter, by pressing a button, only if the child was looking at the screen.

Children were presented with two blocks of 20 pairs of images, one of which was the named target, and the other the unnamed distracter. At the start of each trial (the pretrial period), the participant saw a centrally located animation (which served to maintain their attention) and heard a carrier sentence ending with the prime word ('yesterday, I saw 
a doll'). The duration of the pre-trial period was 3200 ms for the French, Polish, Spanish, Portuguese, German and Dutch conditions, and 4200 ms for Italian, Cantonese and Mandarin, as sentences were on average longer in those languages. Two hundred ms after the offset of the prime, the target word began. The presentation of the two images started another $200 \mathrm{~ms}$ after the onset of the target word, and remained on screen for $2500 \mathrm{~ms}$ (the picture trial period; see Figure 2). Half the children were presented with a block of English primes followed by a block of Home Language primes, whereas the other half heard the block of Home Language primes first. It must be noted that a previous version of this experiment was run with a 0 ms SOA between the onset of the target word and the presentation of the pictures. The experiment was then re-run with a $200 \mathrm{~ms}$ SOA to equate the timing parameters of Experiment 2. Main results of this initial experiment are very similar to those of Experiment 1 and provided in Supplementary Materials.

The eye-tracking data was processed using custom MATLAB code. Eye-tracking data was considered valid if the eye-tracker validation flag indicated that at least one eye was found, the recorded gaze was within the screen area, and the recorded pupil diameter was positive and within physiological range. If data from both eyes was valid, the left eye gaze data was used in further processing. Valid gaze data was filtered with a second-order Savitsky-Golay filter with a length of 7 samples (23 ms) (Nyström \& Holmqvist, 2010). Blinks were detected as sections of the data with instantaneous rate of change of pupil diameter greater than $0.1 \mathrm{~mm}$ and the corresponding samples were flagged as invalid. The invalid data for gaze was replaced with last valid value. Fixations were defined by maximum gaze dispersion of 2 degrees of visual angle. The minimum fixation duration was set to $100 \mathrm{~ms}$. 
Trials in which the child did not know the prime and the target in the language of presentation as reported on the word checklist on the day of testing were excluded from the analyses; in addition, a trial was deemed valid if the child fixated at least one picture at some point. Children were excluded if, as a result, they had less than 16 valid trials out of 40 (see participant section; these children are referred to as having too small a vocabulary). In the final dataset of 23 children, there were an average of 29.35 valid trials per child out of $40(S D=5.6)$.

The dependent variable was the proportion of looking time towards the target (PLT), calculated as the amount of looking time towards the target divided by the total looking time towards target and distracter, in each trial. The window of analysis was $0-2000 \mathrm{~ms}$ from the onset of the target word. Inspection of the PLT time course (see Figure 6) shows that any differences between conditions are located within the first 1700 ms of test trials. Analyses of looking times, therefore, focus on this time 0-2000 ms window (Mirman, 2016). All analyses and data can be found at https://osf.io/fmvrh/?view_only=3d56304b364f484486307f4c8569efc3. Plan of analyses

In preliminary analyses, the effect of language of the prime (English versus $\mathrm{HL}$ ) and priming (related versus unrelated prime-target) as within-participant variables was examined together with order of block presentation as a between-participant variable (primes in English first versus primes in the HL first) and age (as a covariate). Then the same analyses were re-run without age and order to evaluate the effect of priming and its interaction with the language of the prime. This was followed by the co-injection of language dominance (defined either by amount of exposure, or by vocabulary scores) and language distance. Finally, we performed a time course analysis using the non-parametrical 
test developed by Maris and Oostenveld (2007) to identify the window of appearance of the priming effect.

Preliminary analyses

An initial ANOVA on PLT with language of the prime (English vs. Home Language) and priming (related vs. unrelated prime-target) as repeated measures, and order of block presentation and age (covariate) as between-participant factors, did not reveal any main effect of age $(F(1,20)=3.17, p=.090)$ or $\operatorname{order}(F(1,20)=.071, p=.79)$. No interaction was found between any of the factors (all Fs $<1.23$ ), therefore age and order were discarded from further analyses.

Effect of priming and language of the prime

In this second step, we examined the effects of priming and language of the prime, to obtain a picture of the overall behaviour of the group of toddlers and address our first research question: what is the direction of activation between translation equivalents? An ANOVA with language of the prime (English vs. Home Language) and priming (related vs. unrelated prime-target) as repeated measures was run on the proportion of looking times (PLT) towards the target (see Figure 3). A main effect of priming was found $(F(1,22)=7.83$, $\left.p=.010, \eta^{2}=.26\right)$, due to longer looking times to the target in the related condition $(61.48 \%, \mathrm{SD}=8.07 \%)$ than in the unrelated condition $(54.46 \%, \mathrm{SD}=8.41 \%)$. No effect of the language of prime was found $\left(F(1,22)=.27, p=.61, \eta^{2}=.012\right)$, as looking times to the target were comparable for a prime in English (58.59\%, SD $=7.85 \%$ ) or in the Home Language $(57.72 \%, \mathrm{SD}=7.65 \%)$. There was no interaction between priming and language of the prime $\left(F(1,22)=1.18, p=.29, \eta^{2}=.051\right)$. Given that language of the prime did not modify the priming effect, it was excluded from further analyses. 
Figure 3 around here

In summary, a strong effect of priming was found overall, independent of age or order of block presentation, and irrespective of the language of the prime (or the language of the target). This result points to a symmetry in the direction of the priming effects of the Home Language and English. It must be noted, however, that contrary to similar research with monolingual children (e.g. Arias-Trejo \& Plunkett, 2009) where target recognition appears to be blocked in the unrelated condition, bilingual children recognised the target in the unrelated condition $(54.46 \%, \mathrm{SD}=8.41 \%$, t-test against chance at $50 \%$ : $\mathrm{t}(22)=2.54, \mathrm{p}=$ $.019)$, as well as, of course, in the related condition $(61.48 \%, \mathrm{SD}=8.07 \%$; $\mathrm{t}(22)=6.82, \mathrm{p}<$ .0001). We shall return to this result in the discussion.

Effect of language distance and dominance defined through exposure

In what follows, the priming score (difference between PLT in the related condition and the unrelated condition) was used instead of the PLT measure, as we were interested in factors that could modulate priming effects more than mere looking times.

An ANOVA was conducted on priming scores with language dominance as defined through exposure as a repeated measure (prime in the dominant language versus prime in the nondominant language), and language distance as a covariate. There was no effect of language dominance $\left(F\left(1,21.25, p=.62, \eta^{2}=.01\right)\right.$ or language distance $\left(F(1,21)=1.58, p=.22, \eta^{2}=\right.$ .07), and no significant interaction $\left(F(1,21)=.09, p=.77, \eta^{2}=.004\right)$ (see an illustration of the effects of dominance on Figure 4, top panel). Reliability of these null effects were further established through a Bayesian t-test comparing priming scores for primes in the dominant language (mean 0.079, SD 0.16) versus non-dominant (mean 0.057, SD 0.14) (BF = .25 , paired $t(22)=.51, p=.61)$, which shows substantial evidence for the null hypothesis 
that language dominance does not modify priming results. The Pearson correlation between language distance and priming scores was not significant $(N=23, r=.26, p=.22)$, but a BF of 0.82 indicates an uncertainty as to whether the null hypothesis should be accepted or not. Visual inspection of the relationship between distance and priming scores actually revealed an outlier with a high priming score and a low language distance (top left corner of Figure 5). Without this outlier, the correlation reached significance ( $N=21, r=.44, p=.039)$ but the BF at 2.54 fails to reach the threshold of 3 which we would accept as a significant outcome. Bayesian statistics were calculated using the BayesFactor package (Morey \& Rouder, 2018), within the R environment (R Core Team, 2019).

\section{Effect of language distance and dominance defined through vocabulary scores}

The same analysis as above was conducted, replacing language dominance as defined through exposure with language dominance as defined through vocabulary scores. Again, there was no effect of language dominance $\left(F(1,21)=.054, p=.82, \eta^{2}=.003\right)$ or language distance $\left(F(1,21)=1.59, p=.22, \eta^{2}=.07\right)$, and no significant interaction $(F(1,21)$ $=.001, p=.98, \eta^{2}=.00$ ) (see an illustration of the effects of dominance on Figure 4, bottom panel). A Bayesian t-test comparing priming scores for primes in the dominant language (mean 0.078, SD 0.16) versus non-dominant (mean 0.058, SD 0.14) $(B F=.24$, paired $t(22)=$ $.46, p=.65$ ) shows again substantial evidence for the null hypothesis that language dominance does not modify priming results.

Insert Figure 4 here

Insert Figure 5 here 


\section{Time-course analysis}

Figure 6 shows the mean proportion of participants' fixations at the target image calculated in $8.33 \mathrm{~ms}$ epochs, for the unrelated and related prime-target conditions. The window of analysis starts at the onset of target word presentation. Visual inspection suggests that the target word recognition occurs at around $600 \mathrm{~ms}$ from target onset in the related condition, against 900 ms for the unrelated condition. To identify periods when looking behaviour differs between conditions, we used a non-parametrical test developed by Maris and Oostenveld (2007) for ERP and MEG data, and applied to preferential looking times (Von Holzen et al., 2018; Von Holzen \& Mani, 2012; Delle Luche, Durrant, Poltrock, \& Floccia, 2015). In the first step individual paired sample $t$-tests are performed at each time sample, and used to identify significant $(p<.05) t$-values. In step two, clusters are identified by finding significant $t$-values that are contiguous across time. For each such cluster, a cluster-level $t$-value is calculated as the sum of all single sample $t$-values within the cluster. Analysis thereafter is based on these clusters and their associated cluster level $t$-value, rather than the individual (and highly non-independent) $t$-values. Since cluster level $t$-values could not be tested for significance against a standard $t$ distribution, in step three of the procedure, the significance of each cluster is calculated by comparing its cluster-level $t$ value to a Monte Carlo distribution of cluster level $t$-values generated from the cluster with the largest cluster-level $t$-value.

Confirming visual inspection, it was found that the two conditions (related and unrelated) differed significantly between 692 and 1742 ms post target onset (cluster $t$ statistics $=416.42$, Monte Carlo $p=.0005)$. These data will be compared to those in 
Experiment 2 to determine whether translation equivalent priming is more robust and faster than semantic priming.

Figure 6 around here

\section{Discussion of Experiment 1}

The aims of this first experiment were to examine the direction of word activation in translation equivalent priming in bilingual toddlers, compare forward and backward priming using measures of language dominance based on exposure and proficiency, and evaluate the effect of language distance on priming.

We found clear evidence of cross-linguistic priming of translation equivalents across a range of English/Additional Language pairs, so that the presentation of a word in one of these languages would facilitate the recognition of its translation equivalent. This crosslanguage facilitation effect is similar to that reported repeatedly in the adult literature (e.g. Basnight-Brown \& Altarriba, 2007; Spivey \& Marian, 1999; Weber \& Cutler, 2004), and suggests that the inhibition results reported by Von Holzen and Mani (2012) in a covert priming paradigm are unlikely to be due to inhibition between translation equivalents, as was suggested by the authors.

Quite strikingly, the priming effect reported here was not affected by any of the factors of interest: it was not modulated by language dominance of the prime (whether dominance was assessed by exposure or English proficiency), nor was it affected by the language distance between English and the home language (measured by phono-lexical overlap). In a bilingual toddler, dog primes Hund and Hund primes dog (example from German) in a symmetrical way, supporting the view that in simultaneous bilinguals, 
concepts are accessed through an integrated parallel route. This is quite distinct from adult data in spoken word recognition, where asymmetries are common, with forward priming more robust than backward priming (e.g. Spivey \& Marian, 1999; Marian et al., 2008), or the other way round (e.g. Blumenfeld \& Marian, 2007; Weber \& Cutler, 2004). Very young bilinguals seem to grow a lexicon which is intrinsically interleaved from the start, with direct and symmetrical routes across concepts.

The locus of the facilitation effect between translation equivalents reported here is likely to be due to the combined activation of competitors through conceptual routes and lateral links. All current models of the developing bilingual lexicon agree on the existence of activation feeding through shared semantic information (e.g. DevLex-II: Zhao \& Li, 2010, 2013; BLINCS: Shook \& Marian, 2013), and to some extent, on the existence of lateral activation of translation equivalents (see DeAnda et al., 2016). Notable exceptions are the BIA (Dijkstra et al., 1998) and the BIA-d (Grainger et al., 2010), where translation equivalents are linked through lateral inhibitory connections at the word level, an idea supported by findings that increasing L2 proficiency or use can lead to an inhibition of L1 word activation (Levy, McVeigh, Marful, \& Anderson, 2007; Linck, Kroll, \& Sunderman, 2009), as a way to prevent interference. However, it is difficult to tell whether these reported inhibition effects in adults are due to a higher level inhibitory control required by increased language use, or to modified connections at the word level. As it stands, the simplest account for the nature of the links between translation equivalents, in adults and toddlers, is that of a facilitatory linkage through semantic links, with the probable contribution of word-to-word links.

In this experiment, stimuli were carefully chosen so that there would be no phonological overlap between prime, target and distracter, either within or across 
languages, so that we could evaluate the effect of language distance irrespective of any phonological overlap between the stimuli themselves. Contrary to predictions derived from our inspection of models of the bilingual lexicon, we did not observe any effect of language distance on priming. That is, children learning languages with a high degree of phono-lexical overlap such as English-German or English-Dutch showed the same effect of priming as those learning more distant languages such as English-Mandarin or English-Polish. We will return to these results in the general discussion.

\section{Cross-language semantic priming}

In the hierarchy of word overlap, cognates (bed-Bett) are more overlapping than non-cognate translation equivalents ( $\log -$ Hund), which in turn are more overlapping than semantic neighbours (dog - Katze, cat in German). A review of masked priming studies in adults by Schoonbaert et al. (2009) concluded that semantic priming is usually weaker than translation priming (it must be noted though that semantic priming studies are three times less common than translation priming studies), and that results hint towards an asymmetry as a function of dominance, with forward priming stronger than backward priming (see Basnight-Brown \& Altarriba, 2007, for a direct comparison).

The explanation behind the superiority of translation priming over semantic priming (see also Goodrich \& Lonigan, 2018, for such an effect in 7-year-olds) has two levels: first, activation of semantic neighbours is assumed to transit through semantic representations only, whereas links between translation equivalents could be due to a combination of lexical (RHM: Kroll \& Stewart, 1994; De Groot \& Nas, 1991) and semantic activation (DRM: de Groot, 1992). Second, semantic neighbours share less semantic features than translation equivalents, weakening any backwards propagation from the semantic to the lexical level. 
demonstrated stronger forward priming than backward priming in a group of 2130 -monthold Mandarin-English toddlers, using cross-linguistic semantic priming, whereas Jardak and Byers-Heinlein (2018) failed to demonstrate such an asymmetry in a group of 16 30-montholds learning French and English. Given these inconsistent and inconclusive results, Experiment 2 re-visits cross-language semantic priming in toddlers, using similar methodological features to Experiment 1, in order to directly compare the two forms of priming (translation equivalent and cross-language semantic).

First, we expected translation priming to be more robust (earlier, larger and longer lasting) than semantic priming (e.g. Basnight-Brown \& Altarriba, 2007). Second, we examined the direction of activation between semantically related words, again with the idea that asymmetries as a function of dominance would be more visible than in translation equivalent priming. Precisely, we would expect forward priming (L1->L2) to be stronger than backward priming (L2->L1). The final aim was to examine language distance effects, through lexico-phonological overlap between languages as was done in Exp 1, but also through phonological overlap between stimuli. Indeed, given the much more difficult task of selecting non-overlapping stimuli in Experiment 2 than in Experiment 1 (see stimuli section of Experiment 2), in the second experiment we decided not to attempt to control for an absence of phonological overlap between stimuli, but to examine the effect of overall language distance in addition to that of the phonological overlap in the stimuli. It must be noted that, contrary to Experiment 1, we did not expect an effect of language distance on cross-language semantic priming, as phonological overlap should mainly affect the internal structure of the lexical maps, not so much the semantic maps.

Experiment 2 
A group of 27-month-old bilingual toddlers learning British English and one of a range of home languages (identical to Experiment 1 plus Greek, but without Cantonese and Portuguese, due to recruitment opportunities) were tested in a cross-language semantic priming task, whereby they heard pairs of semantically related words such as dog-chat (French translation of cat).

\section{Method}

Participants

A total of 31 children were successfully tested, aged 27;12 months (from $25 ; 24$ to 29;14; 14 girls and 17 boys). None of these children had taken part in the first experiment. They were all simultaneous bilinguals, with a home language Dutch $(N=3)$, French $(N=4)$, German ( $N=3)$, Greek $(N=3)$, Italian $(N=3)$, Mandarin $(N=5)$, Polish $(N=5)$, or Spanish ( = 5). All children came from middle-to-higher-class families. The mean education level of mothers was $6.7(S D=0.5)$ and fathers $6.6(S D=0.7)$, on a scale from 1 to 7 , with 7 representing a postgraduate education. There was no significant effect of language background on education levels. Their average exposure to English in a typical week was 51.9\% (SD = 24.4). Their average English vocabulary score on the Oxford CDI (Hamilton et al., 2000 ) was $83.5 \%$ words in comprehension $(S D=18.1)$ and $60.6 \%$ in production $(S D=$ 26.1) (data are missing for 2 children). Their vocabulary scores in their home language were obtained through the appropriate CDIs (see Appendix A). Given that all CDIs vary in length (see Experiment 1; Greek: 654), we calculated vocabulary scores as a proportion of total words (data are missing for 2 children). The resulting average vocabulary score in the home language was $73.8 \%$ in comprehension $(S D=20.0)$ and $37.5 \%$ in production $(S D=28.6)$.

The data for an additional group of 10 toddlers were discarded because of incomplete key data sets (missing CDI data in the two languages: $N=2$ ), insufficient 
vocabulary knowledge ( $N=1$; see result section), trilingual $(N=4)$, non-completion of the experiment $(\mathrm{N}=2)$, and experimental error $(\mathrm{N}=1)$.

\section{Evaluating dominance}

As in Experiment 1, children were classified as English or Home Language dominant using either their relative amount of exposure to English versus the $\mathrm{HL}$, or their level of vocabulary knowledge in English. The amount of exposure to English significantly predicted the English CDI production scores $(r=0.388, p=.038)$, but not English comprehension $(r=$ $0.234, p=.23)$. It also correlated negatively with Home Language comprehension scores $(r=$ $-.464, p=.011)$ and production scores $(r=-.566, p=.001)$.

Using the amount of exposure, children were grouped as English dominant $(\mathrm{N}=16)$ if they had $50 \%$ or more exposure to English, and as $\mathrm{HL}$ dominant if they had less than $50 \%$ exposure to English $(\mathrm{N}=15)$. As expected, the English dominant children had higher vocabulary in English than the $\mathrm{HL}$ dominant children in comprehension (respectively $\mathrm{M}=$ $85.8 \%$ versus $80.8 \%$ ) and production (respectively $M=69.1 \%$ versus $50.2 \%$ ), which was significant for production only (t $(27)=2.05, \mathrm{p}=.050)$. For HL vocabulary scores, $\mathrm{HL}$ dominant children understood and produced more words $(\mathrm{M}=84.9 \%$ and $\mathrm{M}=51.6 \%)$ than English dominant children ( $M=63.5 \% ; M=24.4 \%)$, which was significant for comprehension (t $(27)=3.36, p=.002)$ and production $(t(27)=2.87, p=.008)$.

Using the vocabulary scores, we grouped children in the English dominant group ( $\mathrm{N}$ $=15$ ) if they scored above the group median in English in comprehension and production and in the $\mathrm{HL}$ group otherwise ( $\mathrm{N}=14$; English $\mathrm{CDI}$ data were missing for two children). For the majority of children (26), the two scores - comprehension and production - converged to predict the dominance group; for the remaining 4 children, we used comprehension scores to assign them to a dominance group. 
The two indexes of dominance (amount of exposure and vocabulary scores) did not match (simple matching coefficient: 0.57 ). The distribution of LEQ and English vocabulary scores for each dominance group can be found in Figure 7.

Insert Figure 7 here

\section{Evaluating language distance}

The metric of language distance was similar to that used in Experiment 1 (Floccia et al., 2018), with the addition of Greek (0.0807).

Stimuli

As in Experiment 1, in each related trial, the prime was presented in a carrier sentence, e.g. "Yesterday I saw a sock", followed by a related target word, e.g. "chaussure" (French translation of shoe). Then two images were presented side by side, e.g. the target image (a shoe) and a distracter (e.g. bread). In the unrelated condition, the prime would be for example the word $T V$, semantically unrelated to the target chaussure (shoe).

To design Experiment 2, we could not apply the same criteria as in Experiment 1 in terms of non-phonological overlap between words (within and across languages), without selecting an entirely new set of words for each language pair. Children's limited vocabularies encode a small number of semantically related concepts. Therefore, we decided to use exactly the same words for all language pairs, and control afterwards for the effect of phonological overlap between primes, targets and distractors.

We selected a total of 40 target words and 40 paired related prime words (e.g. table/chair), together with 20 unrelated prime words (e.g. aeroplane). These items were then yoked as quintuplets of words. For example, the related prime-target pairs table/chair 
and dog/cat would be linked, so that cat would act as the distracter image for the target chair, and chair as the distracter image for the target cat. In unrelated trials, the unrelated prime aeroplane would precede either the target chair, or the target cat. Primes and targets were produced each in a different language (e.g., English versus French or vice versa). Pairs of related words (e.g. table/chair) were taken mostly from Arias-Trejo and Plunkett (2009, 2013).

All words were known by at least $63.4 \%$ of English monolingual children aged 24 months according to the Oxford CDI norms (Hamilton et al., 2000).

Across children, each word from a target/distracter pair appeared equally often as a target or a distracter, and would be equally often preceded by a related prime or an unrelated prime. This design is illustrated in Figure 8 , and the total list of quintuplets for each language can be found in Appendix C.

Figure 8 around here

Counterbalancing and experimental design were similar to those in Experiment 1 ; in particular, two blocks of 20 trials each were created, and for half of the children, in the first block, the prime was in English and the target in the Home Language, while the reverse was the case for the second block. The reverse order was used for the other half of the children.

Within each block, no stimulus (word or picture) appeared more than once. However, every pair of target-distracter pictures re-appeared once in the second block, in a different condition (target became distracter) and with presentation side reversed (left/right). Within each block, no more than two consecutive trials were in the same condition (related/unrelated), and no more than two consecutive trials had the target on 
the same side (left/right). Two training trials were presented at the start of each block with words/pictures not used in the test set, and discarded from the analyses.

Stimuli were recorded by native female speakers aged between 20 and 48 . The English speaker had a standard South of England accent, and the French, German, Greek and Spanish speakers had a standard metropolitan accent in their home country. The Polish, Italian and Dutch speakers had a southern accent (they were respectively from Krakow, Catania and south of Holland). The Mandarin speaker was from Taiwan.

For each language pair, a total of 160 trials were constituted ( 8 possible trials for a particular quintuplet, as seen in Figure 8, times 20 quintuplets). To analyse the effect of phonological overlap, each trial was given two scores: a first score (PT Overlap) indicated the level of overlap between the prime and the target $(0=$ no overlap, $1=$ initial phoneme overlap; 2 = more than two phonemes overlap). A second score (Cognates) indicated how many of the three words in the trial (prime, target and distracter) were cognates (from 0 to 3). We used a broad definition of cognate, encompassing any words sharing at least their first phoneme (e.g. fork and its French equivalent fourchette, or biscuit and its Mandarin translation, binggān). As can be seen from Table 1, the average number of trials with a nonzero degree of overlap between the prime and the target was negligible (PT overlap, adding up cases of initial onset overlap to cases of 2 or more phonemes overlap, ranges from 2 to 10 out of 160), minimising the likelihood to observe a modulation of the semantic priming effect by some degree of phonological overlap. However, cognates varied substantially across languages; in addition, and quite predictably so, the degree of overlap between cognates (which we did not quantify) was more substantial in etymologically related languages (such as German and English) than more distant ones (such as Polish and English). Also predictably, these measures were closely related to the estimate of 
phonological distance used in Experiment 1 to calculate the impact of language distance (see Table 1). Therefore, it is possible that cognates may have an impact on semantic priming results, either because cognates have a special status overall and are processed faster (e.g. Costa, Caramazza, \& Sebastian-Galles, 2000; Von Holzen et al., 2018), or because they act like bridges between the two language networks and contribute to boost cross-language activation overall (Costa, Santesteban, \& Caño, 2005).

Insert Table 1 around here

Procedure

The procedure was identical to that used in Experiment 1, with the difference that the checklist given to the parents on the day of testing contained only the experimental words which were not present in the corresponding CDIs (this was done to reduce the time spent filling in questionnaires during the visit). As before, children were presented with two blocks of 20 pairs of images, one of which was the named target, and the other the unnamed distracter. At the start of each trial (the pre-trial period), a centrally located animated gif was displayed to maintain infant's attention while playing a carrier sentence ending with the prime word ('yesterday, I saw a table'). Two hundred ms after the offset of the prime, the target word began (e.g. chaise, chair in French), followed 200 ms after its onset by the presentation of the two images (e.g. a chair and a cat), which remained on screen for $2500 \mathrm{~ms}$ (the picture trial period; see Figure 8). The duration of the pre-trial period was set to $5000 \mathrm{~ms}$ for all languages, as we decided to use a common duration that could absorb the cross-language variations in sentence length observed in Experiment 1.

\section{$\underline{\text { Results }}$}


Trials in which the child did not know the prime and the target in the language of presentation, as reported on the complementary word checklist on the day of testing and on the CDIs, were excluded from the analyses (for the 4 children for whom only one CDI was provided, we only excluded the trials where the child did not know the prime and the target in the completed CDI, that is, we assumed that they would know the prime and target in the other language for which the CDI was missing ${ }^{2}$ ). In addition, a trial was deemed valid only if the child looked at at least one picture at some point during the trial. Children were excluded if, as a result, they had less than 16 valid trials out of 40 (only one child was excluded on that basis; see participant section; this child is referred to as having too small a vocabulary). In the final dataset of 31 children, there were an average of 32.9 valid trials per child out of $40(S D=6.2)$.

As in Experiment 1, the dependent variable was the proportion of looking time towards the target (PLT) computed on 0-2000 ms from the onset of the target word, as inspection of the PLT time course (see Figure 6) shows that differences between conditions are located from 600 to 2000 ms.

The plan of analysis is similar to that used in Experiment 1, with the addition of an examination of the effect of phonological overlap between stimuli on priming, and a final comparison between the two experiments.

\section{Preliminary analyses}

An initial ANOVA on PLT with language of the prime (English vs. $\mathrm{HL}$ ) and priming (related vs. unrelated prime-target) as repeated measures, order of block presentation as a between-participant variable, and age as a covariate, did not reveal any effect of age ( $F(1$,

\footnotetext{
${ }^{2}$ Analyses excluding these four participants yielded the same pattern of results.
} 
$\left.28)=.12, p=.73, \eta^{2}=.004\right)$ or $\operatorname{order}\left(F(1,28)=1.52, p=.23, \eta^{2}=.05\right)$. An interaction was found between language of the prime and $\operatorname{order}\left(F(1,28)=6.43, p=.017, \eta^{2}=.19\right)$, due to the children showing higher PLT in the second block (64.8\%) than the first one (61.0\%), possibly due to a learning effect. No other interactions were significant, and in particular no interaction involving priming. Therefore, age and order were discarded from further analyses.

Effect of priming and language of the prime

In an ANOVA on PLT with language of the prime (English vs. Home Language) and priming (related vs. unrelated prime-target) as repeated measures (see Figure 9), a main effect of priming was found $\left(F(1,30)=4.77, p=.037, \eta^{2}=.14\right)$, with longer looking times to the target in the related condition $(65.4 \%, S D=6.8)$ than in the unrelated condition $(60.4 \%$, $S D=8.9)$. No effect of the language of prime was found $\left(F(1,30)=.012, p=.91, \eta^{2}=.00\right)$ nor an interaction between priming and language of the prime $\left(F(1,30)=1.86, p=.18, \eta^{2}=\right.$ $.06)$.

Figure 9 around here

In summary, an effect of priming was found overall, irrespective of the language of the prime. It must be noted that similar to Experiment 1, bilingual children identified the target in all conditions depicted in Figure 9 (t-tests against chance at 50\%: all $p<=.001$ ). We shall return to this result in the discussion.

Effect of language distance and dominance defined through exposure

An ANOVA was conducted on priming scores with language dominance as defined through exposure as a repeated measure (prime in the dominant language versus prime in 
the non-dominant language), and language distance as a covariate. As in Experiment 1, language of the prime (English vs. Home Language) was not included as it had no effect in the former analyses. There was no effect of language dominance $\left(F(1,29)=.11, p=.74, \eta^{2}\right.$ $=.004)$ or language distance $\left(F(1,29)=.61, p=.44, \eta^{2}=.02\right)$, and no significant interaction $\left(F(1,29)=.88, p=.36, \eta^{2}=.03\right)$ (see an illustration on Figure 10, left panel). As in Experiment 1, reliability of these null effects were further established through a Bayesian ttest comparing priming scores for primes in the dominant language (mean 0.068, SD 0.18) versus non-dominant (mean 0.033, SD 0.15) $(B F=.29$, paired $t(30)=.96, p=.35)$, which shows substantial evidence for the null hypothesis that language dominance does not modify priming results. The Pearson correlation between language distance and priming scores was not significant $(N=31, r=-.14, p=.44)$ with a $B F$ at 0.51 indicating an uncertainty as to whether the null hypothesis should be accepted or not. Visual inspection of the relationship between distance and priming scores did not reveal any obvious outlier (Figure 11).

Effect of language distance and dominance defined through vocabulary scores

The same analysis as above was conducted, replacing language dominance as defined through exposure with language dominance as defined through vocabulary scores (language dominance could not be estimated for two children because of missing CDI data). There was no effect of language dominance $\left(F(1,27)=2.46, p=.13, \eta^{2}=.08\right)$ nor language distance $\left(F(1,27)=.55, p=.47, \eta^{2}=.02\right)$. The interaction between dominance and distance failed to reach significance $\left(F(1,27)=3.99, p=.056, \eta^{2}=.13\right)$ (see an illustration on Figure 10, right panel). A Bayesian t-test comparing priming scores for primes in the dominant language (mean 0.056, SD 0.18) versus non-dominant (mean 0.044, SD 0.17) (BF =.21, 
paired $t(28)=.28, p=.78$ ) shows substantial evidence for the null hypothesis that language dominance does not modify priming results.

Insert Figure 10 here

Insert Figure 11 here

Effect of cross-linguistic phonological overlap between stimuli

To analyse the effect of phonological overlap between stimuli, each trial was given two scores: PT Overlap indicated the level of overlap between the prime and the target, and Cognates indicated how many of the three words in the trial (prime, target and distracter) were cognates (from 0 to 3). As seen in Table 1, the number of stimuli pairs with a non-zero PT Overlap score was too small to provide a reliable comparison. Similarly, given the small number of triplets containing 2 or more cognates, we decided to recode Cognates with 0 (no cognate within the triplet) to 1 (at least one cognate). The mean number of trials per participant with no cognates was 12.7 and 20.3 trials with at least one cognate. An ANOVA with priming and cognates (0 or 1 ) as within-participant variables showed no effect of cognates $\left(F(1,30)=.75, p=.40, \eta^{2}=.02\right)$, and no interaction between priming and cognates $\left(F(1,30)=.05, p=.82, \eta^{2}=.002\right)$. Therefore, the degree of cross-linguistic overlap between the stimuli did not appear to modify the pattern of results.

Time-course analysis

Figure 6 shows the mean proportion of participants' fixations at the target image calculated on 8.33 ms epochs, for the unrelated and related prime-target conditions. The two conditions (related and unrelated) differed significantly between 691 and 1466 ms post 
target onset (cluster $t$ statistics $=285.86$, Monte Carlo $p=.0009)$. These curves and analyses suggest that the priming effect, as indexed by the difference between the related and the unrelated conditions, occurs at about the same time in the two experiments (700 ms), but lasts longer in Experiment 1.

\section{Comparison between Experiments 1 and 2}

A priming effect was computed using PLT in Related Prime Trials minus PLT in Unrelated Prime Trials, and used as the dependent variable in subsequent analyses. First, an ANOVA was conducted with dominance as defined by exposure as a within-participant factor (trials with a prime in the dominant language versus trials with a prime in the nondominant language), language distance as a covariate, and experiment ( 1 versus 2 ) as a between participant factor. No main effect or interactions were significant. Crucially, the main effect of experiment was not significant $\left(F(1,51)=0.25, p=.62, \eta^{2}=.005\right)$. Similar results were obtained when dominance as defined by vocabulary replaced dominance defined by exposure. This suggests that the magnitude of the priming effect is similar across the two experiments.

Next, mixed effects growth curve analysis (Mirman, 2014) was used to compare the time course of the priming effect in the two experiments. In preparation for the growth curve analysis, the fixation data was aggregated into $50 \mathrm{~ms}$ time bins using the eyetracking R package (Dink \& Ferguson, 2015). As the data was collected with a $120 \mathrm{~Hz}$ eye-tracker (1000ms/120), 6 frames were aggregated within each $50 \mathrm{~ms}$ time bin for each (related and unrelated) trial. This resulted in a total of 41 time bins from 0 to $2500 \mathrm{~ms}$. The time bin data was further aggregated to yield an average for each $50 \mathrm{~ms}$ time bin across the related trials and across the unrelated trials for each participant. Finally, the dependent measurement Priming Effect (a difference score) was calculated for each 50 ms time bin: related prime 
PLT minus unrelated prime PLT. As different stimuli were used in the two experiments, it is important that we examine PLT in the related prime trials in comparison to the PLT in the unrelated prime trials (baseline).

The overall time course of the priming effect was captured with a third-order (cubic) orthogonal polynomial with fixed effects of Experiment (Experiment 1: translation vs. Experiment 2: semantic) on all time terms, and participant random effects on all time terms. With orthogonal polynomials, the intercept refers to the overall average as opposed to the $y$-intercept (Mirman, 2014), which allows us to compare the average amount of priming effects within 0 to 2500 ms between the two experiments. Experiment 1 was treated as the reference (baseline) and relative parameters estimated for Experiment 2. Statistical significance ( $p$-values) for individual parameter estimates was assessed using the normal approximation (i.e., treating the t-value as a z-value). All analyses were carried out in $\mathrm{R}$ version 3.5.3 using function Imer in the Ime4 package (version 1.1-21). Table 2 shows the results of the model. The intercept term was not significant, suggesting similar levels of priming across the two experiments (supporting the outcome of the previous ANOVA). Based on visual inspection, the priming effect in Experiment 1 reaches a slightly higher peak than that in Experiment 2, suggesting that the priming effect may have been stronger and/ or lasted longer (as suggested by the cluster analysis). However, the model indicates no significant effects on the linear, quadratic and cubic time terms. This finding suggests that, when considering data from both experiments and participant random effects, there is no reliable difference in the overall amount or trends of the priming effect in the two experiments.

Insert Table 2 around here 


\section{Discussion of Experiment 2}

Cross-linguistic semantic priming was evaluated in a group of 27-month-old bilingual toddlers, whose characteristics were very close to those tested in Experiment 1 . The results demonstrate that words in one language can prime words in another language just so long as they are semantically and/or associatively related. As in Experiment 1, factors related to exposure or balance had no impact on the results, nor did linguistic distance or the presence of cognates within the stimuli set. In addition, and contrary to our predictions raised from the adult literature, there does not seem to be any reliable difference between the time course and magnitude of priming between the two experiments: in 27-month-old bilingual toddlers, cat primes chien (French for dog) as much as chat (French for cat).

\section{General Discussion}

The aim of this paper was to examine the modulation of activation across languages as a function of the degree of semantic and phonological overlap between words, in the developing bilingual lexicon. This was done through a comparison of priming between translation equivalents (Experiment 1) and cross-language semantic priming (Experiment 2) in bilingual toddlers, and an examination of the effects of language dominance and language distance, as a means to probe the structure of the early bilingual lexicon. Similarly to what is typically observed in adults (e.g. Basnight-Brown \& Altarriba, 2007), we observed both translation equivalent priming effects and cross-language semantic priming effects, but with similar onset and magnitude. In contrast to the adult literature and to Singh (2014) with 30month-olds, but in agreement with Jardak and Byers-Heinlein (2018) at 30 months, language dominance was not found to modify the direction of priming effects. Finally, no effect of 
linguistic distance between the children's two languages was found, contrary to our prediction that closer languages would elicit stronger translation equivalent priming than distant languages. These results paint a picture of an early bilingual lexicon where the two languages are closely interleaved, irrespective of contextual factors such as dominance or the phono-lexical properties of the to-be-learned languages.

In what follows, we will examine how the two most recently implemented (unsupervised neural networks) models of the developing bilingual lexicon, DevLex-II (Zhao \& Li, 2010) and BLINCS (Shook \& Marian, 2013), accommodate these results, with a focus on the timing similarities between semantic and translation equivalent priming, and the lack of effect of dominance and language distance.

How DevLex-II accounts for current data

The most important effect found in DevLex-II (Zhao \& Li, 2013) is that translation equivalent priming is always found to be faster than cross-linguistic semantic priming, with a $120 \mathrm{~ms}$ advantage for translation priming (in the early L2 learning condition), which is quite different from our data, where the onset effect was highly similar in the two conditions. In DevLex-II, this difference is explained by translation equivalent pairs sharing more semantic features than semantic pairs, but also by the progressive strengthening of lateral connections between translation equivalents on the semantic map. These lateral connections are built-in properties of the model, creating "short paths" between translation equivalents. It could be that these lateral connections develop later in young bilinguals, and/or that semantic features are not fully specified by the age of 27 months, leading to a lack of differentiation between semantic and translation equivalent priming.

Regarding priming asymmetries, DevLex-II produces stronger forward priming than backward priming for translation equivalent priming, consistent with most adult literature, 
but not with our data. However, no such asymmetry was found for semantic priming, possibly due to a floor effect; actually the overall priming effect was not significant for semantic priming, which is not what we observed.

Finally, regarding linguistic distance, although DevLex-II was only trained with two distant languages in terms of lexico-phonological overlap (English and Chinese), the most likely outcome of training the model with two closer languages would be stronger crosslanguage priming effects for close language learners, as well as a delay in word learning for children exposed to close languages as compared to distant languages. However, the data so far contradict those predictions, since no effect of language distance on priming was found in the current study, and 24-month-old close language learners were found to learn more words in their home language than distant language learners (Floccia et al., 2018).

In summary, the results from DevLex-II are partially supported by our findings: similar to the model, we found strong evidence of translation and semantic priming, and no effects of dominance in semantic priming. However we found no evidence of a modulation of priming as a function of semantic overlap, and no effect of dominance in translation priming. In addition, tentative speculations regarding the effect of linguistic distance in the model do not seem to fit the empirical data so far. It must be noted that the training of the model with two, mostly distinct, lexicons, may not represent the bilingual child's experience in a simultaneous acquisition mode, where the two languages are used in mostly overlapping contexts; this could explain why the state of the bilingual lexicon at age 27 months is not fully captured by DevLex-II predictions.

How BLINCS accounts for current data

Although not detailed in Shook and Marian (2013), BLINCS would successfully model semantic priming since semantic neighbours (e.g. road/car) were mapped closely on the 
semantic map. In addition, based on word coactivation data provided by the authors, we would expect translation equivalent priming to be stronger than semantic priming, which again runs against our data, and suggest that the bilingual lexicon at 27 months may not have reached a stable configuration where semantic features are topologically organised as in BLINCS simulations.

Despite the fact that BLINCS is a model of the simultaneous bilingual, and as such, is not designed to address predictions related to language dominance, it could be augmented by a language inhibition function that can represent dominance, and potentially reproduce asymmetries in language-switching tasks (e.g. Gollan \& Ferreira, 2009). Here we speculated that it would predict effects of dominance on priming - contrary to our data - but whether inhibition of one language system to represent dominance is a correct representation of the early bilingual child's experience remains uncertain, as we will discuss below.

In terms of language distance, the model achieved a reasonable separation on the phono-lexical map, with distinct islands of language-specific words, when trained in English and Spanish. Effects of language distance with other pairs of languages could translate in different degrees of separation on the low-level map according to the degree of phonotactic or phonological overlap between the two languages. It could also be that language distance would modify the time needed to reach a stable state of separation, with more time needed to stabilise close languages, again running against the findings that children learning close languages know more words in their home language than children learning distant languages (Floccia et al., 2018).

In summary, BLINCS correctly predicts translation equivalent priming, but presumably predicts an earlier translation priming effect than semantic priming, and effects of dominance or linguistic distance, although it must be noted that none of these particular 
effects were tested by Shook and Marian (2013).

The initial bilingual lexicon

It is clear from the discussion so far that the most recent models of bilingual acquisition predict that both translation and semantic priming occur in development, but they fail to capture the overall pattern of data observed for toddlers in the current study, in terms of similarity of translation priming and semantic priming, and the absence of dominance effects (Von Holzen \& Mani, 2012; Jardak \& Byers-Heinlein 2018; see however Singh, 2014, who reported an effect of dominance on semantic priming). They also predict effects of language distance which were not uncovered here (only a weak trend was found in Experiment 1 for distant languages to produce larger priming effects). What do our results teach us about the primary architecture of the bilingual lexicon?

The finding that semantic and translation priming occur simultaneously and with the same order of magnitude in toddlers stands in sharp contrast with what is typically reported in the adult literature (Goodrich \& Lonigan, 2018; see the review by Schoonbaert et al., 2009). The advantage of translation priming, demonstrated in DevLex-II and hinted at in BLINCS, is mainly accounted for by semantic neighbours sharing fewer semantic features than translation equivalents, weakening any backwards propagation from the semantic to the lexical level. This is based of course on the assumption that semantic features are firmly established when running the models, allowing a topological organisation to emerge during the learning process. It could be however that 27-month-old bilingual toddlers' semantic features are not fully mature for such an aggregation to emerge. In other words, a dog and a chien (French for dog) might not share the same number of semantic features as we expect them to do across languages (for most words), especially if they have been learned in different contexts. This would explain why translation equivalent priming and semantic 
priming operate on the same temporal scale at that age. It would be interesting to compare how this varies for toddlers who are exposed to the two languages in clearly differentiated contexts (e.g. French only spoken at home and English only in nursery) versus those who hear the two languages in a more integrated context (e.g. French and English spoken at home). Predictions would be that an advantage of translation equivalent priming over semantic priming would emerge earlier in the latter than in the former cases.

The absence of a dominance effect is probably the most difficult result to explain. It must be said however that neither DevLex-II nor BLINCS adequately simulate a dominance imbalance in simultaneous bilinguals. DevLex-II (Zhao and Li, 2010, 2013) uses sequential learning to model early, delayed and late bilingualism, whereas Shook and Marian (2013) suggest that dominance could be simulated by introducing an inhibition function in the model, to limit activation to one language network. This latter suggestion would probably mimic what may happen when the bilingual child is placed in a situation of having to use one language only, but does not seem adequate to represent the fact that one language has reached a more mature state than the other. A more representative implementation of dominance in simultaneous acquisition would be a training set skewed towards one of the two languages, yet with words from each language randomly interleaved. Added to the fact that dominance effects in the early years are volatile (found in Singh, 2014; not found here nor in Jardak \& Byers-Heinlein, 2018), this points to the necessity of future research to describe and understand the role of language dominance in the early lexicon. One way forward would be to consider the criteria used to define young participants' bilingualism: they are usually based on measures of exposure, therefore of dominance, and they vary from one study to the next. Singh (2013) and Jardak and Byers-Heinlein (2018) only included participants with at least $25 \%$ of exposure to each language, whereas we did not apply any 
criterion - apart from the fact that parents reported that their children were raised bilingually, which was then quantified with the LEQ. It is possible, yet counterintuitive, that narrowing the distribution of exposure values contributes to enhance the observation of a dominance effect (although that would apply only to Singh, 2013). Another way forward would be to compare toddlers acquiring their two languages simultaneously from birth (as in Jardak \& Heinlein, 2018; Singh, 2013; and here) to young sequential learners. That would help to determine if the recurrent advantage of forward priming found in older children and adults is a developmental outcome due to the differential usage of each language over a few years, or whether it is caused by a different architecture in simultaneous and sequential learners from the onset of lexical learning.

Regarding language distance, it could be that in the early stages of lexical processing, language distance would play a role not so much in semantic-driven activation between words (as in translation equivalent or semantic priming), but in phonological priming. That is, unrelated phonological neighbours could be more active in close languages like French and English than in distant languages, such as bee and lit (/li/, bed in French). This might explain why 2-year-olds learn more words in their home language if their two languages are close (Floccia et al., 2018), as well as stronger covert priming through translation, as tested in Von Holzen and Mani (2012), where leg primes Stein (stone in German) through the activation of Bein, the translation equivalent of leg and a phonological neighbour of Stein. Again, data on cross-linguistic phonological priming are needed to identify the locus of the effect of linguistic distance in the early lexicon, as seen in Floccia et al. (2018).

An unexpected, yet robust, finding in these two experiments is that children reliably identified the target image in the unrelated conditions (e.g. Yesterday I saw a bus followed by Hund - dog in German), suggesting a facilitatory semantic priming effect. Such a result 
stands in sharp contrast to what has been reported in monolingual toddlers. A semantic priming effect emerges at around 21 months in monolingual toddlers. Monolingual toddlers younger than 21 months show no priming effect: they show a similar amount of target looking in the related and unrelated prime conditions. In contrast, monolingual toddlers aged 21 months or older show an inhibitory semantic priming effect, failing to reliably identify the target in unrelated conditions (Arias-Trejo \& Plunkett, 2009, 2013; Styles \& Plunkett, 2009). That is, upon hearing Yesterday, I saw a bus followed by dog, monolingual toddlers would not look longer at the target picture of a dog than at a distracter image, as if the unrelated prime bus blocked the recognition of the target dog. More recently, Chow et al. (2018) reported that monolingual 18-month-olds demonstrate an inhibitory semantic priming effect only if they have a large enough vocabulary (comparable size to 24-montholds). The emergence of an inhibitory semantic priming effect in toddlers has been attributed to the accelerating growth of the lexicon during the second part of the second year of life, calling for an optimizing principle in the suppression of competitors (Arias-Trejo \& Plunkett, 2009; Chow et al., 2018). Why was this effect not observed in 27-month-old bilingual toddlers? First, it must be noted that Jardak and Byers-Heinlein (2018) made a similar observation in 24-month-old bilinguals (in within-language priming), but at 30 months, both they and Singh (2013) did observe an inhibition effect in unrelated word pairs in 30-month-old bilinguals in cross-linguistic priming, similar to what we would expect in monolingual toddlers much earlier on. A first explanation could be that, because bilingual toddlers' vocabulary size in each language is slightly behind that of monolinguals (e.g. Bialystok et al., 2010), 27-month-olds should be compared to monolinguals even younger than 21 months of age. However, as mentioned above, 18-month-old monolinguals do not behave like our bilingual group either: they do not show any priming effect, but look longer 
at target images in both related and unrelated conditions (Arias-Trejo \& Plunkett, 2009), suggesting that inhibition between unrelated words has not developed yet. Therefore, another possibility is that the inhibition effect observed in monolinguals from the age of 21 months is specific to within-language word-to-word interactions, and does not hold for between-language activation in bilingual toddlers. If this is correct, one would expect to observe the same inhibition effect in unrelated pairs in bilinguals at 27 months, in a withinlanguage situation, a prediction which we are currently investigating.

In summary, we reported in two closely designed experiments that 27-month-olds, learning British English and one Home Language, show evidence of translation priming and cross-language semantic priming, similar to adult findings and model predictions. However, the priming effect showed a similar time course and magnitude in the two situations, and no effect of language dominance or linguistic distance were found, suggesting that in its early state, the bilingual lexicon remarkably integrates the two incoming languages. These results do not support simulations and predictions raised by the two most recent dynamic models of bilingual acquisition (Shook \& Marian, 2013; Zhao \& Li, 2013). Rather our findings suggest that the initial state of the bilingual lexicon may not correspond to a miniature version of the adult or the older child's lexicon. Future research will be needed to uncover this initial structure, and understand the role of dominance and linguistic distance in organising the transition to an adult-like architecture. 


\section{Acknowledgements}

This research was supported by the Economic and Social Research Council (UK) [ES/K01023/1] for the project "Lexicon development in bilingual toddlers" awarded to Floccia and Plunkett. We would like to thank Samantha Durrant, Rosa Kwok, and Klara Horvath for their help in data collection. Special thanks to Aditi Lahiri and Themelis Karaminis for their help in checking our phonetic transcriptions of the stimuli, and to Jeremy Goslin for his script for the implementation of the Maris \& Oostenveld analyses. Thank you to Maria Cristina Caselli, Sonia Frota, Paul Fletcher, Jena Derakhshani Hamadani, Ewa Haman, Demetra Kati, Sophie Kern, Susana López Ornat, Magdalena Smoczyńska, Gisela Szagun, Twila Tardif, TEA Ediciones, and Inge Zink for kindly agreeing to let us use their CDI word lists. Finally, thank you to all enthusiastic families who took part in this study. 


\section{References}

Arias-Trejo, N., \& Plunkett, K. (2009). Lexical-semantic priming effects during infancy. Philosophical Transactions of the Royal Society B: Biological Sciences, 364(1536), 3633-3647.

Arias-Trejo, N., \& Plunkett, K. (2010). The effects of perceptual similarity and category membership on early word-referent identification. Journal of Experimental Child Psychology, 105(1-2), 63-80.

Arias-Trejo, N., \& Plunkett, K. (2013). What's in a link: Associative and taxonomic priming effects in the infant lexicon. Cognition, 128(2), 214-227.

Basnight-Brown, D. M., \& Altarriba, J. (2007). Differences in semantic and translation priming across languages: The role of language direction and language dominance. Memory \& Cognition, 35(5), 953-965.

Bialystok, E., Luk, G., Peets, K. F., \& Yang, S. (2010). Receptive vocabulary differences in monolingual and bilingual children. Bilingualism: Language and Cognition, 13(4), $525-531$.

Bilson, S., Yoshida, H., Tran, C. D., Woods, E. A., \& Hills, T. T. (2015). Semantic facilitation in bilingual first language acquisition. Cognition, 140, 122-134.

Blumenfeld, H. K., \& Marian, V. (2007). Constraints on parallel activation in bilingual spoken language processing: Examining proficiency and lexical status using eyetracking. Language and Cognitive Processes, 22(5), 633-660.

Byers-Heinlein, K. (2014). Languages as categories: Reframing the "one language or two" question in early bilingual development. Language Learning, 64(s2), 184-201. 
Cattani, A., Abbot-Smith, K., Farag, R., Krott, A., Arreckx, F., Dennis, I., \& Floccia, C. (2014). How much exposure to English is necessary for a bilingual toddler to perform like a monolingual peer in language tests? International Journal of Language \& Communication Disorders, 49(6), 649-671.

Chen, P., Bobb, S. C., Hoshino, N., \& Marian, V. (2017). Neural signatures of language coactivation and control in bilingual spoken word comprehension. Brain Research, $1665,50-64$.

Chen, P., \& Marian, V. (2016). Bilingual spoken word recognition. In G. Gaskell and J. Mirković (Eds). Speech Perception and Spoken Word Recognition, 143-163.

Chow, J., Aimola Davies, A. M., Fuentes, L. J., \& Plunkett, K. (2016). Backward semantic inhibition in toddlers. Psychological Science, 27(10), 1312-1320.

Chow, J., Aimola Davies, A. M., Fuentes, L. J., \& Plunkett, K. (2018). The vocabulary spurt predicts the emergence of backward semantic inhibition in 18-month-old toddlers. Developmental Science, e12754.

Colomé, À., \& Miozzo, M. (2010). Which words are activated during bilingual word production? Journal of Experimental Psychology: Learning, Memory, and Cognition, 36(1), 96-109.

Costa, A., Caramazza, A., \& Sebastian-Galles, N. (2000). The cognate facilitation effect: implications for models of lexical access. Journal of Experimental Psychology: Learning, Memory, and Cognition, 26(5), 1283-1296.

Costa, A., Santesteban, M., \& Caño, A. (2005). On the facilitatory effects of cognate words in bilingual speech production. Brain and Language, 94(1), 94-103. doi:10.1016/j.bandl.2004.12.002 
Curtin, S., Byers-Heinlein, K., \& Werker, J. F. (2011). Bilingual beginnings as a lens for theory development: PRIMIR in focus. Journal of Phonetics, 39(4), 492-504.

DeAnda, S., Poulin-Dubois, D., Zesiger, P., \& Friend, M. (2016). Lexical processing and organization in bilingual first language acquisition: Guiding future research. Psychological Bulletin, 142(6), 655-667.

De Groot, A. M. (1992). Determinants of word translation. Journal of Experimental Psychology: Learning, Memory, and Cognition, 18(5), 1001-1018.

De Groot, A. M., \& Nas, G. L. (1991). Lexical representation of cognates and noncognates in compound bilinguals. Journal of Memory and Language, 30(1), 90-123.

De Houwer, A., Bornstein, M. H., \& Putnick, D. L. (2014). A bilingual-monolingual comparison of young children's vocabulary size: Evidence from comprehension and production. Applied Psycholinguistics, 35(6), 1189-1211.

Delle Luche, C., Durrant, S., Floccia, C., \& Plunkett, K. (2014). Implicit meaning in 18-monthold toddlers. Developmental Science, 17(6), 948-955.

Delle Luche, C., Durrant, S., Poltrock, S., \& Floccia, C. (2015). A methodological investigation of the intermodal preferential looking paradigm: methods of analyses, picture selection and data rejection criteria. Infant Behavior and Development, 40, 151-172.

Dijkstra, T., Van Heuven, W. J., \& Grainger, J. (1998). Simulating cross-language competition with the bilingual interactive activation model. Psychologica Belgica, 38(3-4), 177196.

Dink, J. W., \& Ferguson, B. (2015). eyetrackingR: An R library for eye-tracking data analysis. Retrieved from www.eyetracking-r.com 
Duyck, W. (2005). Translation and associative priming with cross-lingual pseudohomophones: Evidence for nonselective phonological activation in bilinguals. Journal of Experimental Psychology: Learning, Memory, and Cognition, 31(6), 1340-1359.

Duyck, W., \& Brysbaert, M. (2004). Forward and backward number translation requires conceptual mediation in both balanced and unbalanced bilinguals. Journal of Experimental Psychology: Human Perception and Performance, 30(5), 889-906.

Finkbeiner, M., Forster, K., Nicol, J., \& Nakamura, K. (2004). The role of polysemy in masked semantic and translation priming. Journal of Memory and Language, 51(1), 1-22.

Floccia, C., Sambrook, T. D., Delle Luche, C., Kwok, R., Goslin, J., White, L., Cattani, A., Sullivan, E., Abbot-Smith, K., Krott, A., Mills, D., Rowland, C., Gervain, J., \& Plunkett, K. (2018). Vocabulary of 2-year-olds learning English and an Additional Language: Norms and effects of linguistic distance. Monographs of the Society for Research in Child Development, 83(1), 1-135

Genesee, F., Nicoladis, E., \& Paradis, J. (1995). Language differentiation in early bilingual development. Journal of Child Language, 22(3), 611-631.

Gollan, T. H., \& Ferreira, V. S. (2009). Should I stay or should I switch? A cost-benefit analysis of voluntary language switching in young and aging bilinguals. Journal of Experimental Psychology: Learning, Memory, and Cognition, 35(3), 640-665.

Goodrich, J. M., \& Lonigan, C. J. (2018). Language-minority children's sensitivity to the semantic relations between words. Journal of Experimental Child Psychology, 167, 259-277.

Grainger, J., Midgley, K., \& Holcomb, P. J. (2010). Re-thinking the bilingual interactiveactivation model from a developmental perspective (BIA-d). In M. Kail \& M. Hickman 
(Eds.): Language acquisition across linguistic and cognitive systems. John Benjamins Publishing, pp 267-283.

Gross, M., Buac, M., \& Kaushanskaya, M. (2014). Conceptual scoring of receptive and expressive vocabulary measures in simultaneous and sequential bilingual children. American Journal of Speech-Language Pathology, 23(4), 574-586.

Hamilton, A., Plunkett, K., \& Schafer, G. (2000). Infant vocabulary development assessed with a British communicative development inventory. Journal of Child Language, 27(3), 689-705.

Havy, M., Bouchon, C., \& Nazzi, T. (2016). Phonetic processing when learning words: The case of bilingual infants. International Journal of Behavioral Development, 40(1), 4152.

Hills, T. T., Maouene, M., Maouene, J., Sheya, A., \& Smith, L. (2009). Longitudinal analysis of early semantic networks: Preferential attachment or preferential acquisition? Psychological Science, 20(6), 729-739.

Hoff, E. (2013). Language development, $5^{\text {th }}$ edition. Wadsworth: Cengage Learning Hoff, E., Core, C., Place, S., Rumiche, R., Señor, M., \& Parra, M. (2012). Dual language exposure and early bilingual development. Journal of Child Language, 39(1), 1-27. Ivanova, I., \& Costa, A. (2008). Does bilingualism hamper lexical access in speech production? Acta Psychologica, 127(2), 277-288.

Jardak, A., \& Byers-Heinlein, K. (2018). Labels or concepts? The development of semantic networks in bilingual two-year-olds. Child Development. https://doi.org/10.1111/cdev.13050 
Jared, D., \& Kroll, J. F. (2001). Do bilinguals activate phonological representations in one or both of their languages when naming words? Journal of Memory and Language, 44(1), 2-31.

Ju, M., \& Luce, P. A. (2004). Falling on sensitive ears: Constraints on bilingual lexical activation. Psychological Science, 15(5), 314-318.

Kroll, J. F., \& Stewart, E. (1994). Category interference in translation and picture naming: Evidence for asymmetric connections between bilingual memory representations. Journal of Memory and Language, 33(2), 149-174.

Kroll, J. F., Van Hell, J. G., Tokowicz, N., \& Green, D. W. (2010). The Revised Hierarchical Model: A critical review and assessment. Bilingualism: Language and Cognition, 13(3), 373-381.

Levy, B. J., McVeigh, N. D., Marful, A., \& Anderson, M. C. (2007). Inhibiting your native language: The role of retrieval-induced forgetting during second-language acquisition. Psychological Science, 18(1), 29-34.

Li, P., \& Farkas, I. (2002). A self-organizing connectionist model of bilingual processing. In R. Heredia and J. Altarriba (Eds.): Bilingual sentence processing. North-Holland: Elsevier Science, 59-85.

Li, P., Farkas, I., \& MacWhinney, B. (2004). Early lexical development in a self-organizing neural network. Neural networks, 17(8-9), 1345-1362.

Linck, J. A., Kroll, J. F., \& Sunderman, G. (2009). Losing access to the native language while immersed in a second language: Evidence for the role of inhibition in secondlanguage learning. Psychological Science, 20(12), 1507-1515.

Mani, N., Durrant, S., \& Floccia, C. (2012). Activation of phonological and semantic codes in toddlers. Journal of Memory and Language, 66(4), 612-622. 
Marian, V., Blumenfeld, H. K., \& Boukrina, O. V. (2008). Sensitivity to phonological similarity within and across languages. Journal of Psycholinguistic Research, 37(3), 141-170.

Marian, V., \& Spivey, M. (2003a). Competing activation in bilingual language processing: Within-and between-language competition. Bilingualism: Language and Cognition, 6(2), 97-115.

Marian, V., \& Spivey, M. (2003b). Bilingual and monolingual processing of competing lexical items. Applied Psycholinguistics, 24(2), 173-193.

Maris, E., \& Oostenveld, R. (2007). Nonparametric statistical testing of EEG-and MEGdata. Journal of Neuroscience Methods, 164(1), 177-190.

McClelland, J. L., \& Elman, J. L. (1986). The TRACE model of speech perception. Cognitive Psychology, 18(1), 1-86.

Mills, D. L., Plunkett, K., Prat, C., \& Schafer, G. (2005). Watching the infant brain learn words: Effects of vocabulary size and experience. Cognitive Development, 20(1), 19-31.

Mirman, D. (2016). Growth curve analysis and visualization using R. CRC Press.

Morey, R. D., \& Rouder, J. N. (2018). BayesFactor: Computation of Bayes Factors for Common Designs. R package version 0.9.12-4.2. https://CRAN.Rproject.org/package=BayesFactor

Norris, D. (1994). Shortlist: A connectionist model of continuous speech recognition. Cognition, 52(3), 189-234.

Nyström, M., \& Holmqvist, K. (2010). An adaptive algorithm for fixation, saccade, and glissade detection in eyetracking data. Behavioral Research Methods, 42(1), 188$204, \underline{10.3758 / B R M .42 .1 .188}$

Oller, D. K., \& Eilers, R. E. (Eds.). (2002). Language and literacy in bilingual children (Vol. 2). Clevedon: Multilingual Matters Ltd. 
Pearson, B. Z., Fernández, S., \& Oller, D. K. (1995). Cross-language synonyms in the lexicons of bilingual infants: One language or two? Journal of Child Language, 22(2), 345-368.

Poulin-dubois,D. \& Kuzyk, O., Legacy, J., Zesiger, P., \& Friend, M. (2017). Translation equivalents facilitate lexical access in very young bilinguals. Bilingualism: Language and Cognition. 1-11. 10.1017/S1366728917000657.

Radeau, M., Morais, J., \& Segui, J. (1995). Phonological priming between monosyllabic spoken words. Journal of Experimental Psychology: Human Perception and Performance, 21(6), 1297-1311.

R Core Team (2019). R: A language and environment for statistical computing. R Foundation for Statistical Computing, Vienna, Austria. URL https://www.R-project.org/.

Schoonbaert, S., Duyck, W., Brysbaert, M., \& Hartsuiker, R. J. (2009). Semantic and translation priming from a first language to a second and back: Making sense of the findings. Memory \& Cognition, 37(5), 569-586.

Shook, A., \& Marian, V. (2013). The bilingual language interaction network for comprehension of speech. Bilingualism: Language and Cognition, 16(2), 304-324.

Shook, A., \&7 Marian, V. (2017). Covert co-activation of bilinguals' non-target language: Phonological competition from translations. Linguistic Approaches to Bilingualism. http://dx.doi.org/10.1075/lab.17022.sho

Singh, L. (2014). One world, two languages: Cross-language semantic priming in bilingual toddlers. Child Development, 85(2), 755-766.

Spivey, M. J., \& Marian, V. (1999). Cross talk between native and second languages: Partial activation of an irrelevant lexicon. Psychological Science, 10(3), 281-284.

Styles, S. J., \& Plunkett, K. (2009). How do infants build a semantic system? Language and Cognition, 1(1), 1-24. 
Styles, S., \& Plunkett, K. (2011). Early links in the early lexicon: Semantically related wordpairs prime picture looking in the second year. In M. G. Gaskell \& P. Zwitserlood (Eds.): Lexical representation: A multidisciplinary approach. Walter de Gruyter, 5188.

Thordardottir, E., Rothenberg, A., Rivard, M. -E., \& Naves, R. (2006). Bilingual assessment: Can overall proficiency be estimated from separate measurement of two languages? Journal of Multilingual Communication Disorders, 4(1), 1-21. doi:10.1080/14769670500215647

Unsworth, S. (2012). Quantity-oriented and quality-oriented exposure variables in simultaneous bilingual acquisition. In Papers of the Anéla 2012 Applied Linguistics Conference (p. 13). Eburon Uitgeverij BV.

Van Hell, J. G., \& Dijkstra, T. (2002). Foreign language knowledge can influence native language performance in exclusively native contexts. Psychonomic Bulletin \& Review, 9(4), 780-789.

Vihman, M. M., Thierry, G., Lum, J., Keren-Portnoy, T., \& Martin, P. (2007). Onset of word form recognition in English, Welsh, and English-Welsh bilingual infants. Applied Psycholinguistics, 28(3), 475-493.

Volterra, V., \& Taeschner, T. (1978). The acquisition and development of language by bilingual children. Journal of Child Language, 5(2), 311-326.

Von Holzen, K., Fennell, C. T., \& Mani, N. (2018). The impact of cross-language phonological overlap on bilingual and monolingual toddlers' word recognition. Bilingualism: Language and Cognition, 1-24. doi:10.1017/S1366728918000597

Von Holzen, K., \& Mani, N. (2012). Language nonselective lexical access in bilingual toddlers. Journal of Experimental Child Psychology, 113(4), 569-586. 
Weber, A., \& Cutler, A. (2004). Lexical competition in non-native spoken-word recognition. Journal of Memory and Language, 50(1), 1-25.

Zhao, X., \& Li, P. (2007, January). Bilingual lexical representation in a self-organizing neural network model. In Proceedings of the Annual Meeting of the Cognitive Science Society (Vol. 29, No. 29).

Zhao, X., \& Li, P. (2010). Bilingual lexical interactions in an unsupervised neural network model. International Journal of Bilingual Education and Bilingualism, 13(5), 505-524.

Zhao, X., \& Li, P. (2013). Simulating cross-language priming with a dynamic computational model of the lexicon. Bilingualism: Language and Cognition, 16(2), 288-303. 
Table 1. Degree of phonological overlap between primes and targets in Experiment 2

\begin{tabular}{lcccccccc}
\hline & Dutch & German & Italian & French & Spanish & Polish & Greek & Mandarin \\
\hline PT overlap & & & & & & & & \\
No overlap & 153 & 150 & 154 & 154 & 157 & 158 & 154 & 151 \\
Initial onset & 7 & 8 & 5 & 4 & 2 & 1 & 4 & 9 \\
Two phon+ & 0 & 2 & 1 & 2 & 1 & 1 & 2 & 0 \\
Cognates & & & & & & & & \\
0 & 14 & 38 & 24 & 44 & 56 & 60 & 74 & 132 \\
1 & 66 & 76 & 98 & 80 & 72 & 84 & 56 & 28 \\
2 & 60 & 32 & 38 & 32 & 30 & 16 & 28 & 0 \\
3 & 20 & 14 & 0 & 4 & 2 & 0 & 2 & 0 \\
Phon & & & & & & & & \\
overlap & 0.2214 & 0.1975 & 0.1076 & 0.1034 & 0.0874 & 0.0828 & 0.0807 & 0.0197 \\
\hline
\end{tabular}

Note: For each English-Home Language pair, out of the 160 prime-target-distracter triplets created for Experiment 2, PT Overlap is the number of prime-target pairs that overlap (no overlap, initial onset overlap, overlap by two phonemes or more). For example, in English and German, the pair cake/Keks (meaning biscuit) overlaps by 3 phonemes. Cognates is the number of cognate words in each of the 160 prime-target-distracter triplets. For example, a triplet where all words are cognates in English and German is moon/sun/foot, or Mond/Sonne/Fuß. The last row (Phon overlap) provides the measure of phonological distance between British English and the Home Language, estimated by normalised Levenshtein distance between translation equivalents (Floccia et al., 2018). 
Table 2. Results of the Growth Curve Analysis

\begin{tabular}{lcccc}
\hline & Estimate & SE & $z$ & $p$ \\
\hline Exp 2: Intercept & 0.01 & 0.03 & 0.21 & 0.84 \\
Exp2: Linear & -0.21 & 0.12 & 1.67 & 0.09 \\
Exp 2: Quadratic & 0.03 & 0.14 & 0.22 & 0.83 \\
Exp 2: Cubic & 0.11 & 0.11 & 1.07 & 0.28 \\
\hline
\end{tabular}


Figure 1. Experiment 1: Distribution of children's scores in LEQ (left panel) and English CDI (right panel), when divided in Home Language dominant versus English dominant. On the left panel ( $n=23), 12$ children are classified as HL dominant (blue) and 11 as English dominant (yellow) if their LEQ score is under or below 50\%. On the right panel $(n=22), 11$ children are classified as HL dominant (left) or English dominant (right) if their comprehension and production scores in English are below or above the group's median.

Figure 2. Design of Experiment 1 with examples in French: in each trial, the carrier sentence ending with the prime is presented during the $3200 \mathrm{~ms}$ pre-trial (or $4200 \mathrm{~ms}$ for Italian and Mandarin where sentences were longer). The $2500 \mathrm{~ms}$ picture trial starts after a $200 \mathrm{~ms}$ silence following the prime offset, with the presentation of the target word. The two images (the target and the distracter) appear $200 \mathrm{~ms}$ after target onset. Prime-target pairs can be related (orange) or unrelated (black); the prime can be in English and the target in the Home Language (here, French) as in the top four examples, or the other way round (bottom four). Finally, each image can be either the target or the distracter.

Figure 3. Experiment 1: priming between translation equivalents when the prime is in English (left) or in the Home Language (right). Pale grey boxes correspond to related prime and target pairs (e.g. cheese/fromage - French translation of cheese) and dark grey boxes to unrelated pairs (e.g. sock/fromage).

Figure 4. Experiment 1: translation equivalent priming effect when dominance of the prime is defined through exposure (top panel) or vocabulary knowledge (bottom panel). On each panel, the left box corresponds to the priming effect when the prime is in the dominant 
language and the right box to the prime in the non-dominant language. Priming effect is measure by the difference between PLT in related prime-target pairs (e.g. cheese/fromage - French translation of cheese) versus unrelated pairs (e.g. sock/fromage).

Figure 5. Experiment 1: Individual priming scores (PLT in the related condition minus unrelated condition) as a function of language distance (e.g. English-German is 0.1975 , and English-Cantonese is 0.0422).

Figure 6. For Experiment 1 (top) and Experiment 2 (bottom), time-course plot (in ms, with SE) of the PLT to the target for the related (blue) and unrelated (red) conditions, from the start of the picture trial. The rectangle represents the time period where the two conditions differ significantly.

Figure 7. Experiment 2: Distribution of children's scores in LEQ (left panel) and English CDI (right panel), when divided in Home Language dominant versus English dominant. On the left panel ( $n=31), 15$ children are classified as HL dominant (blue) and 16 as English dominant (yellow) if their LEQ score is under or below 50\%. On the right panel $(n=29), 14$ children are classified as HL dominant (left) or English dominant (right) if their comprehension and production scores in English are below or above the group's median.

Figure 8. Design of Experiment 2: in each trial, the carrier sentence ending with the prime is presented during the $5000 \mathrm{~ms}$ pre-trial. The $2500 \mathrm{~ms}$ picture trial starts after a $200 \mathrm{~ms}$ silence following the prime offset and $200 \mathrm{~ms}$ after the target onset, with the presentation of the target word, together with two images (the target and the distracter). Prime-target pairs can be related (orange) or unrelated (black); the prime can be in English and the target 
in the Home Language (here, French) as in the top four examples, or the other way around (bottom four). Finally, each image can be either the target or the distracter.

Figure 9. Experiment 2: semantic priming when the prime is in English (left) or in the Home Language (right). Pale grey boxes correspond to related prime and target pairs (e.g. dog/chat - French translation of cat) and dark grey boxes to unrelated pairs (e.g. aeroplane/chat).

Figure 10. Experiment 2: semantic priming effect when dominance of the prime is defined through exposure (top panel) or vocabulary knowledge (bottom panel). On each panel, the left box corresponds to the priming effect when the prime is in the dominant language and the right box to the prime in the non-dominant language. Priming effect is measured by the difference between PLT in related prime-target pairs (e.g. dog/chat - French translation of cat) versus unrelated pairs (e.g. aeroplane/chat).

Figure 11. Experiment 2: Individual priming scores (PLT in the related condition minus unrelated condition) as a function of language distance (e.g. English-German is 0.1975 , and English-Cantonese is 0.0422).

Figure 12. Time course of priming effect in the two experiments. Symbols represent the behavioural data, lines represent the significant linear estimates. A priming effect greater than zero indicates the participants looked more at the target in the related-prime trials than in the unrelated-prime trials. 


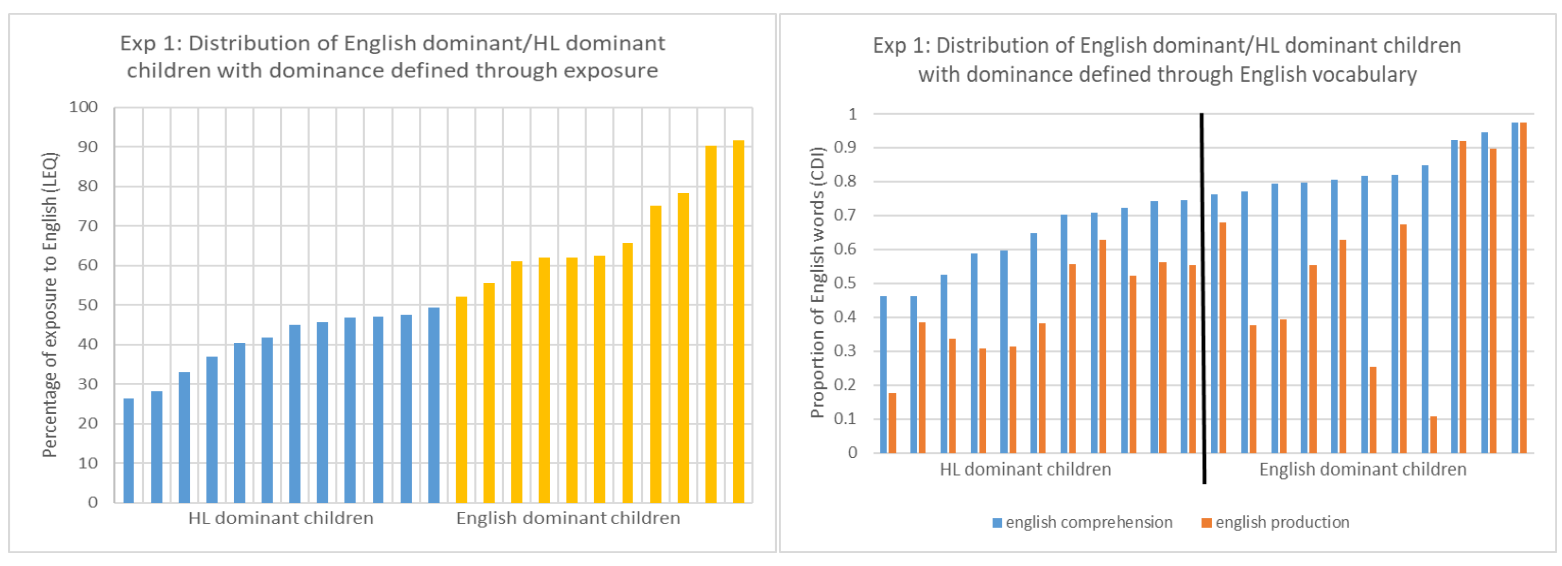

Figure 1 


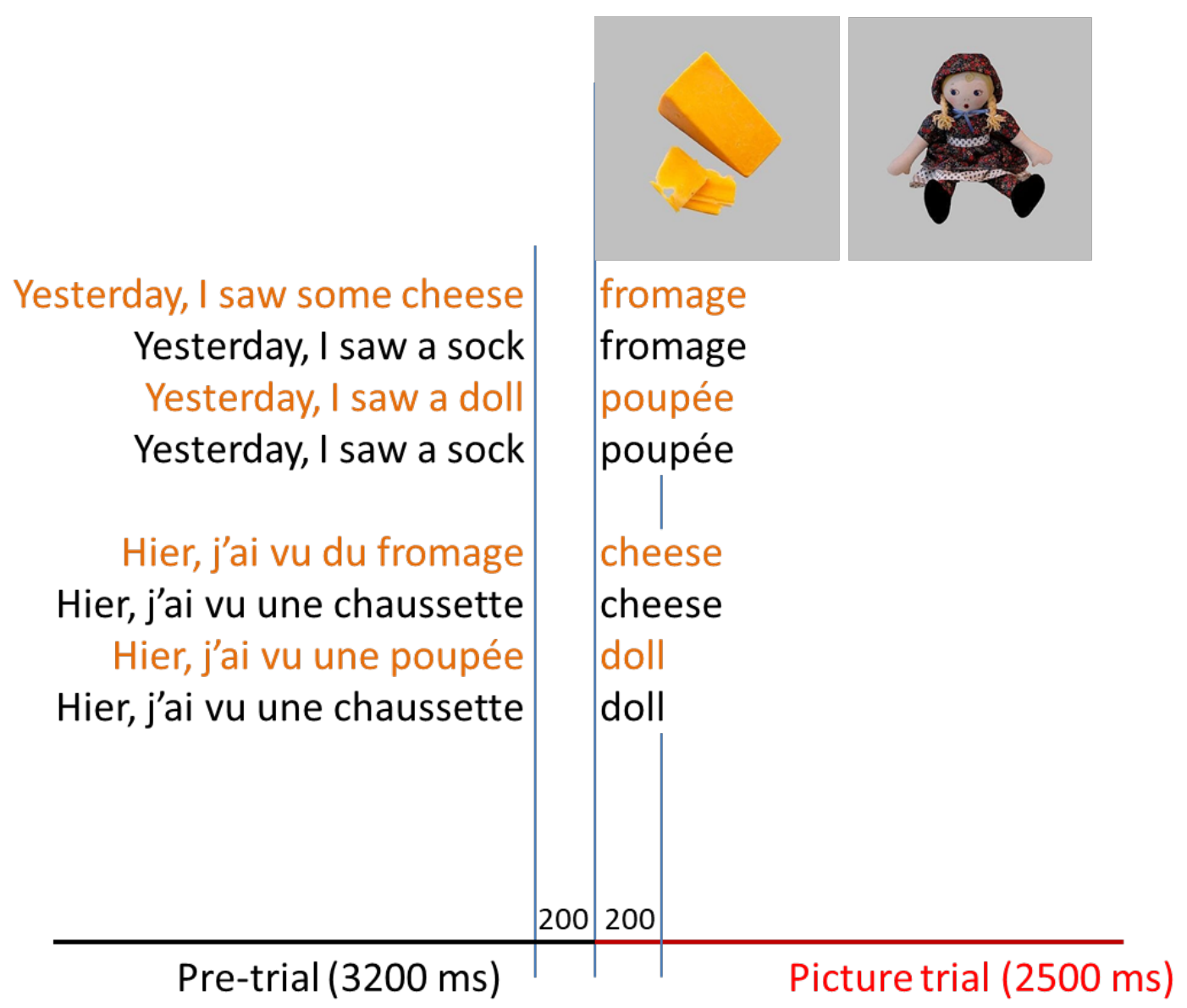

Figure 2 


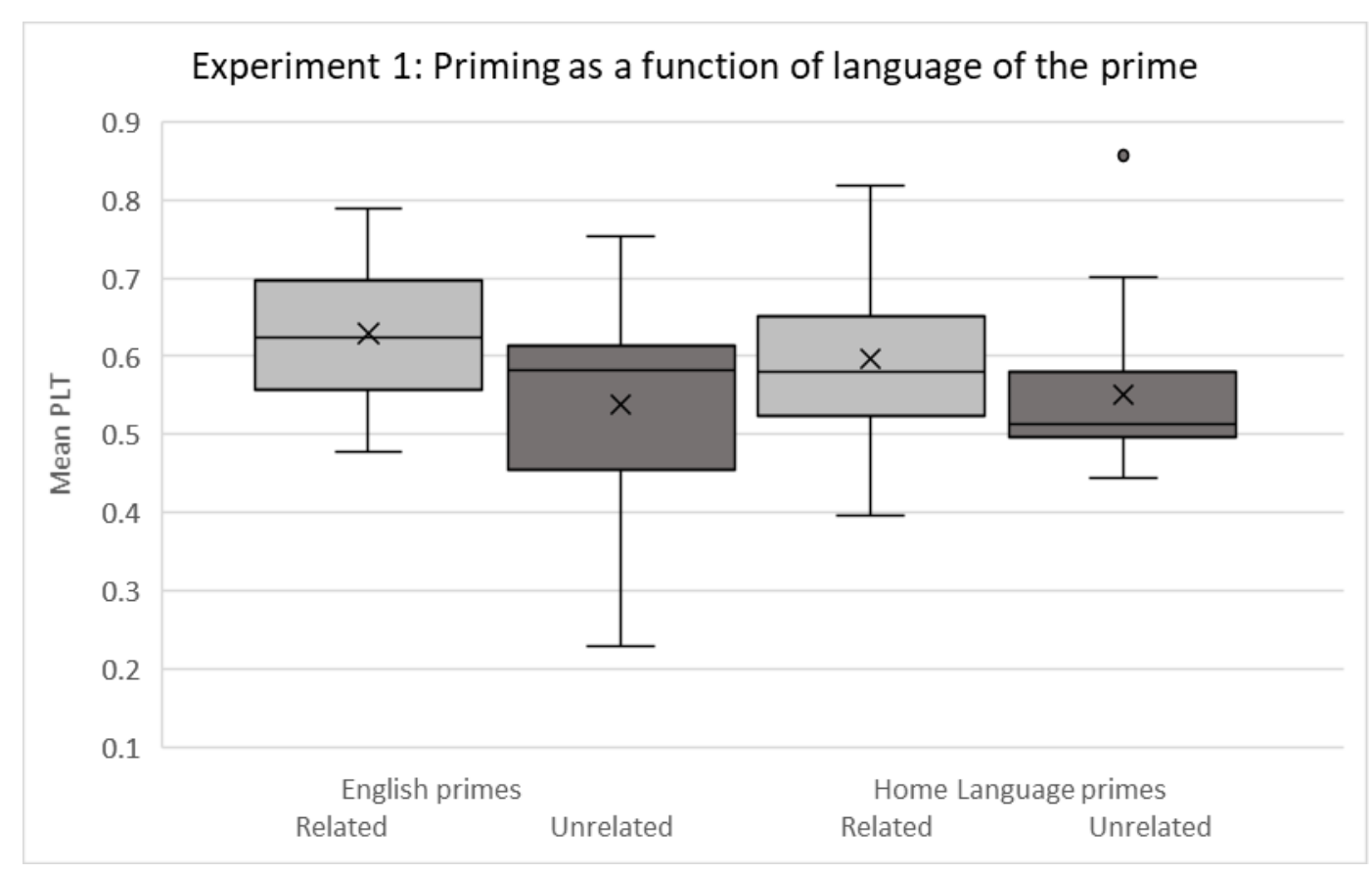

Figure 3 
Experiment 1: Priming effect as a function of language

dominance of the prime (defined through exposure)

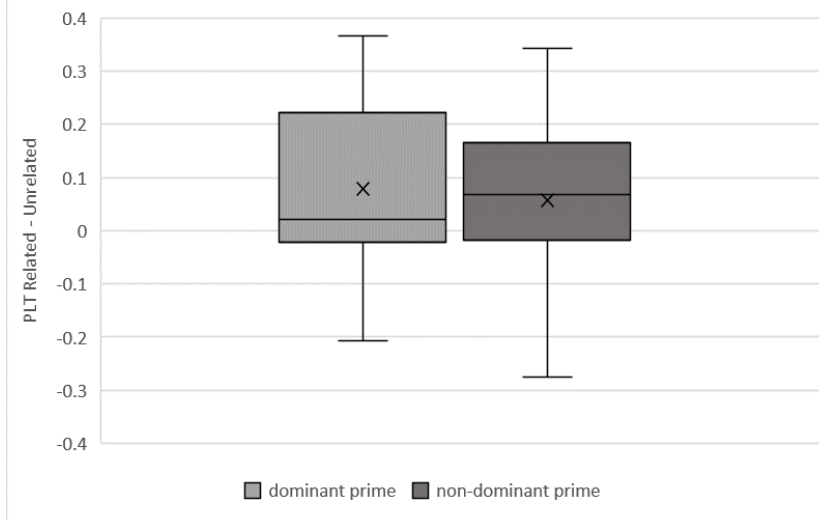

Experiment 1: Priming effect as a function of language dominance of the prime (defined through vocabulary)

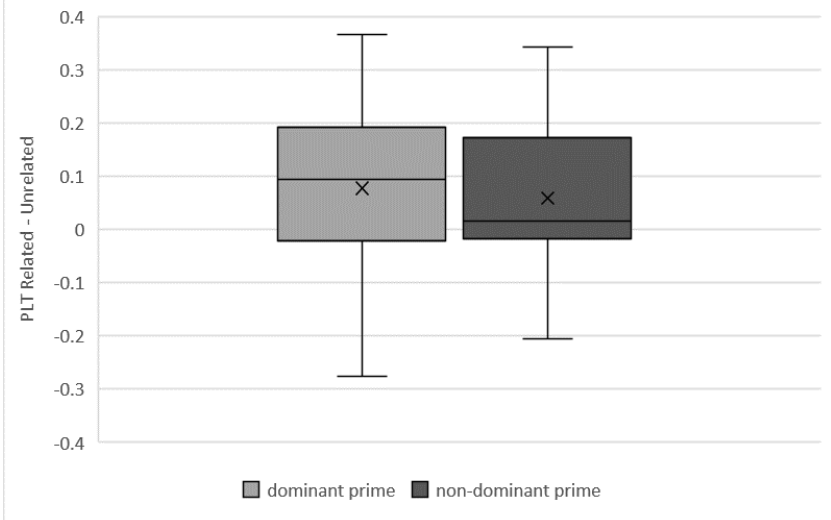

Figure 4 
Experiment 1: priming score as a function of language distance

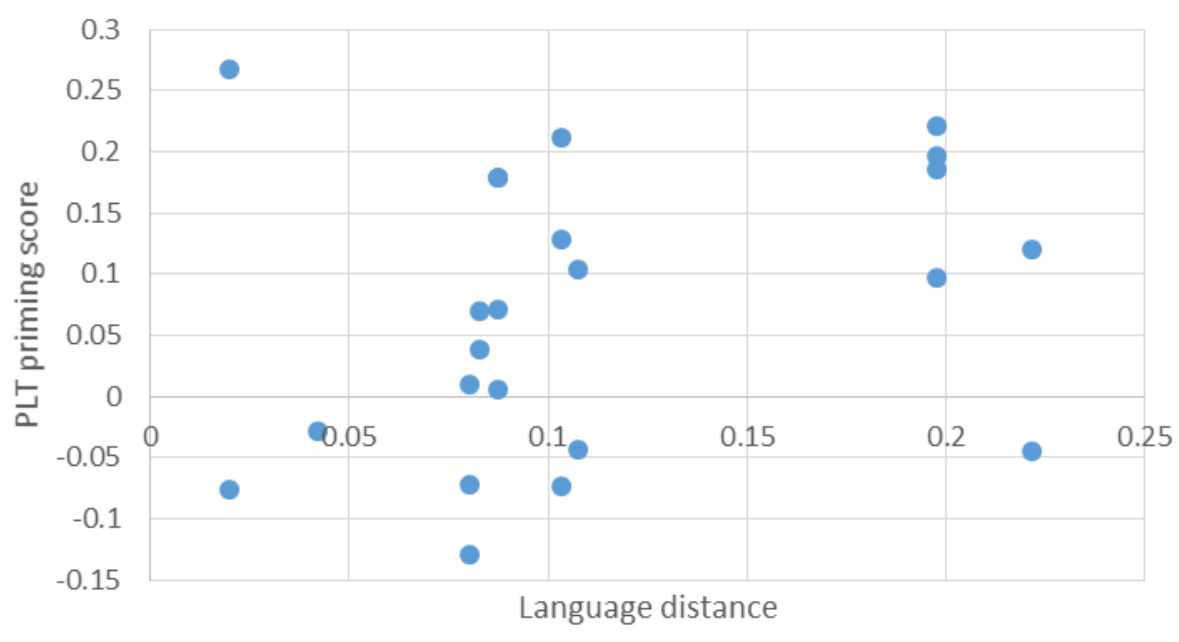

Figure 5 
Timecourse of PLT in Experiment 1: translation priming

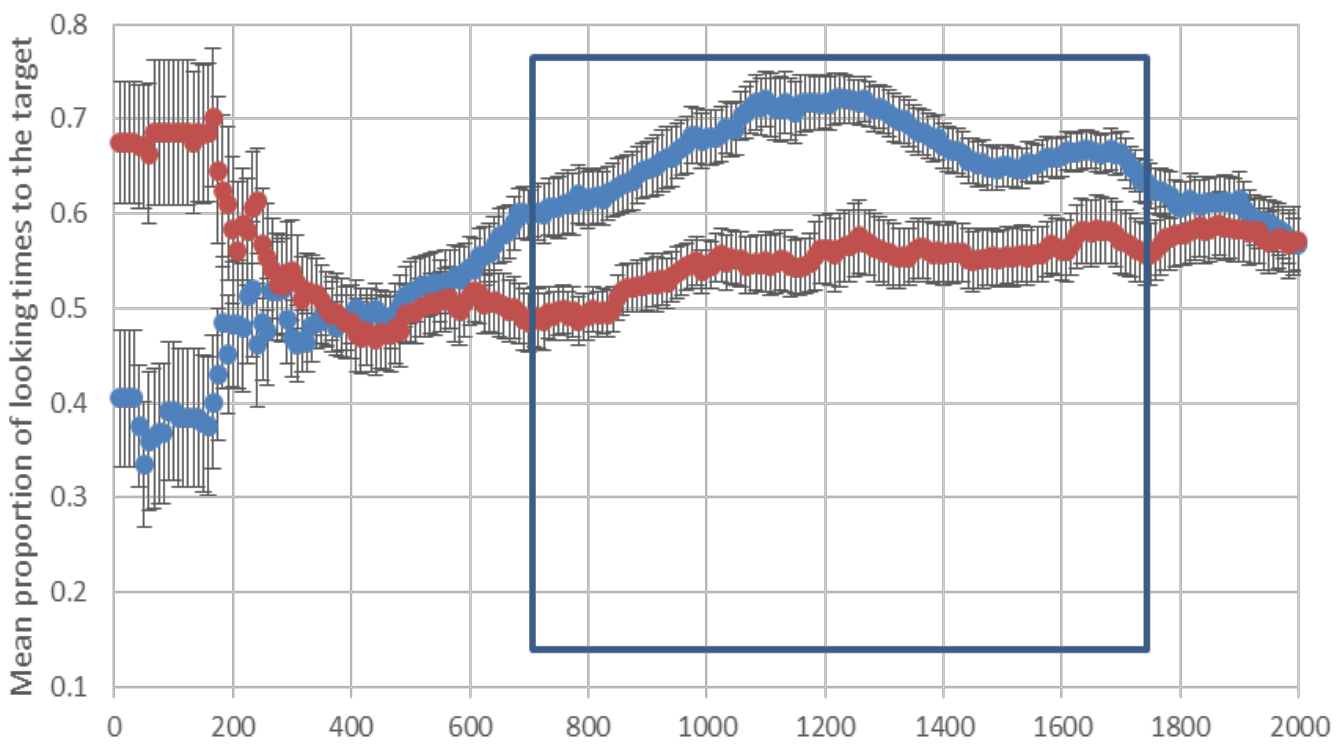

related

- unrelated

Time course of PLT in Experiment 2: semantic priming

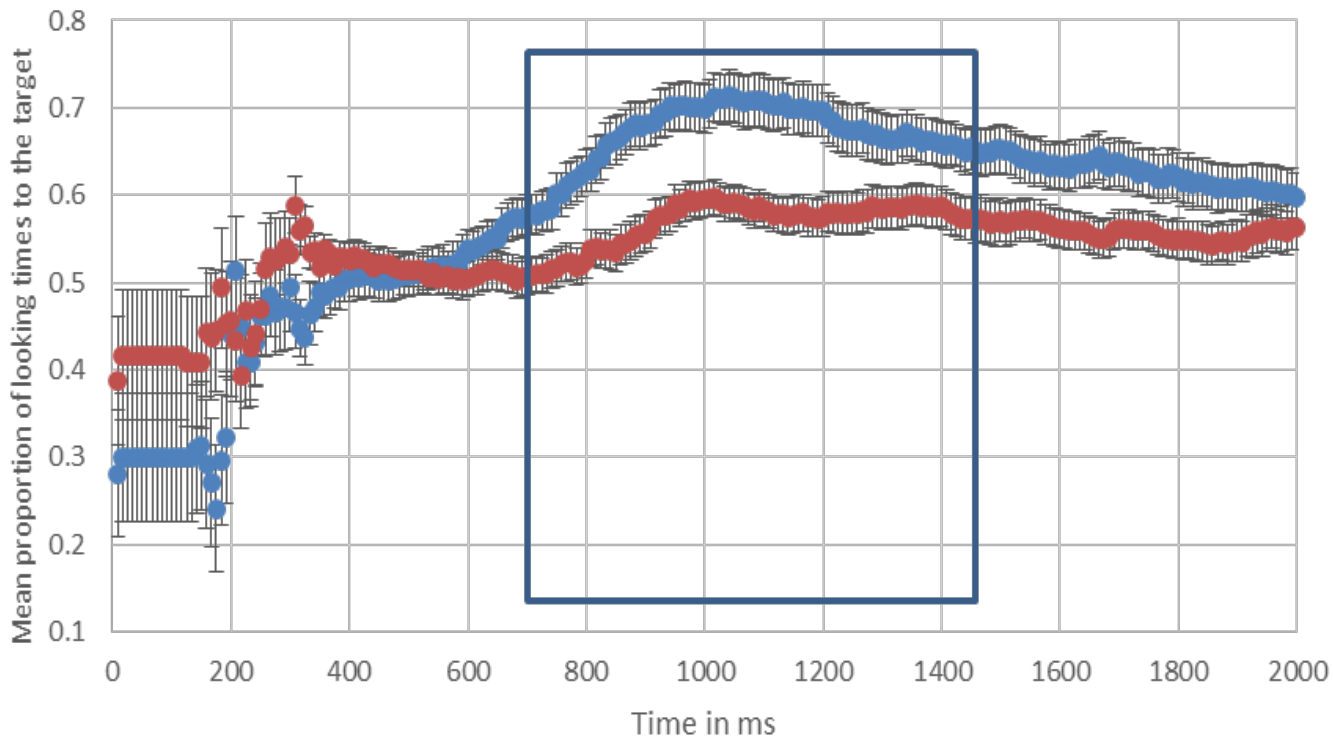

- related

- unrelated

Figure 6 


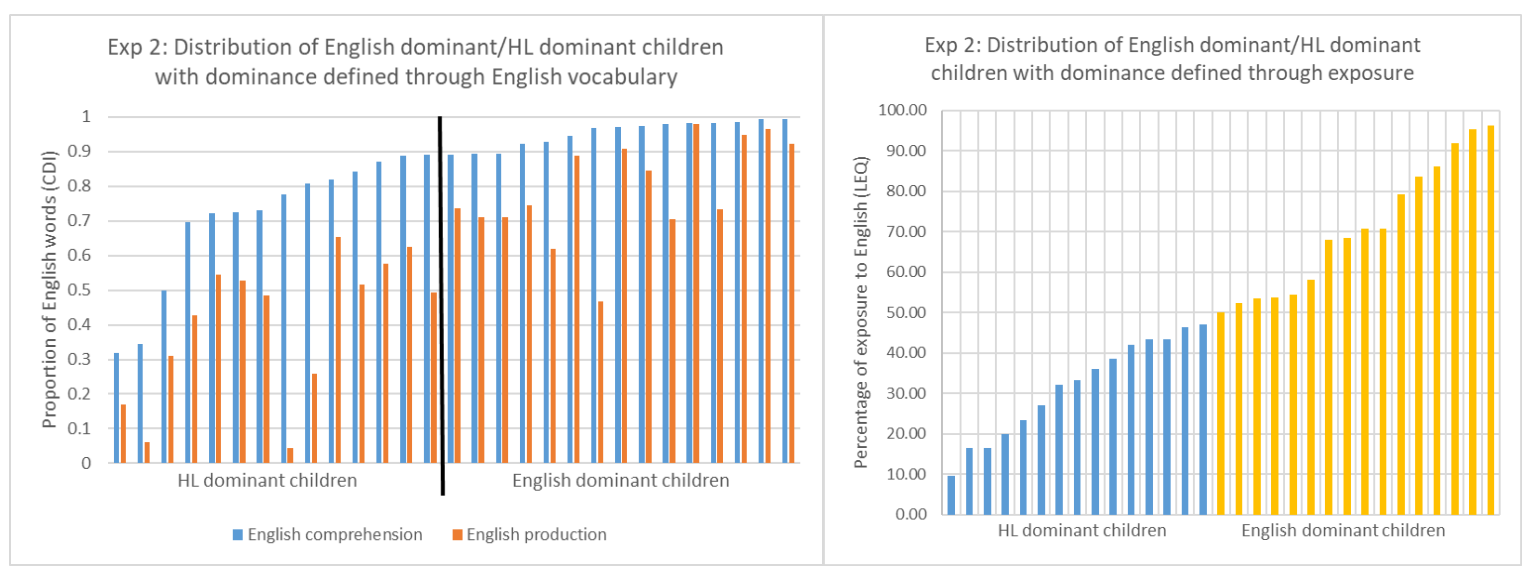

Figure 7 


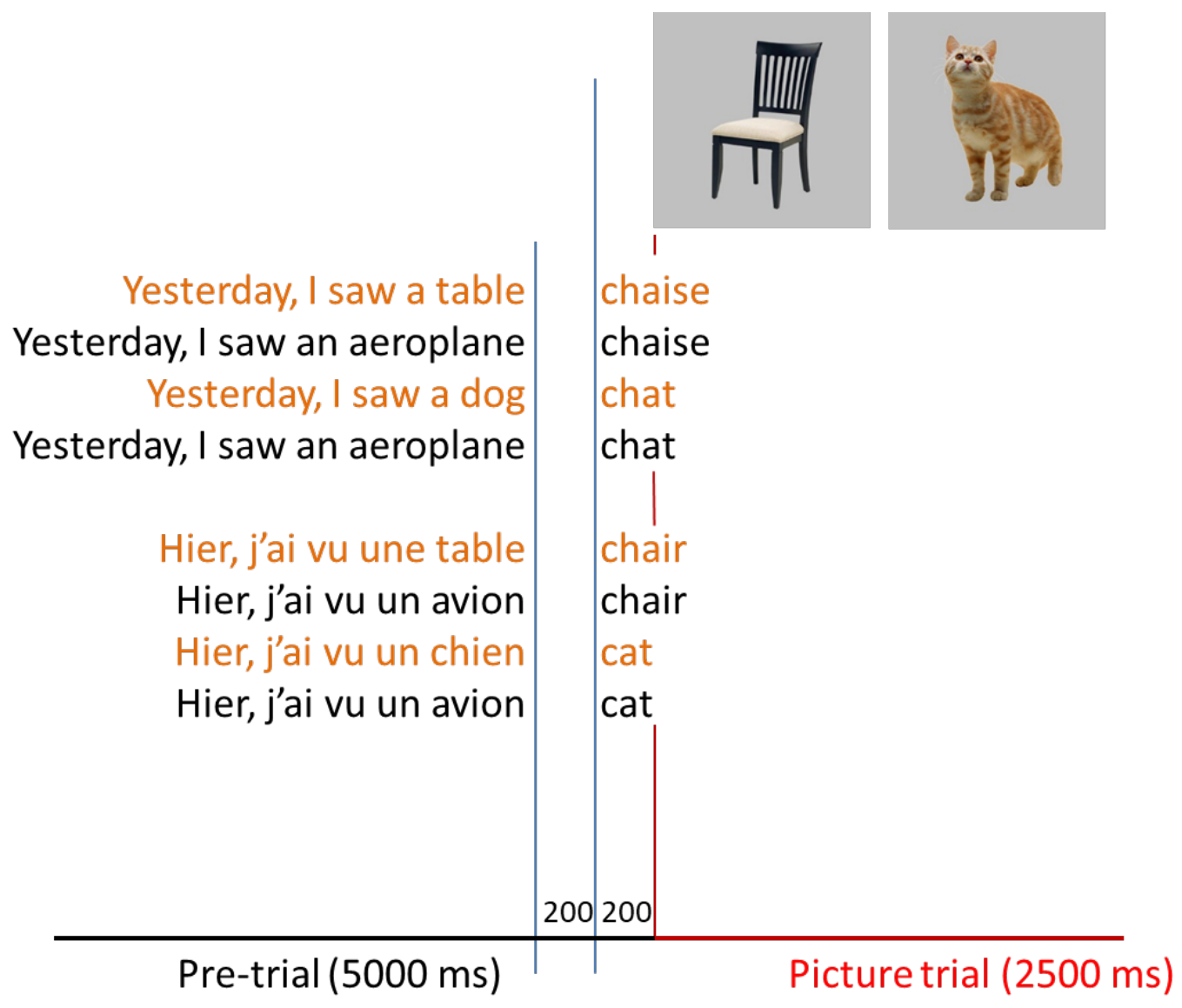

Figure 8 


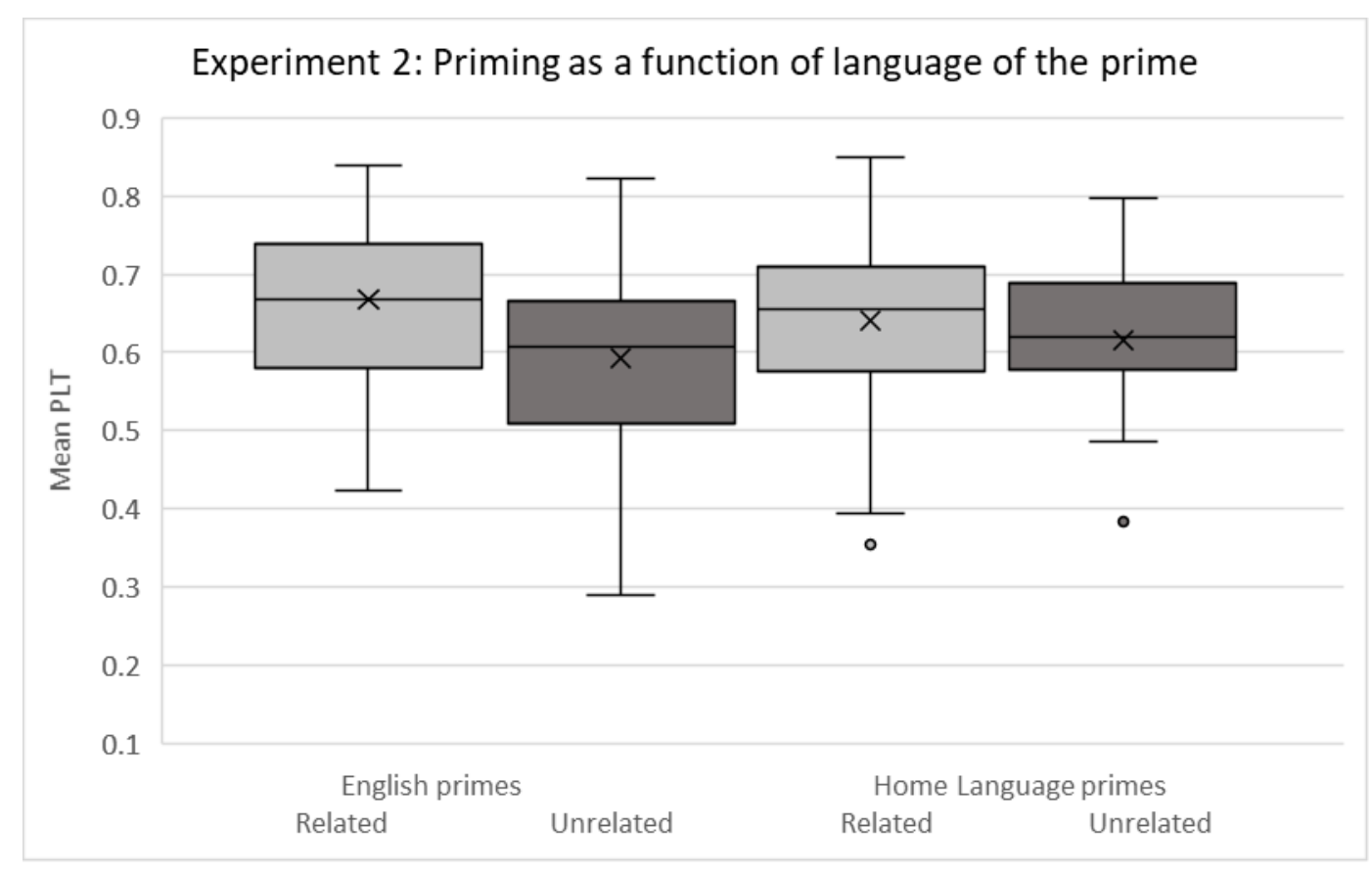

Figure 9 


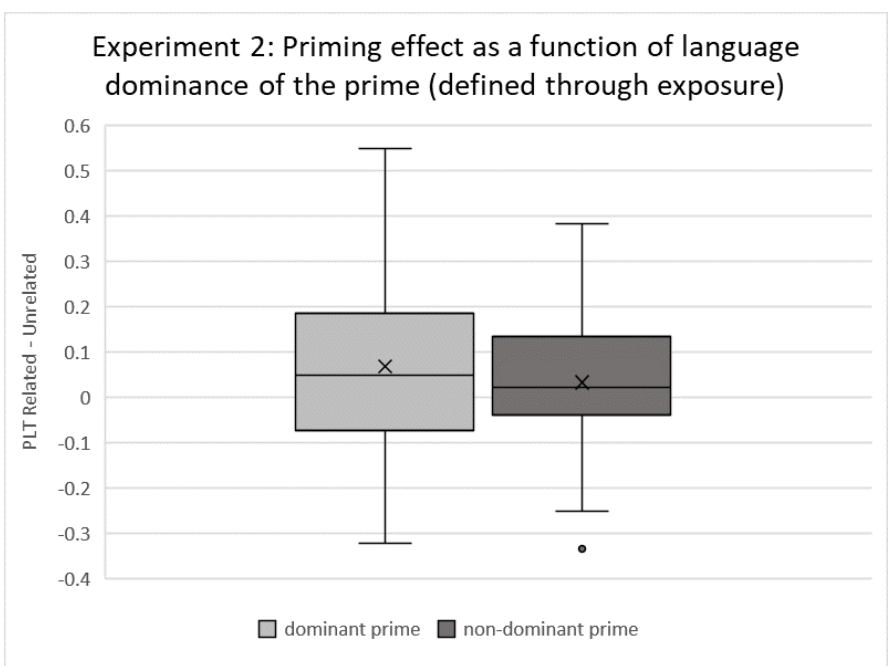

Experiment 2: Priming effect as a function of language dominance of the prime (defined through vocabulary)

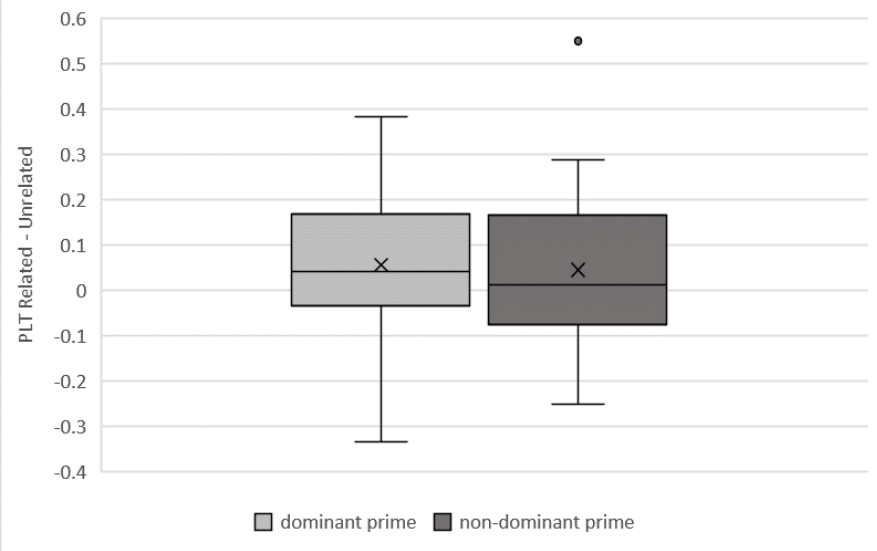

Figure 10 


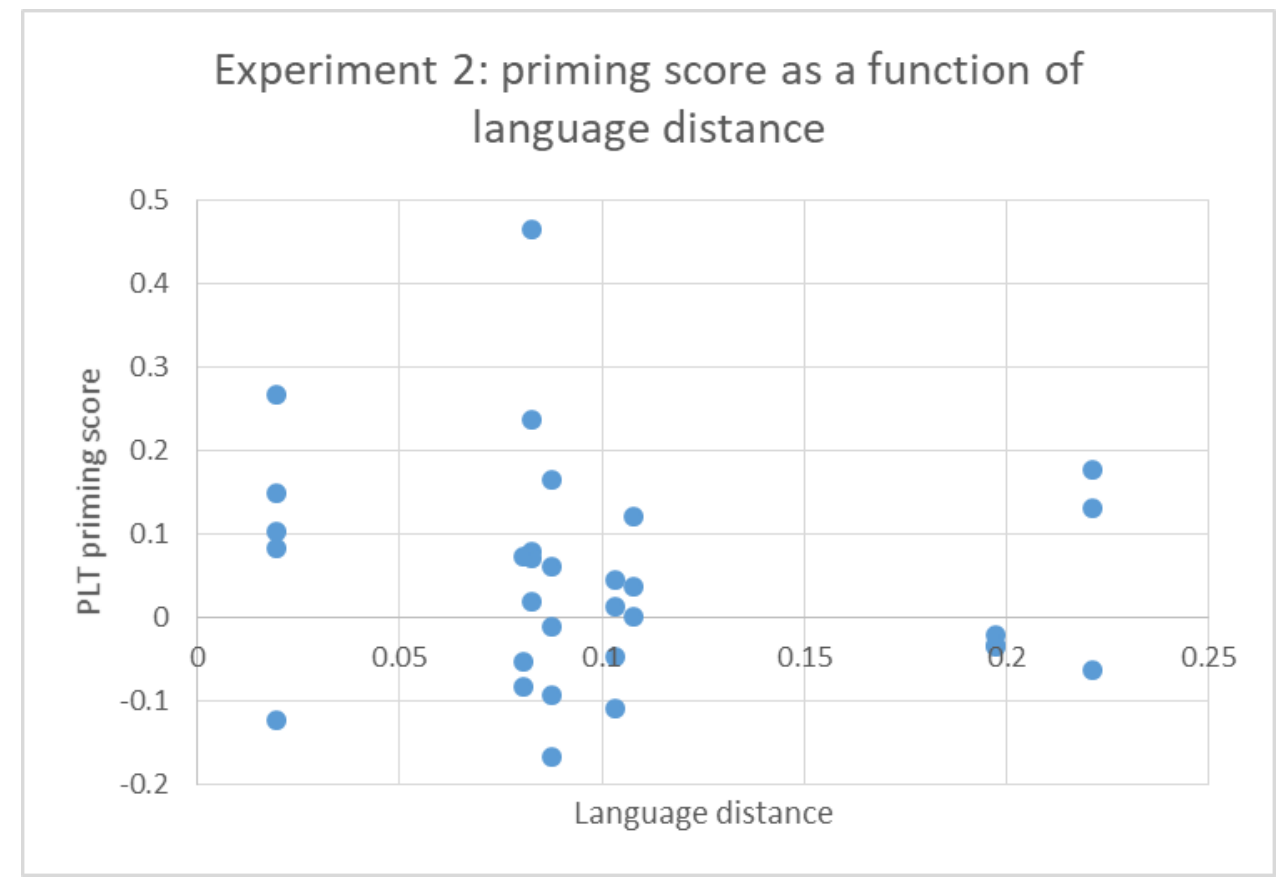

Figure 11 


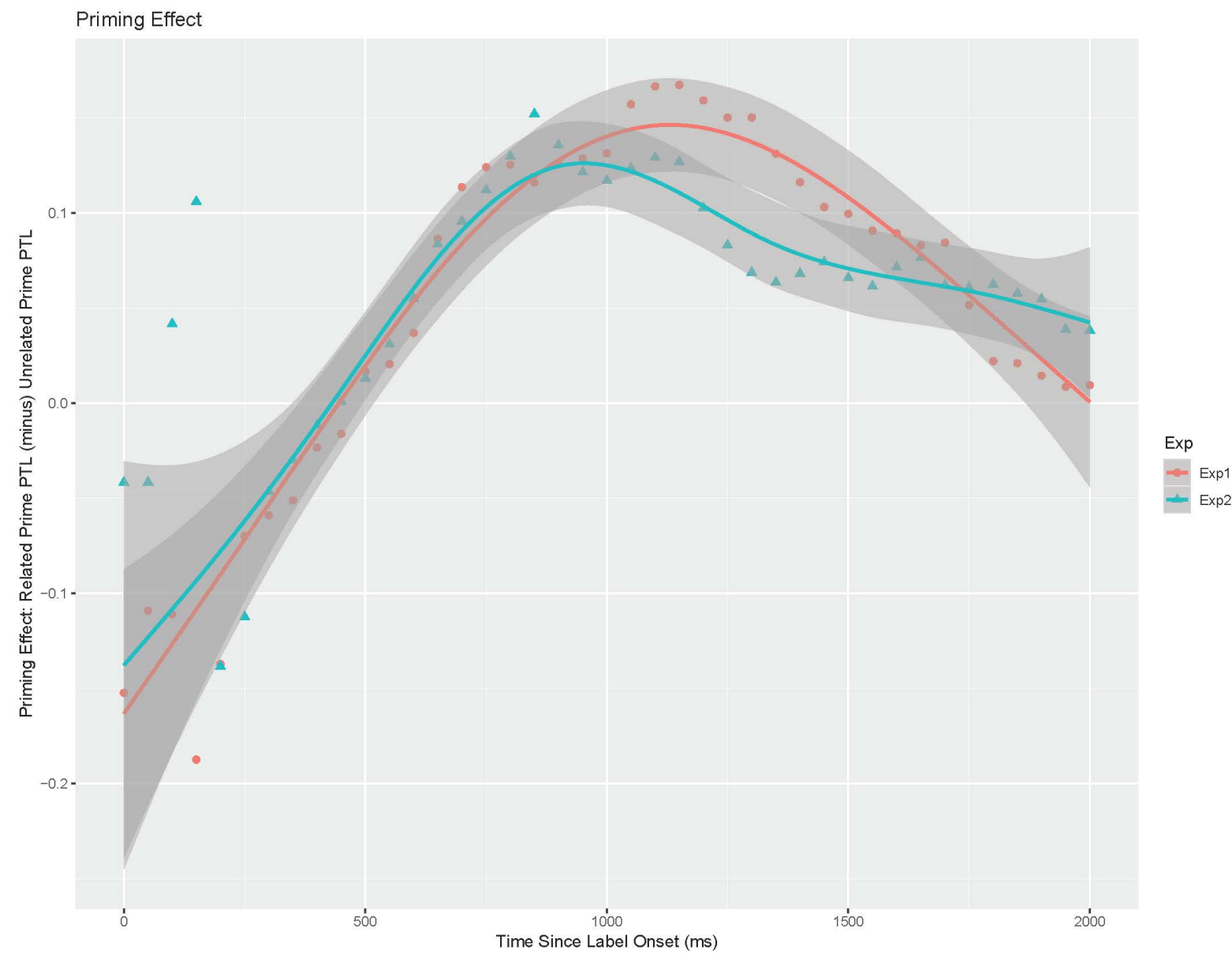

Figure 12

Appendix A: List of Communicative Developmental Inventories (CDIs)

Chinese Mandarin (Beijing) and Cantonese (Hong Kong):

Tardiff, T., \& Fletcher, P. (2008). Chinese Communicative Development Inventories: User's guide and manual. Beijing, China: Peking University Medical Press. 
Dutch:

Zink, I, \& Lejaegere, M. (2002). N-CDIs: Lijsten voor Communicatieve Ontwikkeling. Aanpassing en hernormering van de MacArthur CDIs van Fenson et al. Acco, Leuven (Belgium)/Leusden(Netherlands). (A CDI user's manual with normative and validity data).

French:

Kern, S., \& Gayraud, G. (2010). Inventaire Français du Développement Communicatif (IFDC), Grenoble, La Cigale, 978-2-912457-91-2.

German:

FRAKIS: Szagun, G., Stumper, B., \& Schramm, A. S. (2009). Fragebogen zur frühkindlichen Sprachentwicklung (FRAKIS) und FRAKIS-K (Kurzform). Frankfurt: Pearson Assessment. http://www.pearsonassessment.de

Greek:

Personal communication from Prof. Demetra Kati, University of Athens, May 2014.

Italian:

Caselli, M. C., \& Casadio, P. (1995). Il primo vocabolario del bambino: Guida all'uso del questionario MacArthur. Milan, Italy: Franco Angeli.

Polish:

Smoczyńska, M. (1999). Inwentarz Rozwoju Mowy i Komunikacji: Słowa i Zdania [Polish Adaptation of The MacArthur-Bates Communicative Development Inventory: Words and Sentences]. Unpublished material. Krakow: Jagiellonian University.

Portuguese:

Frota, S., Butler, J., Correia, S., Severino, C., Vicente, S., \& Vigário, M. (2016). Infant communicative development assessed with the European Portuguese MacArthur-Bates Communicative Development Inventories short forms. First Language, 36(5), 525-545.

Spanish:

López Ornat, S., Gallego, C., Gallo, P., Karousou, A., Mariscal, S., \& Martínez, M. Evaluación de los niveles de lenguaje y comunicación de los niños pequeños. Inventario de desarrollo comunicativo de MacArthur. ISBN: 84-7174-820-7.

Appendix B: List of stimuli in Experiment 1. 
For each home language (Italian, French, Polish, Spanish, German, Dutch, Portuguese,

Cantonese and Mandarin), translation equivalents and IPA transcription of the words in

each triplet (from 1 to 20). A triplet is made of two words acting as targets and distracters

(labelled target 1 and target 2) and an unrelated prime (Unr prime). The column Alt gives

the translation equivalent of any alternative word in that particular language. For example,

in Italian, for triplet 1 (bird, donkey and button), the prime button could not be used as it is a

cognate in Italian, therefore the alternative shoe was chosen (scarpe in Italian). There is no

Alt column in Mandarin as there were no cognates.

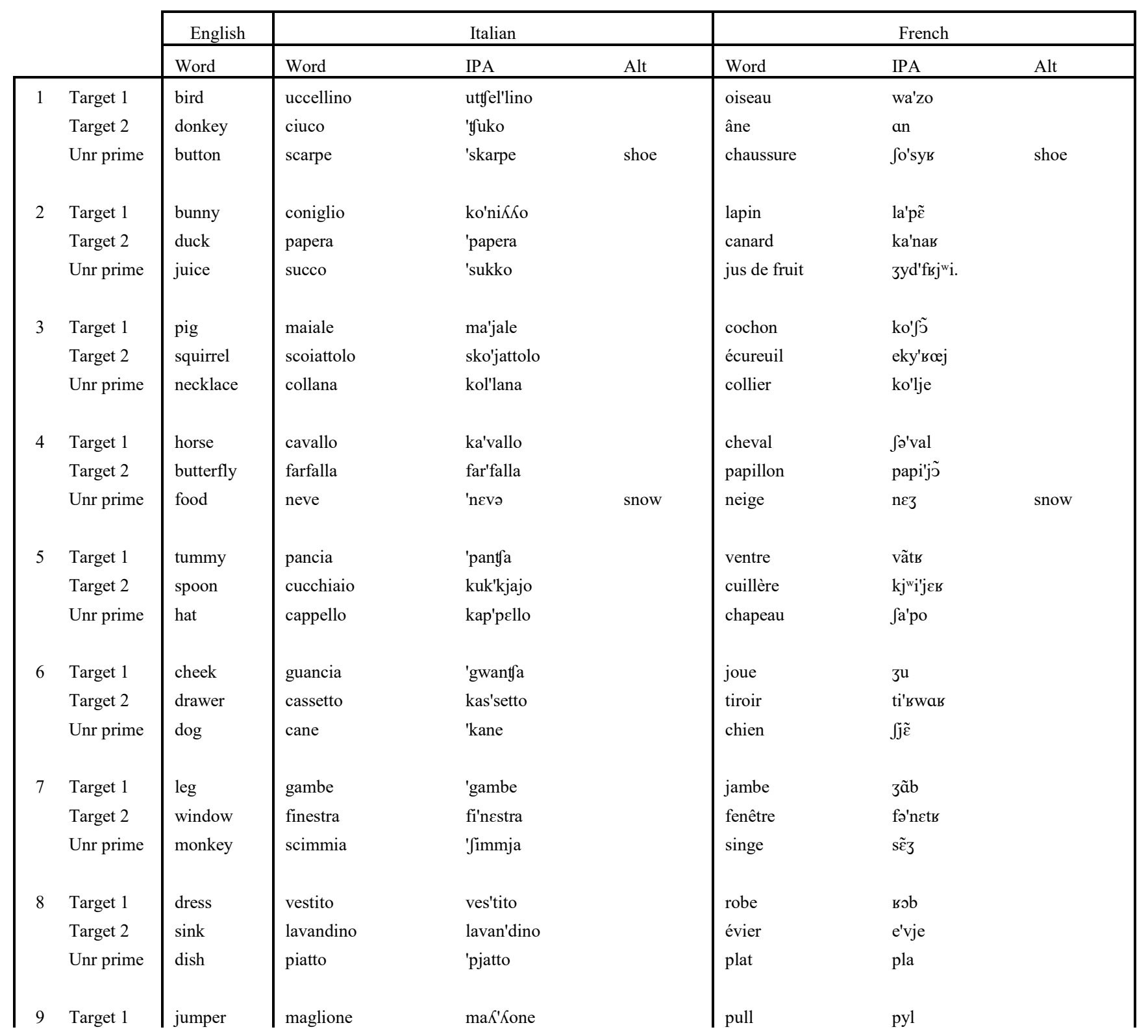




\begin{tabular}{|c|c|c|c|c|c|c|c|c|}
\hline & Target 2 & watch & orologio & oro'lodzo & & montre & mว̃ts & \\
\hline & Unr prime & peas & sedia & 'sedja & chair & porte & post & door \\
\hline \multirow[t]{3}{*}{10} & Target 1 & nappy & pannolino & panno'lino & & couche & $\mathrm{ku} \int$ & \\
\hline & Target 2 & cup & tazza & 'tattsa & & tasse & tas & \\
\hline & Unr prime & box & scatola & 'skatola & & poisson & pwa's̃̃ & fish \\
\hline \multirow[t]{3}{*}{11} & Target 1 & shirt & camicia & ka'mitfa & & verre & vєв & glass \\
\hline & Target 2 & tree & albero & 'albero & & arbre & авьь & \\
\hline & Unr prime & pillow & cuscino & $\mathrm{ku} \iint \mathrm{ino}$ & & oreiller & ове'је & \\
\hline \multirow[t]{3}{*}{12} & Target 1 & trousers & pantaloni & panta'loni & & pantalon & pãta'lõ & \\
\hline & Target 2 & blanket & coperta & ko'perta & & couverture & kuves'tув & \\
\hline & Unr prime & bike & bicchiere & bik'kjcre & glass & vélo & ve'lo & \\
\hline \multirow[t]{3}{*}{13} & Target 1 & chips & patatine & pata'tine & & frites & fuit & \\
\hline & Target 2 & bin & cestino & fes'tino & & poubelle & pu'bel & \\
\hline & Unr prime & lorry & camion & 'kamjon & & camion & ka'mj̃̃ & \\
\hline \multirow[t]{3}{*}{14} & Target 1 & cheese & formaggio & for'maddzo & & fromage & fro'maz & \\
\hline & Target 2 & doll & bambola & 'bambola & & poupée & pu'pe & \\
\hline & Unr prime & soap & calze & 'kaltse & sock & chaussette & fo'sst & sock \\
\hline \multirow[t]{3}{*}{15} & Target 1 & cow & mucca & 'mukka & & vache & $\mathrm{va} \int$ & \\
\hline & Target 2 & bee & ape & 'ape & & abeille & $a^{\prime} b \varepsilon j$ & \\
\hline & Unr prime & highchair & seggiolone & seddzo'lone & & chaise haute & $\int \varepsilon^{\prime} z o t$ & \\
\hline \multirow[t]{3}{*}{16} & Target 1 & hoover & aspirapolvere & aspira'polvere & & aspirateur & аsріка'tœь & \\
\hline & Target 2 & picture & foto & 'foto & & photo & fo'to & \\
\hline & Unr prime & slide & scivolo & 'fivolo & & toboggan & tobo'gã & \\
\hline \multirow[t]{3}{*}{17} & Target 1 & car & automobile & awto'msbile & & voiture & vwa'tys & \\
\hline & Target 2 & glasses & occhiali & ok'kjali & & lunettes & ly'net & \\
\hline & Unr prime & chicken & pulcino & pul'tyino & & poule & pul & \\
\hline \multirow[t]{3}{*}{18} & Target 1 & plane & aereo & a'Ereo & & avion & a'vjõ & \\
\hline & Target 2 & bucket & secchiello & sek'kjello & & seau & so & \\
\hline & Unr prime & food & cibo & 'tyibo & & nourriture & пивi'tув & \\
\hline \multirow[t]{3}{*}{19} & Target 1 & coat & pesciolino & pe $\iint o^{\prime}$ lino & fish & manteau & mã'to & \\
\hline & Target 2 & stairs & orso & orso & bear & escalier & eska'lje & \\
\hline & Unr prime & plate & scodella & sko'della & bowl & assiette & a'sjet & \\
\hline \multirow[t]{3}{*}{20} & Target 1 & money & soldi & 'soldi & & argent & ав'zã & \\
\hline & Target 2 & towel & asciugamano & affuga'mano & & serviette & ses'vjet & \\
\hline & Unr prime & jacket & porta & 'porta & door & veste & vest & \\
\hline
\end{tabular}




\begin{tabular}{|c|c|c|c|c|c|c|c|c|}
\hline & & \multirow{2}{*}{$\begin{array}{l}\text { English } \\
\text { Word } \\
\end{array}$} & \multicolumn{3}{|c|}{ Polish } & \multicolumn{3}{|c|}{ Spanish } \\
\hline & & & Word & IPA & Alt & Word & IPA & Alt \\
\hline \multirow[t]{3}{*}{1} & Target 1 & bird & ptaszek & 'ptafek & & pájaro & 'paxaro & \\
\hline & Target 2 & donkey & osioł & '?o60w & & burro & 'buro & \\
\hline & Unr prime & button & Guzik & 'guzik & & zapato & $\theta$ a'pato & shoe \\
\hline \multirow[t]{3}{*}{2} & Target 1 & bunny & zajączek & za'jõntfદk & & conejo & ko'nexo & \\
\hline & Target 2 & duck & ryba & 'riba & fish & pato & 'pato & \\
\hline & Unr prime & juice & sok & sok & & zumo & ' $\theta$ umo & \\
\hline \multirow[t]{3}{*}{3} & Target 1 & pig & świnka & 'cfinka & & cerdo & 'Өегðо & \\
\hline & Target 2 & squirrel & wiewiórka & 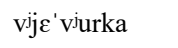 & & ardilla & ar'ðiКa & \\
\hline & Unr prime & necklace & naszyjnik & na'Jijjnik & & collar & ko'Kar & \\
\hline \multirow[t]{3}{*}{4} & Target 1 & horse & koń & kən & & caballo & ka'ßaאo & \\
\hline & Target 2 & butterfly & motyl & 'motil & & mariposa & mari'posa & \\
\hline & Unr prime & food & jedzenie & je'cken & & comida & ko'miða & \\
\hline \multirow[t]{3}{*}{5} & Target 1 & tummy & brzuch & bzux & & barriga & ba'riүa & \\
\hline & Target 2 & spoon & łyżka & 'wifka & & cuchara & ku'ffara & \\
\hline & Unr prime & hat & kapelusz & ka'peluf & & camión & ka'mjon & lorry \\
\hline \multirow[t]{3}{*}{6} & Target 1 & cheek & policzek & po'litfek & & mejilla & me'xiאa & \\
\hline & Target 2 & drawer & szuflada & fu'flada & & cajón & ka'xon & \\
\hline & Unr prime & $\operatorname{dog}$ & pies & $\mathrm{p}_{\mathrm{j} j \varepsilon \mathrm{s}}$ & & perro & 'pero & \\
\hline \multirow[t]{3}{*}{7} & Target 1 & leg & noga & 'noga & & pierna & 'pjerna & \\
\hline & Target 2 & window & okno & 'Pokno & & ventana & ben'tana & \\
\hline & Unr prime & monkey & pająk & 'pajøyk & spider & pez & pe $\theta$ & fish \\
\hline \multirow[t]{3}{*}{8} & Target 1 & dress & sukienka & su'cenka & & vestido & bes'tiðo & \\
\hline & Target 2 & sink & zlew & $\mathrm{zl} \varepsilon f$ & & lavabo & la' $\beta \mathrm{a} \beta o$ & \\
\hline & Unr prime & dish & naczynie & na'tfing & & plato & 'plato & \\
\hline \multirow[t]{3}{*}{9} & Target 1 & jumper & sweter & 'sfeter & & jersey & 'xersei & \\
\hline & Target 2 & watch & zegarek & z $\varepsilon^{\prime}$ garck & & reloj & 'relox & \\
\hline & Unr prime & peas & groszek & 'grofek & & guisantes & gi'santes & \\
\hline \multirow[t]{3}{*}{10} & Target 1 & nappy & pieluszka & pjje'lufka & & pañal & 'panal & \\
\hline & Target 2 & cup & kubek & 'kubck & & tarro & 'taro & \\
\hline & Unr prime & box & pudełko & pu'dewko & & caja & 'kaxa & \\
\hline \multirow[t]{3}{*}{11} & Target 1 & shirt & koszula & ko'fula & & camisa & ka'misa & \\
\hline & Target 2 & tree & drzewo & 'dzevo & & árbol & 'arßol & \\
\hline & Unr prime & pillow & poduszka & po'dufka & & almohada & almo'aða & \\
\hline \multirow[t]{3}{*}{12} & Target 1 & trousers & spodnie & 'spodne & & pantalón & panta'lon & \\
\hline & Target 2 & blanket & kołdra & 'kowdra & & manta & 'manta & \\
\hline & Unr prime & bike & rower & 'rover & & columpio & ko'lumpjo & swing \\
\hline \multirow[t]{3}{*}{13} & Target 1 & chips & chrupki & 'xrupci & & patatasfritas & patatas'fritas & \\
\hline & Target 2 & bin & kosz na śmieci & 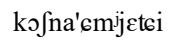 & & basura & ba'sura & \\
\hline & Unr prime & lorry & ciężarówka & tc $\tilde{\varepsilon}^{w}$ za'rufk.a & & llave & 'Kaße & key \\
\hline
\end{tabular}




\begin{tabular}{|c|c|c|c|c|c|c|c|c|}
\hline \multirow[t]{3}{*}{14} & Target 1 & cheese & ser & scr & & queso & 'keso & \\
\hline & Target 2 & doll & lalka & 'lalka & & muñeca & mu'neka & \\
\hline & Unr prime & soap & basen & 'basen & pool & jabón & xa'ßon & \\
\hline \multirow[t]{3}{*}{15} & Target 1 & cow & kwiatek & 'kvjatck & flower & vaca & 'baka & \\
\hline & Target 2 & bee & nożyczki & no'zitfci & scissors & abeja & $a^{\prime} \beta e x a$ & \\
\hline & Unr prime & highchair & wysokie krzesełko & visəcek $\int \varepsilon$ 's $\varepsilon w k \jmath$ & & trona & 'trona & \\
\hline \multirow[t]{3}{*}{16} & Target 1 & hoover & odkurzacz & Pot'kuzatf & & aspiradora & aspira'ðora & \\
\hline & Target 2 & picture & zdjęcie & 'zdjentec & & foto & 'foto & \\
\hline & Unr prime & slide & ślizgawka & clij'zgafka & & ratón & ra'ton & mouse \\
\hline \multirow[t]{3}{*}{17} & Target 1 & car & samochód & sa'moxut & & zanahoria & Өana'orja & carrot \\
\hline & Target 2 & glasses & okulary & Poku'lari & & tobogán & toßo'yan & slide \\
\hline & Unr prime & chicken & żółw & zuwf & turtle & pollito & po'Kito & \\
\hline \multirow[t]{3}{*}{18} & Target 1 & plane & samolot & sa'molot & & avión & $\mathrm{a}^{\prime} \beta \mathrm{jon}$ & \\
\hline & Target 2 & bucket & wiaderko & vjja'derko & & cubo & 'kußo & \\
\hline & Unr prime & food & ciastko & 'tcastko & biscuit & galleta & ga'Keta & biscuit \\
\hline \multirow[t]{3}{*}{19} & Target 1 & coat & płaszcz & pwaft & & abrigo & $\mathrm{a}^{\prime} \beta$ ri $\gamma_{0}$ & \\
\hline & Target 2 & stairs & schody & 'sxodi & & escalera & eska'lera & \\
\hline & Unr prime & plate & miseczka & mi'setfka & bowl & vaso & 'baso & glass \\
\hline \multirow[t]{3}{*}{20} & Target 1 & money & pieniądze & 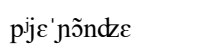 & & naranja & na'ranxa & orange \\
\hline & Target 2 & towel & ręcznik & 'rẽntfnik & & silla & 'siKa & chair \\
\hline & Unr prime & jacket & kurtka & 'kurtka & & puerta & 'pwerta & door \\
\hline
\end{tabular}

\begin{tabular}{|c|c|c|c|c|c|c|c|c|}
\hline & & \multirow{2}{*}{$\begin{array}{l}\text { English } \\
\text { Word }\end{array}$} & \multicolumn{3}{|c|}{ German } & \multicolumn{3}{|c|}{ Dutch } \\
\hline & & & Word & IPA & Alt & Word & IPA & Alt \\
\hline \multirow[t]{3}{*}{1} & Target 1 & bird & Vogel & 'fo:gəl & & vogel & 'voyəl & \\
\hline & Target 2 & donkey & Esel & 'e:zəl & & ezel & 'e:zəl & \\
\hline & Unr prime & button & Knopf & knopf & & knoop & kno:p & \\
\hline \multirow[t]{3}{*}{2} & Target 1 & bunny & Kaninchen & ka'ni:nçən & & konijn & ko'ncin & \\
\hline & Target 2 & duck & Ente & 'Entə & & eend & e:nt & \\
\hline & Unr prime & juice & Saft & zaft & & sap & sap & \\
\hline \multirow[t]{3}{*}{3} & Target 1 & pig & Schwein & fvain & & varken & 'varkə & \\
\hline & Target 2 & squirrel & Eichhörnchen & aiç'hørnçən & & eekhoorn & 'e:khorn & \\
\hline & Unr prime & necklace & Halskette & 'halsketə & & ketting & 'ketın & \\
\hline \multirow[t]{3}{*}{4} & Target 1 & horse & Pferd & pfe:rt & & paard & pa:rt & \\
\hline & Target 2 & butterfly & Schmetterling & 'Smetərlın & & vlinder & 'vlindər & \\
\hline & Unr prime & food & Essen & 'Esən & & sinaasappel & 'sinəzapəl & orange \\
\hline
\end{tabular}




\begin{tabular}{|c|c|c|c|c|c|c|c|c|}
\hline \multirow[t]{3}{*}{5} & Target 1 & tummy & Bauch & baux & & buik & bœyk & \\
\hline & Target 2 & spoon & Löffel & 'lœfəl & & lepel & 'lepəl & \\
\hline & Unr prime & hat & Mütze & 'mytsə & & kikker & 'kıkər & frog \\
\hline \multirow[t]{3}{*}{6} & Target 1 & cheek & Wange & 'vayə & & wang & way & \\
\hline & Target 2 & drawer & Schublade & 'fu:pla:də & & laatje & 'la:tfə & \\
\hline & Unr prime & $\operatorname{dog}$ & Hund & hont & & hond & hont & \\
\hline \multirow[t]{3}{*}{7} & Target 1 & leg & Bein & bain & & been & be:n & \\
\hline & Target 2 & window & Fenster & 'fenstər & & raam & $\mathrm{ra}: \mathrm{m}$ & \\
\hline & Unr prime & monkey & Affe & 'afə & & aap & $a: p$ & \\
\hline \multirow[t]{3}{*}{8} & Target 1 & dress & Kleid & klait & & jurkje & 'jœ:kjə & \\
\hline & Target 2 & sink & Spüle & 'Spy:1.ə & & gootsteen & 'yotste:n & \\
\hline & Unr prime & dish & Schüssel & 'SYsəl & & schotel & 'sxotəl & \\
\hline \multirow[t]{3}{*}{9} & Target 1 & jumper & Pullover & pu'lo:vər & & trui & trœy & \\
\hline & Target 2 & watch & Uhr & u:r & & horloge & hər'lo:xə & \\
\hline & Unr prime & peas & Tür & tyr & door & erwtjes & 'crtjəs & \\
\hline \multirow[t]{3}{*}{10} & Target 1 & nappy & Windel & 'vindəl & & luier & 'lœyjər & \\
\hline & Target 2 & cup & Becher & 'beçər & & beker & 'be:kər & \\
\hline & Unr prime & box & Schaukel & 'Jaukəl & swing & doos & do:s & \\
\hline \multirow[t]{3}{*}{11} & Target 1 & shirt & Hemd & hemt & & broek & bruk & trousers \\
\hline & Target 2 & tree & Baum & baum & & boom & bo:m & \\
\hline & Unr prime & pillow & Kissen & 'kisən & & hoofdkussen & 'ho:ftkysə & \\
\hline \multirow[t]{3}{*}{12} & Target 1 & trousers & Hose & 'ho:zə & & hemd & hemt & shirt \\
\hline & Target 2 & blanket & Decke & 'dekə & & deken & 'dekə & \\
\hline & Unr prime & bike & Fahrrad & 'fa:rra:t & & fiets & fits & \\
\hline \multirow[t]{3}{*}{13} & Target 1 & chips & Pommes & 'poməs & & frietjes & 'fritjəs & \\
\hline & Target 2 & bin & Mülleimer & 'mylaimər & & vuilnisbak & 'vœylnızba:k & \\
\hline & Unr prime & lorry & Schlüssel & 'flysəl & key & vrachtwagen & 'vraxtwa:xə & \\
\hline \multirow[t]{3}{*}{14} & Target 1 & cheese & Käse & 'ke:zə & & kaas & $\mathrm{ka}: \mathrm{s}$ & \\
\hline & Target 2 & doll & Puppe & 'pupə & & pop & pop & \\
\hline & Unr prime & soap & Seife & 'zaifə & & zeep & zep & \\
\hline \multirow[t]{3}{*}{15} & Target 1 & cow & Blume & 'blu:mə & flower & bloem & blum & flower \\
\hline & Target 2 & bee & Schere & ' $\varepsilon \varepsilon r ə$ & scissors & schaar & sxa:r & scissors \\
\hline & Unr prime & highchair & Hochstuhl & 'ho:xftu:1 & & kinderstoel & 'kindərstul & \\
\hline \multirow[t]{3}{*}{16} & Target 1 & hoover & Staubsauger & ' Jtaupzaugər & & stofzuiger & 'stofsœyxər & \\
\hline & Target 2 & picture & Bild & bilt & & foto & 'foto & \\
\hline & Unr prime & slide & Rutsche & 'rotfa & & glijbaan & 'xleiba:n & \\
\hline \multirow[t]{3}{*}{17} & Target 1 & car & Auto & 'auto: & & auto & 'auto & \\
\hline & Target 2 & glasses & Brille & 'brilə & & bril & bril & \\
\hline & Unr prime & chicken & Huhn & hu:n & & schildpad & 'sxiltpat & turtle \\
\hline \multirow[t]{2}{*}{18} & Target 1 & plane & Flugzeug & 'flu:ktsərk & & vliegtuig & 'vlixtœyx & \\
\hline & Target 2 & bucket & Eimer & 'aimər & & emmer & 'cmər & \\
\hline
\end{tabular}




\begin{tabular}{|c|c|c|c|c|c|c|c|c|}
\hline & Unr prime & food & Keks & ke:ks & biscuit & eten & 'e:tə & \\
\hline \multirow[t]{3}{*}{19} & Target 1 & coat & Mantel & 'mantəl & & jas & jas & \\
\hline & Target 2 & stairs & Treppe & 'trepə & & trap & trap & \\
\hline & Unr prime & plate & Teller & 'telər & & bord & bort & \\
\hline \multirow[t]{3}{*}{20} & Target 1 & money & Geld & gelt & & geld & xelt & \\
\hline & Target 2 & towel & Handtuch & 'hanttu:x & & handdoek & 'handuk & \\
\hline & Unr prime & jacket & Schlafzimmer & 'fla:ftsimər & bedroom & slaapkamer & 'sla:pka:mər & bedroom \\
\hline
\end{tabular}

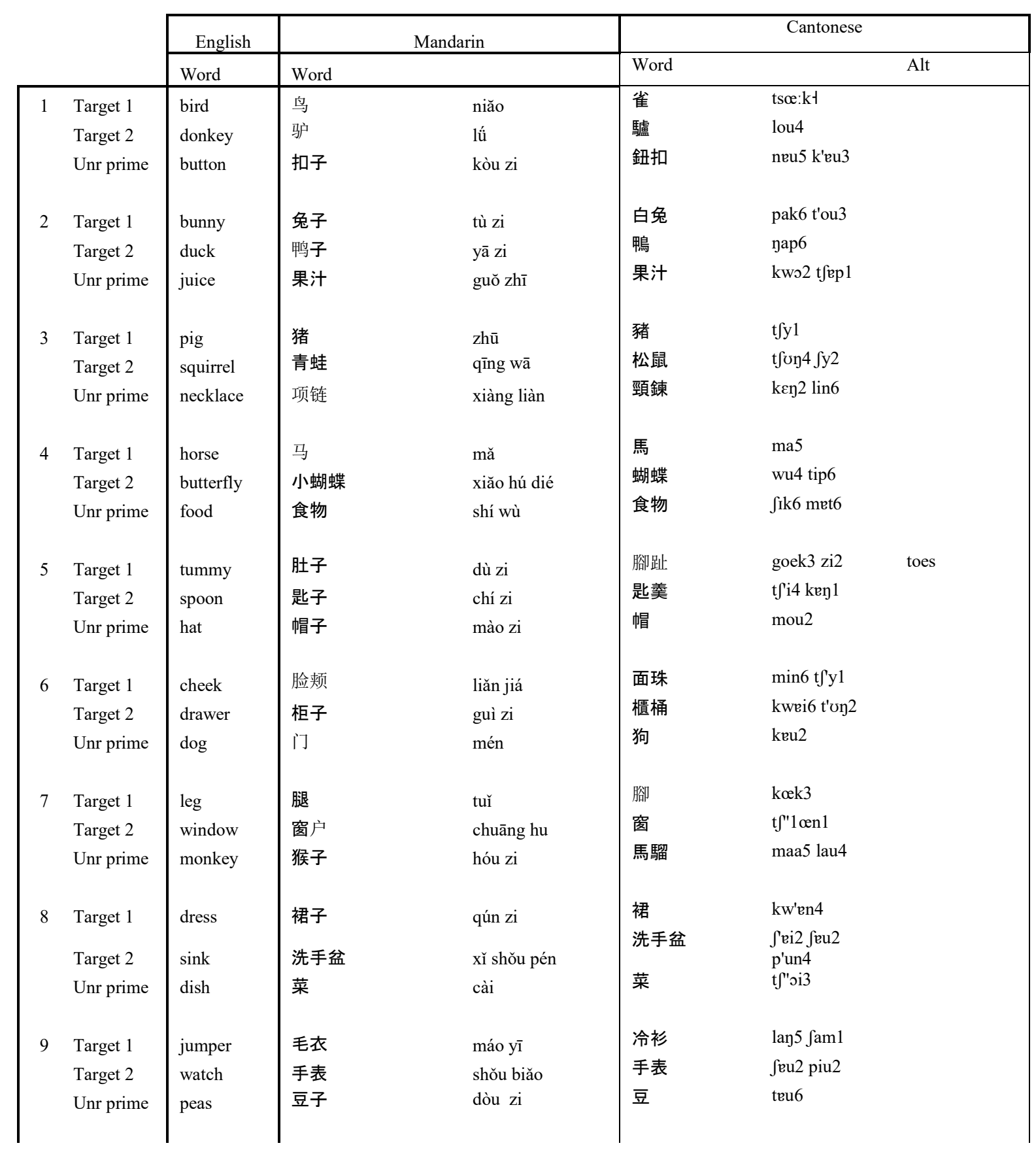




\begin{tabular}{|c|c|c|c|c|c|c|c|}
\hline \multirow[t]{3}{*}{10} & Target 1 & nappy & 纸尿布 & zhǐ niào bù & 紙尿片 & t fi2 niu6 p'in2 & \\
\hline & Target 2 & cup & 杯子 & bēi zi & 杯 & pui1 & \\
\hline & Unr prime & box & 鱼 & yú & 韆鞦 & $\operatorname{cin} 1$ cau 1 & swing \\
\hline \multirow[t]{3}{*}{11} & Target 1 & shirt & 玻璃杯 & bō lí bēi & 玻璃杯 & bo1lei4 bui1 & glass \\
\hline & Target 2 & tree & 树 & shù & 樹 & Jy6 & \\
\hline & Unr prime & pillow & 枕头 & zhěn tou & 枕頭 & $\mathrm{t} \int \mathrm{em} 2 \mathrm{t}$ 'eu 4 & \\
\hline \multirow[t]{3}{*}{12} & Target 1 & trousers & 裤子 & kù zi & 褲 & fu3 & \\
\hline & Target 2 & blanket & 床毯 & chuáng tăn & 被 & p'ei5 & \\
\hline & Unr prime & bike & 自行车 & zì xíng chē & 單車 & $\tan 1 \mathrm{t} \int \varepsilon 1$ & \\
\hline \multirow[t]{3}{*}{13} & Target 1 & chips & 薯条 & shǔ tiáo & 薯條 & Jy4 t'iu5 & \\
\hline & & bin & 垃圾桶 & & 垃圾桶 & $\begin{array}{l}\text { lap6 fap3 } \\
\text { t"on2 }\end{array}$ & \\
\hline & Unr prime & & & yào shi & 游泳池 & $\begin{array}{l}\text { t'fan2 wIy6 } \\
\text { t } \int^{\prime \prime I} 4\end{array}$ & pool \\
\hline \multirow[t]{3}{*}{14} & Target 1 & cheese & 奶酪 & năi lào & 芝士 & tfil fi6 & \\
\hline & Target 2 & doll & 小娃娃 & xiăo wá wa & 公仔 & реи 4 & \\
\hline & Unr prime & soap & 肥皇 & féi zào & 番梘 & fan1 kan2 & \\
\hline \multirow[t]{3}{*}{15} & Target 1 & cow & 牛 & niú & 牛 & yeu4 & \\
\hline & Target 2 & bee & 蜜蜂 & mì fêng & 蜜蜂 & met6 fơn 1 & \\
\hline & Unr prime & highchair & 高脚登 & & 高腳発 & $\begin{array}{l}\text { kou1 kœk3 } \\
\text { tøy3 }\end{array}$ & \\
\hline \multirow{4}{*}{16} & & & 吸尘器 & & 吸塵機 & k'ep1 tf'en4 & \\
\hline & Target 1 & hoover & 叹土土各 & xī chén qì & & kei1 & \\
\hline & Target 2 & picture & 图片 & tú piàn & 圖片 & t'ou4 p'in 2 & \\
\hline & Unr prime & slide & 秋千 & qiū qiān & 滑梯 & wat6 t'vi1 & \\
\hline \multirow[t]{3}{*}{17} & Target 1 & car & 小轿车 & xiăo jiào chē & 汽車 & hei3 $\mathrm{t} \int " \varepsilon 1$ & \\
\hline & Target 2 & glasses & 眼镜 & yăn jìng & 眼鏡 & yan5 k\&n3 & \\
\hline & Unr prime & chicken & 鸡 & jī & 烏龜 & wu1 kweil & turtle \\
\hline \multirow[t]{3}{*}{18} & Target 1 & plane & 飞机 & fēi jī & 飛機 & feil kei1 & \\
\hline & Target 2 & bucket & 水桶 & shuǐ tǒng & 桶 & t'on2 & \\
\hline & Unr prime & food & 牙刷 & yá shuā & 鞋 & hai4 & shoe \\
\hline \multirow[t]{3}{*}{19} & Target 1 & coat & 外套 & wài tào & 魚 & jyu4 & fish \\
\hline & Target 2 & stairs & 楼梯 & lóu tī & 熊 & hợ 4 & bear \\
\hline & Unr prime & plate & 碟子 & dié zi & 碗 & wun2 & bowl \\
\hline \multirow[t]{3}{*}{20} & Target 1 & money & 钱 & qián & 金錢 & kem1 tf'in4 & \\
\hline & Target 2 & towel & 浴巾 & yù jīn & 沖涼毛巾 & $\begin{array}{l}\text { tf"uy } 1 \text { lœy } 4 \\
\text { mou } 4 \text { ken1 }\end{array}$ & \\
\hline & Unr prime & jacket & 短外衣 & duăn wài yī & 短褸 & tyn2 leu1 & \\
\hline
\end{tabular}

\begin{tabular}{|ll|l|lll|}
\cline { 3 - 5 } \multicolumn{1}{c|}{} & \multicolumn{1}{c|}{ English } & \multicolumn{3}{c|}{ Portuguese } \\
\cline { 2 - 5 } \multicolumn{1}{c|}{} & Word & Word & IPA & Alt \\
\hline 1 & Target 1 & bird & pássaro & 'fo:gəl & \\
& Target 2 & donkey & burro & 'e:zəl & shoe \\
& Unr prime & button & sapato & knəpf & \\
& & & &
\end{tabular}




\begin{tabular}{|c|c|c|c|c|c|}
\hline \multirow[t]{3}{*}{2} & Target 1 & bunny & coelho & ka'ni:nçən & \\
\hline & Target 2 & duck & pato & 'Entə & \\
\hline & Unr prime & juice & suco & zaft & \\
\hline \multirow[t]{3}{*}{3} & Target 1 & pig & urso & fvain & bear \\
\hline & Target 2 & squirrel & esquilo & aiç' hørnçən & \\
\hline & Unr prime & necklace & colar & 'halsketə & \\
\hline \multirow[t]{3}{*}{4} & Target 1 & horse & cavalo & pfe:rt & \\
\hline & Target 2 & butterfly & aranha & 'Smetərlın & spider \\
\hline & Unr prime & food & quarto & 'Esən & bedroom \\
\hline \multirow[t]{3}{*}{5} & Target 1 & tummy & barriga & baux & \\
\hline & Target 2 & spoon & colher & 'lœfəl & \\
\hline & Unr prime & hat & chapéu & 'mytsə & \\
\hline \multirow[t]{3}{*}{6} & Target 1 & cheek & bochecha & 'vayə & \\
\hline & Target 2 & drawer & gaveta & 'Ju:pla:də & \\
\hline & Unr prime & $\operatorname{dog}$ & cão & hont & \\
\hline \multirow[t]{3}{*}{7} & Target 1 & leg & perna & bain & \\
\hline & Target 2 & window & janela & 'fenstər & \\
\hline & Unr prime & monkey & peixe & 'afə & fish \\
\hline \multirow[t]{3}{*}{8} & Target 1 & dress & vestido & klait & \\
\hline & Target 2 & sink & pia & 'Jpy:1.ə & \\
\hline & Unr prime & dish & prato & ' 'yssəl & \\
\hline \multirow[t]{3}{*}{9} & Target 1 & jumper & ovo & pu'lo:vər & egg \\
\hline & Target 2 & watch & relógio & u:r & \\
\hline & Unr prime & peas & cadeira & tyr & door \\
\hline \multirow[t]{3}{*}{10} & Target 1 & nappy & fralda & 'vindəl & \\
\hline & Target 2 & cup & xicara & 'beçər & \\
\hline & Unr prime & box & balança & 'Jaukəl & swing \\
\hline \multirow[t]{3}{*}{11} & Target 1 & shirt & camisa & hemt & \\
\hline & Target 2 & tree & árvore & baum & \\
\hline & Unr prime & pillow & almofada & 'kisən & \\
\hline \multirow[t]{3}{*}{12} & Target 1 & trousers & calça & 'ho:zə & \\
\hline & Target 2 & blanket & manta & 'dekə & \\
\hline & Unr prime & bike & соро & 'fa:rra:t & glass \\
\hline \multirow[t]{3}{*}{13} & Target 1 & chips & batata frita & 'poməs & \\
\hline & Target 2 & bin & lixo & 'mylaimər & \\
\hline & Unr prime & lorry & caminhão & 'Slysəl & \\
\hline \multirow[t]{3}{*}{14} & Target 1 & cheese & queijo & 'ke:zə & \\
\hline & Target 2 & doll & boneca & 'рорә & \\
\hline & Unr prime & soap & meia & 'zaifə & sock \\
\hline 15 & Target 1 & cow & vaca & 'blu:mə & \\
\hline
\end{tabular}




\begin{tabular}{|c|c|c|c|c|c|}
\hline & Target 2 & bee & abelha & ' 'crə & \\
\hline & Unr prime & highchair & chaves & 'ho:xftu:l & key \\
\hline 16 & Target 1 & hoover & aspirador & ' ftaupzaugər & \\
\hline & Target 2 & picture & fotografia & bilt & \\
\hline & Unr prime & slide & escorregador & 'rotfo & \\
\hline 17 & Target 1 & car & cenoura & 'auto: & carrot \\
\hline & Target 2 & glasses & óculos & 'brila & \\
\hline & Unr prime & chicken & galinha & hu:n & \\
\hline 18 & Target 1 & plane & avião & 'flu:ktsork & \\
\hline & Target 2 & bucket & tesoura & 'aimər & scissors \\
\hline & Unr prime & food & escova de dentes & ke:ks & toothbrush \\
\hline 19 & Target 1 & coat & tigela & 'mantəl & bowl \\
\hline & Target 2 & stairs & escadas & 'trepə & \\
\hline & Unr prime & plate & rato & 'telər & mouse \\
\hline 20 & Target 1 & money & dinheiro & gelt & \\
\hline & Target 2 & towel & porta & 'hanttu:x & door \\
\hline & Unr prime & jacket & casaco & 'fla:ftsımər & \\
\hline
\end{tabular}


Appendix C: List of stimuli in Experiment 2

For each home language (Italian, French, Polish, Spanish, German, Dutch, Greek and

Mandarin), translation equivalents and IPA transcription of the words in each quintuplet

(from 1 to 20). A quintuplet is made of two pairs of related primes and targets, plus an

unrelated prime. Contrary to Experiment 1, all quintuplets are identical across all languages.

\begin{tabular}{|c|c|c|c|c|c|c|c|}
\hline & & $\begin{array}{l}\text { English } \\
\text { primes }\end{array}$ & targets & $\begin{array}{l}\text { Italian } \\
\text { primes } \\
\end{array}$ & IPA & targets & IPA \\
\hline 1 & $\begin{array}{l}\text { rel } \\
\text { rel } \\
\text { unrel }\end{array}$ & $\begin{array}{l}\text { table } \\
\text { dog } \\
\text { aeroplane }\end{array}$ & $\begin{array}{l}\text { chair } \\
\text { cat }\end{array}$ & $\begin{array}{l}\text { tavolo } \\
\text { cane } \\
\text { aereo } \\
\end{array}$ & $\begin{array}{l}\text { 'tavolo } \\
\text { 'kane } \\
\text { a'creo }\end{array}$ & $\begin{array}{l}\text { sedia } \\
\text { gatto }\end{array}$ & $\begin{array}{l}\text { 'sedja } \\
\text { 'gatto }\end{array}$ \\
\hline 2 & $\begin{array}{l}\text { rel } \\
\text { rel } \\
\text { unrel }\end{array}$ & $\begin{array}{l}\text { arm } \\
\text { spoon } \\
\text { duck }\end{array}$ & $\begin{array}{l}\text { leg } \\
\text { fork }\end{array}$ & $\begin{array}{l}\text { braccio } \\
\text { cucchiaio } \\
\text { papera }\end{array}$ & $\begin{array}{l}\text { 'bratto } \\
\text { kuk'kjajo } \\
\text { 'papera }\end{array}$ & $\begin{array}{l}\text { gambe } \\
\text { forchetta }\end{array}$ & $\begin{array}{l}\text { 'gambe } \\
\text { for'ketta }\end{array}$ \\
\hline 3 & $\begin{array}{l}\text { rel } \\
\text { rel } \\
\text { unrel }\end{array}$ & $\begin{array}{l}\text { sock } \\
\text { butter } \\
\text { TV } \\
\end{array}$ & $\begin{array}{l}\text { shoe } \\
\text { bread }\end{array}$ & $\begin{array}{l}\text { calze } \\
\text { burro } \\
\text { televisione }\end{array}$ & $\begin{array}{l}\text { 'kaltse } \\
\text { 'burro } \\
\text { televi'zjone }\end{array}$ & $\begin{array}{l}\text { scarpe } \\
\text { pane }\end{array}$ & $\begin{array}{l}\text { 'skarpe } \\
\text { 'pane }\end{array}$ \\
\hline 4 & $\begin{array}{l}\text { rel } \\
\text { rel } \\
\text { unrel }\end{array}$ & $\begin{array}{l}\text { toes } \\
\text { moon } \\
\text { house }\end{array}$ & $\begin{array}{l}\text { foot } \\
\text { sun }\end{array}$ & $\begin{array}{l}\text { dito del piede } \\
\text { luna } \\
\text { casa }\end{array}$ & $\begin{array}{l}\text { 'ditodel'pjede } \\
\text { 'luna } \\
\text { 'kaza }\end{array}$ & $\begin{array}{l}\text { piede } \\
\text { sole }\end{array}$ & $\begin{array}{l}\text { 'pjede } \\
\text { 'sole }\end{array}$ \\
\hline 5 & $\begin{array}{l}\text { rel } \\
\text { rel } \\
\text { unrel }\end{array}$ & $\begin{array}{l}\text { tongue } \\
\text { egg } \\
\text { doll }\end{array}$ & $\begin{array}{l}\text { mouth } \\
\text { chicken }\end{array}$ & $\begin{array}{l}\text { lingua } \\
\text { uovo } \\
\text { bambola }\end{array}$ & $\begin{array}{l}\text { 'lingwa } \\
\text { 'wovo } \\
\text { 'bambola }\end{array}$ & $\begin{array}{l}\text { bocca } \\
\text { pulcino }\end{array}$ & $\begin{array}{l}\text { 'bokka } \\
\text { pul'tfino }\end{array}$ \\
\hline 6 & $\begin{array}{l}\text { rel } \\
\text { rel } \\
\text { unrel }\end{array}$ & $\begin{array}{l}\text { hand } \\
\text { tiger } \\
\text { stairs }\end{array}$ & $\begin{array}{l}\text { finger } \\
\text { lion }\end{array}$ & $\begin{array}{l}\text { mano } \\
\text { tigre } \\
\text { scala }\end{array}$ & $\begin{array}{l}\text { 'mano } \\
\text { 'tigre } \\
\text { 'skala }\end{array}$ & $\begin{array}{l}\text { dito } \\
\text { leone }\end{array}$ & $\begin{array}{l}\text { 'dito } \\
\text { le'one }\end{array}$ \\
\hline 7 & $\begin{array}{l}\text { rel } \\
\text { rel } \\
\text { unrel }\end{array}$ & $\begin{array}{l}\text { glasses } \\
\text { bus } \\
\text { monkey } \\
\end{array}$ & $\begin{array}{l}\text { eyes } \\
\text { car }\end{array}$ & $\begin{array}{l}\text { occhiali } \\
\text { autobus } \\
\text { scimmia } \\
\end{array}$ & $\begin{array}{l}\text { ok'kjali } \\
\text { 'awtobus } \\
\text { 'Jimmja } \\
\end{array}$ & $\begin{array}{l}\text { occhio } \\
\text { automobile }\end{array}$ & $\begin{array}{l}\text { 'okkjo } \\
\text { awto'mobile }\end{array}$ \\
\hline 8 & $\begin{array}{l}\text { rel } \\
\text { rel } \\
\text { unrel }\end{array}$ & $\begin{array}{l}\text { coat } \\
\text { elephant } \\
\text { bike }\end{array}$ & $\begin{array}{l}\text { hat } \\
\text { mouse }\end{array}$ & $\begin{array}{l}\text { cappotto } \\
\text { elefante } \\
\text { bicicletta }\end{array}$ & $\begin{array}{l}\text { kap'potto } \\
\text { ele'fante } \\
\text { bitfi'kletta }\end{array}$ & $\begin{array}{l}\text { cappello } \\
\text { topo }\end{array}$ & $\begin{array}{l}\text { kap'pello } \\
\text { 'topo }\end{array}$ \\
\hline 9 & $\begin{array}{l}\text { rel } \\
\text { rel } \\
\text { unrel }\end{array}$ & $\begin{array}{l}\text { ear } \\
\text { window } \\
\text { boat }\end{array}$ & $\begin{array}{l}\text { nose } \\
\text { door }\end{array}$ & $\begin{array}{l}\text { orecchio } \\
\text { finestra } \\
\text { barca }\end{array}$ & $\begin{array}{l}\text { o'rekkjo } \\
\text { fi'nestra } \\
\text { 'barka }\end{array}$ & $\begin{array}{l}\text { naso } \\
\text { porta }\end{array}$ & $\begin{array}{l}\text { 'nazo } \\
\text { 'porta }\end{array}$ \\
\hline 10 & $\begin{array}{l}\text { rel } \\
\text { rel }\end{array}$ & $\begin{array}{l}\text { park } \\
\text { balloon }\end{array}$ & $\begin{array}{l}\text { tree } \\
\text { ball }\end{array}$ & $\begin{array}{l}\text { parco } \\
\text { palloncino }\end{array}$ & $\begin{array}{l}\text { 'parko } \\
\text { pallon'tyino }\end{array}$ & $\begin{array}{l}\text { albero } \\
\text { palla }\end{array}$ & $\begin{array}{l}\text { 'albero } \\
\text { 'palla }\end{array}$ \\
\hline
\end{tabular}




\begin{tabular}{|c|c|c|c|c|c|c|c|}
\hline & unrel & scissors & & forbici & 'forbitfi & & \\
\hline 11 & $\begin{array}{l}\text { rel } \\
\text { rel } \\
\text { unrel }\end{array}$ & $\begin{array}{l}\text { swing } \\
\text { cereal } \\
\text { penguin }\end{array}$ & $\begin{array}{l}\text { slide } \\
\text { bowl }\end{array}$ & $\begin{array}{l}\text { altalena } \\
\text { cereali } \\
\text { pinguino }\end{array}$ & $\begin{array}{l}\text { alta'lena } \\
\text { tere'ali } \\
\text { pin'gwino }\end{array}$ & $\begin{array}{l}\text { scivolo } \\
\text { scodella }\end{array}$ & $\begin{array}{l}\text { 'Sivolo } \\
\text { sko'della }\end{array}$ \\
\hline 12 & $\begin{array}{l}\text { rel } \\
\text { rel } \\
\text { unrel }\end{array}$ & $\begin{array}{l}\text { apple } \\
\text { fish } \\
\text { potty }\end{array}$ & $\begin{array}{l}\text { banana } \\
\text { frog }\end{array}$ & $\begin{array}{l}\text { mela } \\
\text { pesciolino } \\
\text { vasino }\end{array}$ & $\begin{array}{l}\text { 'mela } \\
\text { pe } \iint o^{\prime} l i n o \\
\text { va"zino }\end{array}$ & $\begin{array}{l}\text { banana } \\
\text { rana }\end{array}$ & $\begin{array}{l}\text { ba'nana } \\
\text { 'rana }\end{array}$ \\
\hline 13 & $\begin{array}{l}\text { rel } \\
\text { rel } \\
\text { unrel }\end{array}$ & $\begin{array}{l}\text { cake } \\
\text { sky } \\
\text { pillow }\end{array}$ & $\begin{array}{l}\text { biscuit } \\
\text { bird }\end{array}$ & $\begin{array}{l}\text { torta } \\
\text { cielo } \\
\text { cuscino }\end{array}$ & 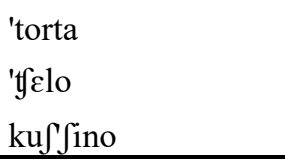 & $\begin{array}{l}\text { biscotto } \\
\text { uccellino }\end{array}$ & $\begin{array}{l}\text { bis'kotto } \\
\text { uttfel'lino }\end{array}$ \\
\hline 14 & $\begin{array}{l}\text { rel } \\
\text { rel } \\
\text { unrel }\end{array}$ & $\begin{array}{l}\text { carrot } \\
\text { button } \\
\text { soap }\end{array}$ & $\begin{array}{l}\text { peas } \\
\text { trousers }\end{array}$ & $\begin{array}{l}\text { carote } \\
\text { bottone } \\
\text { sapone }\end{array}$ & $\begin{array}{l}\text { ka'rote } \\
\text { bot'tone } \\
\text { sa"pone }\end{array}$ & $\begin{array}{l}\text { piselli } \\
\text { pantaloni }\end{array}$ & $\begin{array}{l}\text { pi'sclli } \\
\text { panta'loni }\end{array}$ \\
\hline 15 & $\begin{array}{l}\text { rel } \\
\text { rel } \\
\text { unrel }\end{array}$ & $\begin{array}{l}\text { sheep } \\
\text { lorry } \\
\text { money }\end{array}$ & $\begin{array}{l}\text { cow } \\
\text { train }\end{array}$ & $\begin{array}{l}\text { pecora } \\
\text { camion } \\
\text { soldi }\end{array}$ & $\begin{array}{l}\text { 'pekora } \\
\text { 'kamjon } \\
\text { 'soldi }\end{array}$ & $\begin{array}{l}\text { mucca } \\
\text { treno }\end{array}$ & $\begin{array}{l}\text { 'mukka } \\
\text { 'treno }\end{array}$ \\
\hline 16 & $\begin{array}{l}\text { rel } \\
\text { rel } \\
\text { unrel }\end{array}$ & $\begin{array}{l}\text { bee } \\
\text { cup } \\
\text { bubble }\end{array}$ & $\begin{array}{l}\text { flower } \\
\text { milk }\end{array}$ & $\begin{array}{l}\text { ape } \\
\text { tazza } \\
\text { bolle }\end{array}$ & $\begin{array}{l}\text { 'ape } \\
\text { 'tattsa } \\
\text { 'bolle }\end{array}$ & $\begin{array}{l}\text { fiore } \\
\text { latte }\end{array}$ & $\begin{array}{l}\text { 'fjore } \\
\text { 'latte }\end{array}$ \\
\hline 17 & $\begin{array}{l}\text { rel } \\
\text { rel } \\
\text { unrel }\end{array}$ & $\begin{array}{l}\text { nappy } \\
\text { picture } \\
\text { giraffe } \\
\end{array}$ & $\begin{array}{l}\text { bib } \\
\text { book }\end{array}$ & $\begin{array}{l}\text { pannolino } \\
\text { foto } \\
\text { giraffa }\end{array}$ & $\begin{array}{l}\text { panno'lino } \\
\text { 'foto } \\
\text { dji'raffa }\end{array}$ & $\begin{array}{l}\text { bavaglino } \\
\text { libro }\end{array}$ & $\begin{array}{l}\text { bava K'Kino } \\
\text { 'libro }\end{array}$ \\
\hline 18 & $\begin{array}{l}\text { rel } \\
\text { rel } \\
\text { unrel }\end{array}$ & $\begin{array}{l}\text { orange } \\
\text { pyjamas } \\
\text { towel }\end{array}$ & $\begin{array}{l}\text { cheese } \\
\text { bed }\end{array}$ & $\begin{array}{l}\text { arancia } \\
\text { pigiama } \\
\text { asciugamano }\end{array}$ & 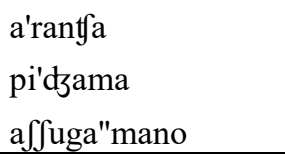 & $\begin{array}{l}\text { formaggio } \\
\text { letto }\end{array}$ & $\begin{array}{l}\text { for'maddjo } \\
\text { 'letto }\end{array}$ \\
\hline 19 & $\begin{array}{l}\text { rel } \\
\text { rel } \\
\text { unrel }\end{array}$ & $\begin{array}{l}\text { plate } \\
\text { toothbrush } \\
\text { horse }\end{array}$ & $\begin{array}{l}\text { bottle } \\
\text { bath }\end{array}$ & $\begin{array}{l}\text { piatto } \\
\text { spazzolino da denti } \\
\text { cavallo }\end{array}$ & $\begin{array}{l}\text { 'pjatto } \\
\text { spattso'linoda'denti } \\
\text { ka"vallo }\end{array}$ & $\begin{array}{l}\text { bottiglia } \\
\text { vasca da bagno }\end{array}$ & $\begin{array}{l}\text { bot'tiאKa } \\
\text { vaskada'banpo }\end{array}$ \\
\hline 20 & $\begin{array}{l}\text { rel } \\
\text { rel } \\
\text { unrel }\end{array}$ & $\begin{array}{l}\text { toys } \\
\text { water } \\
\text { key }\end{array}$ & $\begin{array}{l}\text { blocks } \\
\text { juice }\end{array}$ & $\begin{array}{l}\text { giocattolo } \\
\text { acqua } \\
\text { chiave }\end{array}$ & $\begin{array}{l}\text { dzo'kattolo } \\
\text { 'akkwa } \\
\text { 'kjave }\end{array}$ & $\begin{array}{l}\text { cubi } \\
\text { succo }\end{array}$ & $\begin{array}{l}\text { 'kubi } \\
\text { 'sukko }\end{array}$ \\
\hline
\end{tabular}

\begin{tabular}{|c|c|c|c|c|c|c|c|}
\hline & & $\begin{array}{l}\text { English } \\
\text { primes }\end{array}$ & targets & $\begin{array}{l}\text { French } \\
\text { primes }\end{array}$ & IPA & targets & IPA \\
\hline 1 & $\begin{array}{l}\text { rel } \\
\text { rel } \\
\text { unrel }\end{array}$ & $\begin{array}{l}\text { table } \\
\text { dog } \\
\text { aeroplane }\end{array}$ & $\begin{array}{l}\text { chair } \\
\text { cat }\end{array}$ & $\begin{array}{l}\text { table } \\
\text { chien } \\
\text { avion }\end{array}$ & 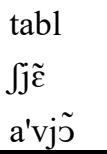 & $\begin{array}{l}\text { chaise } \\
\text { chat }\end{array}$ & $\begin{array}{l}\int \varepsilon z \\
\int a\end{array}$ \\
\hline 2 & $\begin{array}{l}\text { rel } \\
\text { rel } \\
\text { unrel }\end{array}$ & $\begin{array}{l}\text { arm } \\
\text { spoon } \\
\text { duck } \\
\end{array}$ & $\begin{array}{l}\text { leg } \\
\text { fork }\end{array}$ & $\begin{array}{l}\text { bras } \\
\text { cuillère } \\
\text { canard }\end{array}$ & $\begin{array}{l}\text { вьа } \\
\text { кці'jєь } \\
\text { ka'naь } \\
\end{array}$ & $\begin{array}{l}\text { jambe } \\
\text { fourchette }\end{array}$ & $\begin{array}{l}\text { zãb } \\
\text { fus'fet }\end{array}$ \\
\hline 3 & $\begin{array}{l}\text { rel } \\
\text { rel } \\
\text { unrel }\end{array}$ & $\begin{array}{l}\text { sock } \\
\text { butter } \\
\text { TV }\end{array}$ & $\begin{array}{l}\text { shoe } \\
\text { bread }\end{array}$ & $\begin{array}{l}\text { chaussettes } \\
\text { beurre } \\
\text { télé }\end{array}$ & $\begin{array}{l}\text { fo'set } \\
\text { bœь } \\
\text { te'le }\end{array}$ & $\begin{array}{l}\text { chaussure } \\
\text { pain }\end{array}$ & 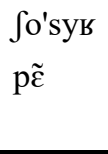 \\
\hline
\end{tabular}




\begin{tabular}{|c|c|c|c|c|c|c|c|}
\hline 4 & $\begin{array}{l}\text { rel } \\
\text { rel } \\
\text { unrel }\end{array}$ & $\begin{array}{l}\text { toes } \\
\text { moon } \\
\text { house }\end{array}$ & $\begin{array}{l}\text { foot } \\
\text { sun }\end{array}$ & $\begin{array}{l}\text { doigt de pied } \\
\text { lune } \\
\text { maison }\end{array}$ & $\begin{array}{l}\text { dwad'pje } \\
\text { lyn } \\
\text { me'zõ }\end{array}$ & $\begin{array}{l}\text { pied } \\
\text { soleil }\end{array}$ & $\begin{array}{l}\text { pje } \\
\text { so'lcj }\end{array}$ \\
\hline 5 & $\begin{array}{l}\text { rel } \\
\text { rel } \\
\text { unrel }\end{array}$ & $\begin{array}{l}\text { tongue } \\
\text { egg } \\
\text { doll } \\
\end{array}$ & $\begin{array}{l}\text { mouth } \\
\text { chicken }\end{array}$ & $\begin{array}{l}\text { langue } \\
\text { oeuf } \\
\text { poupée }\end{array}$ & $\begin{array}{l}\text { lãg } \\
\text { œf } \\
\text { pu'pe }\end{array}$ & $\begin{array}{l}\text { bouche } \\
\text { poule }\end{array}$ & $\begin{array}{l}\mathrm{bu} \int \\
\text { pul }\end{array}$ \\
\hline 6 & $\begin{array}{l}\text { rel } \\
\text { rel } \\
\text { unrel }\end{array}$ & $\begin{array}{l}\text { hand } \\
\text { tiger } \\
\text { stairs }\end{array}$ & $\begin{array}{l}\text { finger } \\
\text { lion }\end{array}$ & $\begin{array}{l}\text { main } \\
\text { tigre } \\
\text { escalier }\end{array}$ & 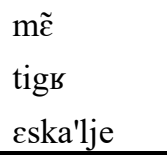 & $\begin{array}{l}\text { doigt } \\
\text { lion }\end{array}$ & $\begin{array}{l}\text { dwa } \\
\text { ljõ }\end{array}$ \\
\hline 7 & $\begin{array}{l}\text { rel } \\
\text { rel } \\
\text { unrel }\end{array}$ & $\begin{array}{l}\text { glasses } \\
\text { bus } \\
\text { monkey }\end{array}$ & $\begin{array}{l}\text { eyes } \\
\text { car }\end{array}$ & $\begin{array}{l}\text { lunettes } \\
\text { bus } \\
\text { singe }\end{array}$ & $\begin{array}{l}\text { ly'net } \\
\text { bys } \\
\text { sẽz } \\
\end{array}$ & $\begin{array}{l}\text { yeux } \\
\text { voiture }\end{array}$ & $\begin{array}{l}\text { jø } \\
\text { vwa'tys }\end{array}$ \\
\hline 8 & $\begin{array}{l}\text { rel } \\
\text { rel } \\
\text { unrel }\end{array}$ & $\begin{array}{l}\text { coat } \\
\text { elephant } \\
\text { bike }\end{array}$ & $\begin{array}{l}\text { hat } \\
\text { mouse }\end{array}$ & $\begin{array}{l}\text { manteau } \\
\text { éléphant } \\
\text { vélo }\end{array}$ & $\begin{array}{l}\text { mã'to } \\
\text { ele'fã } \\
\text { ve'lo }\end{array}$ & $\begin{array}{l}\text { chapeau } \\
\text { souris }\end{array}$ & $\begin{array}{l}\text { Sa'po } \\
\text { su'ьі }\end{array}$ \\
\hline 9 & $\begin{array}{l}\text { rel } \\
\text { rel } \\
\text { unrel }\end{array}$ & $\begin{array}{l}\text { ear } \\
\text { window } \\
\text { boat }\end{array}$ & $\begin{array}{l}\text { nose } \\
\text { door }\end{array}$ & $\begin{array}{l}\text { oreille } \\
\text { fenêtre } \\
\text { bateau }\end{array}$ & $\begin{array}{l}\text { о'ьєј } \\
\text { fə'nєtв } \\
\text { ba'to } \\
\end{array}$ & $\begin{array}{l}\text { nez } \\
\text { porte }\end{array}$ & $\begin{array}{l}\text { ne } \\
\text { ровt }\end{array}$ \\
\hline 10 & $\begin{array}{l}\text { rel } \\
\text { rel } \\
\text { unrel }\end{array}$ & $\begin{array}{l}\text { park } \\
\text { balloon } \\
\text { scissors }\end{array}$ & $\begin{array}{l}\text { tree } \\
\text { ball }\end{array}$ & $\begin{array}{l}\text { parc } \\
\text { ballon } \\
\text { ciseaux }\end{array}$ & $\begin{array}{l}\text { pask } \\
\text { ba'ló } \\
\text { si'zo } \\
\end{array}$ & $\begin{array}{l}\text { arbre } \\
\text { balle }\end{array}$ & $\begin{array}{l}\text { авьь } \\
\text { bal }\end{array}$ \\
\hline 11 & $\begin{array}{l}\text { rel } \\
\text { rel } \\
\text { unrel }\end{array}$ & $\begin{array}{l}\text { swing } \\
\text { cereal } \\
\text { penguin }\end{array}$ & $\begin{array}{l}\text { slide } \\
\text { bowl }\end{array}$ & $\begin{array}{l}\text { balançoire } \\
\text { céréales } \\
\text { pingouin }\end{array}$ & 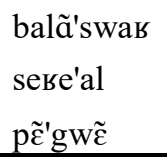 & $\begin{array}{l}\text { toboggan } \\
\text { bol }\end{array}$ & $\begin{array}{l}\text { tobo'gã } \\
\text { bol }\end{array}$ \\
\hline 12 & $\begin{array}{l}\text { rel } \\
\text { rel } \\
\text { unrel }\end{array}$ & $\begin{array}{l}\text { apple } \\
\text { fish } \\
\text { potty }\end{array}$ & $\begin{array}{l}\text { banana } \\
\text { frog }\end{array}$ & $\begin{array}{l}\text { pomme } \\
\text { poisson } \\
\text { pot }\end{array}$ & $\begin{array}{l}\text { pom } \\
\text { pwa's ̃ } \\
\text { po }\end{array}$ & $\begin{array}{l}\text { banane } \\
\text { grenouille }\end{array}$ & $\begin{array}{l}\text { ba'nan } \\
\text { gьә'nuj }\end{array}$ \\
\hline 13 & $\begin{array}{l}\text { rel } \\
\text { rel } \\
\text { unrel }\end{array}$ & $\begin{array}{l}\text { cake } \\
\text { sky } \\
\text { pillow }\end{array}$ & $\begin{array}{l}\text { biscuit } \\
\text { bird }\end{array}$ & $\begin{array}{l}\text { gateau } \\
\text { ciel } \\
\text { oreiller }\end{array}$ & $\begin{array}{l}\text { ga'to } \\
\text { sjel } \\
\text { ове'je }\end{array}$ & $\begin{array}{l}\text { petits gateaux } \\
\text { oiseau }\end{array}$ & $\begin{array}{l}\text { pətiga'to } \\
\text { wa'zo }\end{array}$ \\
\hline 14 & $\begin{array}{l}\text { rel } \\
\text { rel } \\
\text { unrel }\end{array}$ & $\begin{array}{l}\text { carrot } \\
\text { button } \\
\text { soap } \\
\end{array}$ & $\begin{array}{l}\text { peas } \\
\text { trousers }\end{array}$ & $\begin{array}{l}\text { carotte } \\
\text { boutons } \\
\text { savon }\end{array}$ & $\begin{array}{l}\text { ka'воt } \\
\text { bu'tõ } \\
\text { sa'ṽ̃ }\end{array}$ & $\begin{array}{l}\text { petits pois } \\
\text { pantalon }\end{array}$ & $\begin{array}{l}\text { pəti'pwa } \\
\text { pãta'ló }\end{array}$ \\
\hline 15 & $\begin{array}{l}\text { rel } \\
\text { rel } \\
\text { unrel }\end{array}$ & $\begin{array}{l}\text { sheep } \\
\text { lorry } \\
\text { money }\end{array}$ & $\begin{array}{l}\text { cow } \\
\text { train }\end{array}$ & $\begin{array}{l}\text { mouton } \\
\text { camion } \\
\text { argent }\end{array}$ & 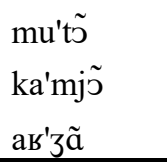 & $\begin{array}{l}\text { vache } \\
\text { train }\end{array}$ & $\begin{array}{l}\mathrm{va} \int \\
\text { tв } \tilde{\varepsilon}\end{array}$ \\
\hline 16 & $\begin{array}{l}\text { rel } \\
\text { rel } \\
\text { unrel }\end{array}$ & $\begin{array}{l}\text { bee } \\
\text { cup } \\
\text { bubble }\end{array}$ & $\begin{array}{l}\text { flower } \\
\text { milk }\end{array}$ & $\begin{array}{l}\text { abeille } \\
\text { tasse } \\
\text { bulles }\end{array}$ & $\begin{array}{l}\text { a'bcj } \\
\text { tas } \\
\text { byl }\end{array}$ & $\begin{array}{l}\text { fleur } \\
\text { lait }\end{array}$ & $\begin{array}{l}\text { flœь } \\
\text { le }\end{array}$ \\
\hline 17 & $\begin{array}{l}\text { rel } \\
\text { rel } \\
\text { unrel }\end{array}$ & $\begin{array}{l}\text { nappy } \\
\text { picture } \\
\text { giraffe }\end{array}$ & $\begin{array}{l}\text { bib } \\
\text { book }\end{array}$ & $\begin{array}{l}\text { couche } \\
\text { photo } \\
\text { girafe }\end{array}$ & $\begin{array}{l}\mathrm{ku} \int \\
\text { fo'to } \\
\text { zi'saf }\end{array}$ & $\begin{array}{l}\text { bavoir } \\
\text { livre }\end{array}$ & $\begin{array}{l}\text { ba'vwas } \\
\text { livs }\end{array}$ \\
\hline 18 & $\begin{array}{l}\text { rel } \\
\text { rel }\end{array}$ & $\begin{array}{l}\text { orange } \\
\text { pyjamas }\end{array}$ & $\begin{array}{l}\text { cheese } \\
\text { bed }\end{array}$ & $\begin{array}{l}\text { orange } \\
\text { pyjama }\end{array}$ & $\begin{array}{l}\text { о'ьа̃з } \\
\text { рiza'ma }\end{array}$ & $\begin{array}{l}\text { fromage } \\
\text { lit }\end{array}$ & $\begin{array}{l}\text { fво'maz } \\
\text { li }\end{array}$ \\
\hline
\end{tabular}




\begin{tabular}{|c|c|c|c|c|c|c|c|}
\hline & unrel & towel & & serviette & sعь'vjعt & & \\
\hline 19 & $\begin{array}{l}\text { rel } \\
\text { rel } \\
\text { unrel }\end{array}$ & $\begin{array}{l}\text { plate } \\
\text { toothbrush } \\
\text { horse }\end{array}$ & $\begin{array}{l}\text { bottle } \\
\text { bath }\end{array}$ & $\begin{array}{l}\text { assiette } \\
\text { brosse à dent } \\
\text { cheval }\end{array}$ & $\begin{array}{l}\text { a'sjet } \\
\text { ьвэsa'dã } \\
\text { Sə'val }\end{array}$ & $\begin{array}{l}\text { bouteille } \\
\text { baignoire }\end{array}$ & $\begin{array}{l}\text { bu'tcj } \\
\text { be'nwas }\end{array}$ \\
\hline 20 & $\begin{array}{l}\text { rel } \\
\text { rel } \\
\text { unrel }\end{array}$ & $\begin{array}{l}\text { toys } \\
\text { water } \\
\text { key }\end{array}$ & $\begin{array}{l}\text { blocks } \\
\text { juice }\end{array}$ & $\begin{array}{l}\text { jouet } \\
\text { eau } \\
\text { clefs }\end{array}$ & $\begin{array}{l}3 w \varepsilon \\
\text { o } \\
\text { kle }\end{array}$ & $\begin{array}{l}\text { cube } \\
\text { jus de fruit }\end{array}$ & $\begin{array}{l}\text { kyb } \\
\text { 3уd'fьчi }\end{array}$ \\
\hline
\end{tabular}

\begin{tabular}{|c|c|c|c|c|c|c|c|}
\hline & & $\begin{array}{l}\text { English } \\
\text { primes }\end{array}$ & targets & $\begin{array}{l}\text { Polish } \\
\text { primes }\end{array}$ & IPA & targets & IPA \\
\hline 1 & $\begin{array}{l}\text { rel } \\
\text { rel } \\
\text { unrel }\end{array}$ & $\begin{array}{l}\text { table } \\
\text { dog } \\
\text { aeroplane }\end{array}$ & $\begin{array}{l}\text { chair } \\
\text { cat }\end{array}$ & $\begin{array}{l}\text { stol } \\
\text { pies } \\
\text { samolot }\end{array}$ & $\begin{array}{l}\text { stuw } \\
\mathrm{p}^{\mathrm{j}} \varepsilon \mathrm{s} \\
\text { sa'molot }\end{array}$ & $\begin{array}{l}\text { krzeslo } \\
\text { kot }\end{array}$ & $\begin{array}{l}\text { 'k } \int \varepsilon s w o \\
\text { kot }\end{array}$ \\
\hline 2 & $\begin{array}{l}\text { rel } \\
\text { rel } \\
\text { unrel }\end{array}$ & $\begin{array}{l}\text { arm } \\
\text { spoon } \\
\text { duck } \\
\end{array}$ & $\begin{array}{l}\text { leg } \\
\text { fork }\end{array}$ & $\begin{array}{l}\text { ramie } \\
\text { lyzka } \\
\text { kaczka }\end{array}$ & $\begin{array}{l}\text { 'ramic } \\
\text { 'wifka } \\
\text { 'katfka }\end{array}$ & $\begin{array}{l}\text { noga } \\
\text { widelec }\end{array}$ & $\begin{array}{l}\text { 'noga } \\
\text { vi'delets }\end{array}$ \\
\hline 3 & $\begin{array}{l}\text { rel } \\
\text { rel } \\
\text { unrel }\end{array}$ & $\begin{array}{l}\text { sock } \\
\text { butter } \\
\text { TV }\end{array}$ & $\begin{array}{l}\text { shoe } \\
\text { bread }\end{array}$ & $\begin{array}{l}\text { skarpetki } \\
\text { maslo } \\
\text { telewizor }\end{array}$ & $\begin{array}{l}\text { skar'petki } \\
\text { 'maswo } \\
\text { tele'vizor }\end{array}$ & $\begin{array}{l}\text { buty } \\
\text { chleb }\end{array}$ & $\begin{array}{l}\text { 'buti } \\
\text { xlep }\end{array}$ \\
\hline 4 & $\begin{array}{l}\text { rel } \\
\text { rel } \\
\text { unrel }\end{array}$ & $\begin{array}{l}\text { toes } \\
\text { moon } \\
\text { house } \\
\end{array}$ & $\begin{array}{l}\text { foot } \\
\text { sun }\end{array}$ & $\begin{array}{l}\text { palec } \\
\text { ksiezyc } \\
\text { dom }\end{array}$ & $\begin{array}{l}\text { 'palets } \\
\text { 'k6ẽzits } \\
\text { dom }\end{array}$ & $\begin{array}{l}\text { stopa } \\
\text { slonce }\end{array}$ & $\begin{array}{l}\text { 'stopa } \\
\text { 'swojtse }\end{array}$ \\
\hline 5 & $\begin{array}{l}\text { rel } \\
\text { rel } \\
\text { unrel }\end{array}$ & $\begin{array}{l}\text { tongue } \\
\text { egg } \\
\text { doll }\end{array}$ & $\begin{array}{l}\text { mouth } \\
\text { chicken }\end{array}$ & $\begin{array}{l}\text { jezyk } \\
\text { jajko } \\
\text { lalka } \\
\end{array}$ & $\begin{array}{l}\text { 'jẽzik } \\
\text { 'jajko } \\
\text { 'lalka } \\
\end{array}$ & $\begin{array}{l}\text { buzia } \\
\text { kura }\end{array}$ & $\begin{array}{l}\text { 'buza } \\
\text { 'kura }\end{array}$ \\
\hline 6 & $\begin{array}{l}\text { rel } \\
\text { rel } \\
\text { unrel }\end{array}$ & $\begin{array}{l}\text { hand } \\
\text { tiger } \\
\text { stairs }\end{array}$ & $\begin{array}{l}\text { finger } \\
\text { lion }\end{array}$ & $\begin{array}{l}\text { reka } \\
\text { tygrys } \\
\text { schody }\end{array}$ & $\begin{array}{l}\text { 'reyka } \\
\text { 'tigris } \\
\text { 'sxodi }\end{array}$ & $\begin{array}{l}\text { palec } \\
\text { lew }\end{array}$ & $\begin{array}{l}\text { 'palets } \\
\text { lef }\end{array}$ \\
\hline 7 & $\begin{array}{l}\text { rel } \\
\text { rel } \\
\text { unrel }\end{array}$ & $\begin{array}{l}\text { glasses } \\
\text { bus } \\
\text { monkey }\end{array}$ & $\begin{array}{l}\text { eyes } \\
\text { car }\end{array}$ & $\begin{array}{l}\text { okulary } \\
\text { autobus } \\
\text { malpa }\end{array}$ & $\begin{array}{l}\text { Poku'lari } \\
\text { Pau'tobus } \\
\text { 'mawpa }\end{array}$ & $\begin{array}{l}\text { oko } \\
\text { auto }\end{array}$ & $\begin{array}{l}\text { 'Poko } \\
\text { 'Pauto }\end{array}$ \\
\hline 8 & $\begin{array}{l}\text { rel } \\
\text { rel } \\
\text { unrel }\end{array}$ & $\begin{array}{l}\text { coat } \\
\text { elephant } \\
\text { bike }\end{array}$ & $\begin{array}{l}\text { hat } \\
\text { mouse }\end{array}$ & $\begin{array}{l}\text { paszcz } \\
\text { slon } \\
\text { rower }\end{array}$ & $\begin{array}{l}\text { pwaft } \\
\text { swoj } \\
\text { 'rover }\end{array}$ & $\begin{array}{l}\text { kapelusz } \\
\text { myszka }\end{array}$ & $\begin{array}{l}\text { ka'peluf } \\
\text { 'mifka }\end{array}$ \\
\hline 9 & $\begin{array}{l}\text { rel } \\
\text { rel } \\
\text { unrel }\end{array}$ & $\begin{array}{l}\text { ear } \\
\text { window } \\
\text { boat }\end{array}$ & $\begin{array}{l}\text { nose } \\
\text { door }\end{array}$ & $\begin{array}{l}\text { ucho } \\
\text { okno } \\
\text { statek }\end{array}$ & $\begin{array}{l}\text { 'Puxo } \\
\text { 'Pokno } \\
\text { 'statck } \\
\end{array}$ & $\begin{array}{l}\text { nos } \\
\text { drzwi }\end{array}$ & $\begin{array}{l}\text { nos } \\
\text { dzvi }\end{array}$ \\
\hline 10 & $\begin{array}{l}\text { rel } \\
\text { rel } \\
\text { unrel }\end{array}$ & $\begin{array}{l}\text { park } \\
\text { balloon } \\
\text { scissors }\end{array}$ & $\begin{array}{l}\text { tree } \\
\text { ball }\end{array}$ & $\begin{array}{l}\text { park } \\
\text { balonik } \\
\text { nozyczki }\end{array}$ & $\begin{array}{l}\text { park } \\
\text { ba'lojik } \\
\text { no'zitgki }\end{array}$ & $\begin{array}{l}\text { drzewo } \\
\text { pilka }\end{array}$ & $\begin{array}{l}\text { 'dzevo } \\
\text { 'piwka }\end{array}$ \\
\hline
\end{tabular}




\begin{tabular}{|c|c|c|c|c|c|c|c|}
\hline 11 & $\begin{array}{l}\text { rel } \\
\text { rel } \\
\text { unrel }\end{array}$ & $\begin{array}{l}\text { swing } \\
\text { cereal } \\
\text { penguin }\end{array}$ & $\begin{array}{l}\text { slide } \\
\text { bowl }\end{array}$ & $\begin{array}{l}\text { hustawka } \\
\text { platki zbozowe } \\
\text { pingwin }\end{array}$ & $\begin{array}{l}\text { hu'ctafka } \\
\text { pwatkizbo'zove } \\
\text { 'pingvin }\end{array}$ & $\begin{array}{l}\text { slizgawka } \\
\text { miseczka }\end{array}$ & $\begin{array}{l}\text { cliz'gafka } \\
\text { mi'setgka }\end{array}$ \\
\hline 12 & $\begin{array}{l}\text { rel } \\
\text { rel } \\
\text { unrel }\end{array}$ & $\begin{array}{l}\text { apple } \\
\text { fish } \\
\text { potty }\end{array}$ & $\begin{array}{l}\text { banana } \\
\text { frog }\end{array}$ & $\begin{array}{l}\text { jablko } \\
\text { ryba } \\
\text { nocnik }\end{array}$ & $\begin{array}{l}\text { 'jabwko } \\
\text { 'riba } \\
\text { 'notsnik }\end{array}$ & $\begin{array}{l}\text { banan } \\
\text { zaba }\end{array}$ & $\begin{array}{l}\text { 'banan } \\
\text { 'zaba }\end{array}$ \\
\hline 13 & $\begin{array}{l}\text { rel } \\
\text { rel } \\
\text { unrel }\end{array}$ & $\begin{array}{l}\text { cake } \\
\text { sky } \\
\text { pillow }\end{array}$ & $\begin{array}{l}\text { biscuit } \\
\text { bird }\end{array}$ & $\begin{array}{l}\text { ciasto } \\
\text { niebo } \\
\text { poduszka }\end{array}$ & $\begin{array}{l}\text { 'tcasto } \\
\text { 'nebo } \\
\text { po'dufka }\end{array}$ & $\begin{array}{l}\text { herbatnik } \\
\text { ptaszek }\end{array}$ & $\begin{array}{l}\text { her'batnik } \\
\text { 'pta } \varepsilon k\end{array}$ \\
\hline 14 & $\begin{array}{l}\text { rel } \\
\text { rel } \\
\text { unrel }\end{array}$ & $\begin{array}{l}\text { carrot } \\
\text { button } \\
\text { soap } \\
\end{array}$ & $\begin{array}{l}\text { peas } \\
\text { trousers }\end{array}$ & $\begin{array}{l}\text { marchewki } \\
\text { guzik } \\
\text { mydlo }\end{array}$ & $\begin{array}{l}\text { mar'xefki } \\
\text { 'guzik } \\
\text { 'midwo } \\
\end{array}$ & $\begin{array}{l}\text { groszek } \\
\text { spodnie }\end{array}$ & $\begin{array}{l}\text { 'gro } \varepsilon k \mathrm{k} \\
\text { 'spodne }\end{array}$ \\
\hline 15 & $\begin{array}{l}\text { rel } \\
\text { rel } \\
\text { unrel }\end{array}$ & $\begin{array}{l}\text { sheep } \\
\text { lorry } \\
\text { money }\end{array}$ & $\begin{array}{l}\text { cow } \\
\text { train }\end{array}$ & $\begin{array}{l}\text { owca } \\
\text { ciezarowka } \\
\text { pieniadze } \\
\end{array}$ & 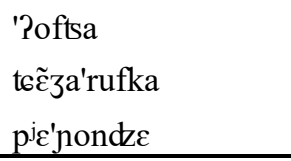 & $\begin{array}{l}\text { krowa } \\
\text { pociag }\end{array}$ & $\begin{array}{l}\text { 'krova } \\
\text { 'potconk }\end{array}$ \\
\hline 16 & $\begin{array}{l}\text { rel } \\
\text { rel } \\
\text { unrel }\end{array}$ & $\begin{array}{l}\text { bee } \\
\text { cup } \\
\text { bubble }\end{array}$ & $\begin{array}{l}\text { flower } \\
\text { milk }\end{array}$ & $\begin{array}{l}\text { pszczola } \\
\text { kubek } \\
\text { banki } \\
\end{array}$ & $\begin{array}{l}\text { 'pftowa } \\
\text { 'kubek } \\
\text { 'bajki }\end{array}$ & $\begin{array}{l}\text { kwiatek } \\
\text { mleko }\end{array}$ & $\begin{array}{l}\text { 'kvjatck } \\
\text { 'mleko }\end{array}$ \\
\hline 17 & $\begin{array}{l}\text { rel } \\
\text { rel } \\
\text { unrel }\end{array}$ & $\begin{array}{l}\text { nappy } \\
\text { picture } \\
\text { giraffe } \\
\end{array}$ & $\begin{array}{l}\text { bib } \\
\text { book }\end{array}$ & $\begin{array}{l}\text { pieluszka } \\
\text { zdjecie } \\
\text { zyrafa } \\
\end{array}$ & $\begin{array}{l}\text { p'e'lufka } \\
\text { 'zdjentec } \\
\text { 3i'rafa }\end{array}$ & $\begin{array}{l}\text { sliniaczek } \\
\text { ksiazka }\end{array}$ & $\begin{array}{l}\text { cli'natfkk } \\
\text { 'k6õsska }\end{array}$ \\
\hline 18 & $\begin{array}{l}\text { rel } \\
\text { rel } \\
\text { unrel }\end{array}$ & $\begin{array}{l}\text { orange } \\
\text { pyjamas } \\
\text { towel }\end{array}$ & $\begin{array}{l}\text { cheese } \\
\text { bed }\end{array}$ & $\begin{array}{l}\text { pomarancz } \\
\text { pizama } \\
\text { recznik } \\
\end{array}$ & $\begin{array}{l}\text { po'maranty } \\
\text { pi'zama } \\
\text { 'rentynik } \\
\end{array}$ & $\begin{array}{l}\text { ser } \\
\text { lozko }\end{array}$ & $\begin{array}{l}\text { scr } \\
\text { 'wufko }\end{array}$ \\
\hline 19 & $\begin{array}{l}\text { rel } \\
\text { rel } \\
\text { unrel }\end{array}$ & $\begin{array}{l}\text { plate } \\
\text { toothbrush } \\
\text { horse } \\
\end{array}$ & $\begin{array}{l}\text { bottle } \\
\text { bath }\end{array}$ & $\begin{array}{l}\text { talerz } \\
\text { szczoteczka do } \\
\text { zebow } \\
\text { kon } \\
\end{array}$ & $\begin{array}{l}\text { 'tale } \\
\text { Jfto'tetgado'zembuf } \\
\text { kon }\end{array}$ & $\begin{array}{l}\text { butelka } \\
\text { wanna }\end{array}$ & $\begin{array}{l}\text { bu'tclka } \\
\text { 'vanna }\end{array}$ \\
\hline 20 & $\begin{array}{l}\text { rel } \\
\text { rel } \\
\text { unrel }\end{array}$ & $\begin{array}{l}\text { toys } \\
\text { water } \\
\text { key }\end{array}$ & $\begin{array}{l}\text { blocks } \\
\text { juice }\end{array}$ & $\begin{array}{l}\text { zabawka } \\
\text { woda } \\
\text { klucz }\end{array}$ & $\begin{array}{l}\text { za'bafka } \\
\text { 'voda } \\
\text { klutf }\end{array}$ & $\begin{array}{l}\text { klocki } \\
\text { sok }\end{array}$ & $\begin{array}{l}\text { 'klotski } \\
\text { sok }\end{array}$ \\
\hline
\end{tabular}

\begin{tabular}{|c|c|c|c|c|c|c|c|}
\hline & & $\begin{array}{l}\text { English } \\
\text { primes }\end{array}$ & targets & $\begin{array}{l}\text { Spanish } \\
\text { primes }\end{array}$ & IPA & targets & IPA \\
\hline 1 & $\begin{array}{l}\text { rel } \\
\text { rel } \\
\text { unrel }\end{array}$ & $\begin{array}{l}\text { table } \\
\text { dog } \\
\text { aeroplane }\end{array}$ & $\begin{array}{l}\text { chair } \\
\text { cat }\end{array}$ & $\begin{array}{l}\text { mesa } \\
\text { perro } \\
\text { avión }\end{array}$ & $\begin{array}{l}\text { 'mesa } \\
\text { 'pero } \\
\text { a'ßjon }\end{array}$ & $\begin{array}{l}\text { silla } \\
\text { gato }\end{array}$ & $\begin{array}{l}\text { 'siKa } \\
\text { 'gato }\end{array}$ \\
\hline 2 & $\begin{array}{l}\text { rel } \\
\text { rel } \\
\text { unrel }\end{array}$ & $\begin{array}{l}\text { arm } \\
\text { spoon } \\
\text { duck }\end{array}$ & $\begin{array}{l}\text { leg } \\
\text { fork }\end{array}$ & $\begin{array}{l}\text { brazo } \\
\text { cuchara } \\
\text { pato }\end{array}$ & $\begin{array}{l}\text { 'braӨo } \\
\text { ku'tfara } \\
\text { 'pato }\end{array}$ & $\begin{array}{l}\text { pierna } \\
\text { tenedor }\end{array}$ & $\begin{array}{l}\text { 'pjerna } \\
\text { tene'ðor }\end{array}$ \\
\hline 3 & rel & sock & shoe & calcetín & 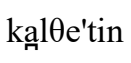 & zapato & $\theta a '$ pato \\
\hline
\end{tabular}




\begin{tabular}{|c|c|c|c|c|c|c|c|}
\hline & $\begin{array}{l}\text { rel } \\
\text { unrel }\end{array}$ & $\begin{array}{l}\text { butter } \\
\text { TV }\end{array}$ & bread & $\begin{array}{l}\text { mantequilla } \\
\text { televisión }\end{array}$ & $\begin{array}{l}\text { mante'kiאa } \\
\text { teleßi'sjon }\end{array}$ & pan & pan \\
\hline 4 & $\begin{array}{l}\text { rel } \\
\text { rel } \\
\text { unrel }\end{array}$ & $\begin{array}{l}\text { toes } \\
\text { moon } \\
\text { house }\end{array}$ & $\begin{array}{l}\text { foot } \\
\text { sun }\end{array}$ & $\begin{array}{l}\text { dedo del pie } \\
\text { luna } \\
\text { casa }\end{array}$ & $\begin{array}{l}\text { 'deðodelpje } \\
\text { 'luna } \\
\text { 'kasa }\end{array}$ & $\begin{array}{l}\text { pie } \\
\text { sol }\end{array}$ & $\begin{array}{l}\text { pje } \\
\text { sol }\end{array}$ \\
\hline 5 & $\begin{array}{l}\text { rel } \\
\text { rel } \\
\text { unrel }\end{array}$ & $\begin{array}{l}\text { tongue } \\
\text { egg } \\
\text { doll }\end{array}$ & $\begin{array}{l}\text { mouth } \\
\text { chicken }\end{array}$ & $\begin{array}{l}\text { lengua } \\
\text { huevo } \\
\text { muñeca }\end{array}$ & $\begin{array}{l}\text { 'lengwa } \\
\text { 'weßo } \\
\text { mu'neka }\end{array}$ & $\begin{array}{l}\text { boca } \\
\text { pollito }\end{array}$ & $\begin{array}{l}\text { 'boka } \\
\text { po'Kito }\end{array}$ \\
\hline 6 & $\begin{array}{l}\text { rel } \\
\text { rel } \\
\text { unrel }\end{array}$ & $\begin{array}{l}\text { hand } \\
\text { tiger } \\
\text { stairs }\end{array}$ & $\begin{array}{l}\text { finger } \\
\text { lion }\end{array}$ & $\begin{array}{l}\text { mano } \\
\text { tigre } \\
\text { escalera }\end{array}$ & $\begin{array}{l}\text { 'mãno } \\
\text { 'tirre } \\
\text { eska'lera }\end{array}$ & $\begin{array}{l}\text { dedo } \\
\text { león }\end{array}$ & $\begin{array}{l}\text { 'deðo } \\
\text { le'on }\end{array}$ \\
\hline 7 & $\begin{array}{l}\text { rel } \\
\text { rel } \\
\text { unrel }\end{array}$ & $\begin{array}{l}\text { glasses } \\
\text { bus } \\
\text { monkey }\end{array}$ & $\begin{array}{l}\text { eyes } \\
\text { car }\end{array}$ & $\begin{array}{l}\text { gafas } \\
\text { autobús } \\
\text { mono }\end{array}$ & $\begin{array}{l}\text { 'gafas } \\
\text { auto'ßus } \\
\text { 'mono }\end{array}$ & $\begin{array}{l}\text { ojos } \\
\text { coche }\end{array}$ & $\begin{array}{l}\text { 'oxos } \\
\text { 'kote }\end{array}$ \\
\hline 8 & $\begin{array}{l}\text { rel } \\
\text { rel } \\
\text { unrel }\end{array}$ & $\begin{array}{l}\text { coat } \\
\text { elephant } \\
\text { bike }\end{array}$ & $\begin{array}{l}\text { hat } \\
\text { mouse }\end{array}$ & $\begin{array}{l}\text { abrigo } \\
\text { elefante } \\
\text { bici }\end{array}$ & 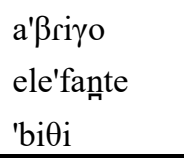 & $\begin{array}{l}\text { sombrero } \\
\text { ratón }\end{array}$ & $\begin{array}{l}\text { som'brero } \\
\text { ra'ton }\end{array}$ \\
\hline 9 & $\begin{array}{l}\text { rel } \\
\text { rel } \\
\text { unrel }\end{array}$ & $\begin{array}{l}\text { ear } \\
\text { window } \\
\text { boat }\end{array}$ & $\begin{array}{l}\text { nose } \\
\text { door }\end{array}$ & $\begin{array}{l}\text { oreja } \\
\text { ventana } \\
\text { barco } \\
\end{array}$ & $\begin{array}{l}\text { o'rexa } \\
\text { ben'tana } \\
\text { 'barko }\end{array}$ & $\begin{array}{l}\text { nariz } \\
\text { puerta }\end{array}$ & $\begin{array}{l}\text { 'nari } \theta \\
\text { 'pwerta }\end{array}$ \\
\hline 10 & $\begin{array}{l}\text { rel } \\
\text { rel } \\
\text { unrel }\end{array}$ & $\begin{array}{l}\text { park } \\
\text { balloon } \\
\text { scissors }\end{array}$ & $\begin{array}{l}\text { tree } \\
\text { ball }\end{array}$ & $\begin{array}{l}\text { parque } \\
\text { globo } \\
\text { tijeras }\end{array}$ & $\begin{array}{l}\text { 'parke } \\
\text { 'gloßo } \\
\text { ti'xeras }\end{array}$ & $\begin{array}{l}\text { árbol } \\
\text { pelota }\end{array}$ & $\begin{array}{l}\text { 'arßol } \\
\text { pe'lota }\end{array}$ \\
\hline 11 & $\begin{array}{l}\text { rel } \\
\text { rel } \\
\text { unrel }\end{array}$ & $\begin{array}{l}\text { swing } \\
\text { cereal } \\
\text { penguin }\end{array}$ & $\begin{array}{l}\text { slide } \\
\text { bowl }\end{array}$ & $\begin{array}{l}\text { columpio } \\
\text { cereales } \\
\text { pingüino }\end{array}$ & $\begin{array}{l}\text { ko'lumpjo } \\
\theta \text { ere'ales } \\
\text { pin' } \gamma \text { wino }\end{array}$ & $\begin{array}{l}\text { tobogán } \\
\text { bol }\end{array}$ & $\begin{array}{l}\text { toßo'yan } \\
\text { bol }\end{array}$ \\
\hline 12 & $\begin{array}{l}\text { rel } \\
\text { rel } \\
\text { unrel }\end{array}$ & $\begin{array}{l}\text { apple } \\
\text { fish } \\
\text { potty }\end{array}$ & $\begin{array}{l}\text { banana } \\
\text { frog }\end{array}$ & $\begin{array}{l}\text { manzana } \\
\text { pez } \\
\text { orinal }\end{array}$ & $\begin{array}{l}\text { man' } \theta \text { ana } \\
\text { pe } \theta \\
\text { ori'nal }\end{array}$ & $\begin{array}{l}\text { plátano } \\
\text { rana }\end{array}$ & $\begin{array}{l}\text { 'platano } \\
\text { 'rana }\end{array}$ \\
\hline 13 & $\begin{array}{l}\text { rel } \\
\text { rel } \\
\text { unrel }\end{array}$ & $\begin{array}{l}\text { cake } \\
\text { sky } \\
\text { pillow }\end{array}$ & $\begin{array}{l}\text { biscuit } \\
\text { bird }\end{array}$ & $\begin{array}{l}\text { bizcocho } \\
\text { cielo } \\
\text { almohada }\end{array}$ & 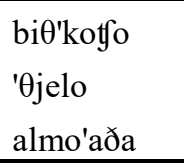 & $\begin{array}{l}\text { galleta } \\
\text { pájaro }\end{array}$ & $\begin{array}{l}\text { ga'Keta } \\
\text { 'paxaro }\end{array}$ \\
\hline 14 & $\begin{array}{l}\text { rel } \\
\text { rel } \\
\text { unrel }\end{array}$ & $\begin{array}{l}\text { carrot } \\
\text { button } \\
\text { soap } \\
\end{array}$ & $\begin{array}{l}\text { peas } \\
\text { trousers }\end{array}$ & $\begin{array}{l}\text { zanahoria } \\
\text { botón } \\
\text { jabón }\end{array}$ & $\begin{array}{l}\text { Oana'orja } \\
\text { bo'ton } \\
\text { xa'ßon }\end{array}$ & $\begin{array}{l}\text { guisantes } \\
\text { pantalón }\end{array}$ & $\begin{array}{l}\text { gi'sañtes } \\
\text { panta'lon }\end{array}$ \\
\hline 15 & $\begin{array}{l}\text { rel } \\
\text { rel } \\
\text { unrel }\end{array}$ & $\begin{array}{l}\text { sheep } \\
\text { lorry } \\
\text { money }\end{array}$ & $\begin{array}{l}\text { cow } \\
\text { train }\end{array}$ & $\begin{array}{l}\text { oveja } \\
\text { camión } \\
\text { monedas }\end{array}$ & $\begin{array}{l}\text { o'ßexa } \\
\text { ka'mjon } \\
\text { mo'neðas }\end{array}$ & $\begin{array}{l}\text { vaca } \\
\text { tren }\end{array}$ & $\begin{array}{l}\text { 'baka } \\
\text { tren }\end{array}$ \\
\hline 16 & $\begin{array}{l}\text { rel } \\
\text { rel } \\
\text { unrel }\end{array}$ & $\begin{array}{l}\text { bee } \\
\text { cup } \\
\text { bubble }\end{array}$ & $\begin{array}{l}\text { flower } \\
\text { milk }\end{array}$ & $\begin{array}{l}\text { abeja } \\
\text { taza } \\
\text { burbuja }\end{array}$ & $\begin{array}{l}\text { a'ßexa } \\
\text { 'ta } \theta a \\
\text { bur' } \beta u x a \\
\end{array}$ & $\begin{array}{l}\text { flor } \\
\text { leche }\end{array}$ & $\begin{array}{l}\text { flor } \\
\text { 'lete }\end{array}$ \\
\hline 17 & $\begin{array}{l}\text { rel } \\
\text { rel } \\
\text { unrel }\end{array}$ & $\begin{array}{l}\text { nappy } \\
\text { picture } \\
\text { giraffe }\end{array}$ & $\begin{array}{l}\text { bib } \\
\text { book }\end{array}$ & $\begin{array}{l}\text { pañal } \\
\text { foto } \\
\text { jirafa }\end{array}$ & $\begin{array}{l}\text { pa'jal } \\
\text { 'foto } \\
\text { xi'rafa }\end{array}$ & $\begin{array}{l}\text { babero } \\
\text { libro }\end{array}$ & $\begin{array}{l}\text { ba'ßero } \\
\text { 'libro }\end{array}$ \\
\hline
\end{tabular}




\begin{tabular}{|c|c|c|c|c|c|c|c|}
\hline 18 & $\begin{array}{l}\text { rel } \\
\text { rel } \\
\text { unrel }\end{array}$ & $\begin{array}{l}\text { orange } \\
\text { pyjamas } \\
\text { towel }\end{array}$ & $\begin{array}{l}\text { cheese } \\
\text { bed }\end{array}$ & $\begin{array}{l}\text { naranja } \\
\text { pijama } \\
\text { toalla }\end{array}$ & $\begin{array}{l}\text { na'ranxa } \\
\text { pi'xama } \\
\text { to'aKa }\end{array}$ & $\begin{array}{l}\text { queso } \\
\text { cama }\end{array}$ & $\begin{array}{l}\text { 'keso } \\
\text { 'kama }\end{array}$ \\
\hline 19 & $\begin{array}{l}\text { rel } \\
\text { rel } \\
\text { unrel }\end{array}$ & $\begin{array}{l}\text { plate } \\
\text { toothbrush } \\
\text { horse } \\
\end{array}$ & $\begin{array}{l}\text { bottle } \\
\text { bath }\end{array}$ & $\begin{array}{l}\text { plato } \\
\text { cepillo de dientes } \\
\text { caballo }\end{array}$ & $\begin{array}{l}\text { 'plato } \\
\text { Өe'piאoðe'ðjentes } \\
\text { ka'ßaКo }\end{array}$ & $\begin{array}{l}\text { botella } \\
\text { bañera }\end{array}$ & $\begin{array}{l}\text { bo'te } \kappa a \\
\text { ba'nera }\end{array}$ \\
\hline 20 & $\begin{array}{l}\text { rel } \\
\text { rel } \\
\text { unrel }\end{array}$ & $\begin{array}{l}\text { toys } \\
\text { water } \\
\text { key }\end{array}$ & $\begin{array}{l}\text { blocks } \\
\text { juice }\end{array}$ & $\begin{array}{l}\text { juguetes } \\
\text { agua } \\
\text { llave }\end{array}$ & 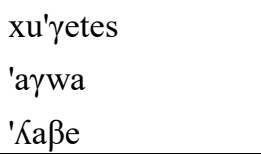 & $\begin{array}{l}\text { cubo } \\
\text { zumo }\end{array}$ & $\begin{array}{l}\text { 'kußo } \\
\text { 'Oumo }\end{array}$ \\
\hline
\end{tabular}

\begin{tabular}{|c|c|c|c|c|c|c|c|}
\hline & & $\begin{array}{l}\text { English } \\
\text { primes }\end{array}$ & targets & $\begin{array}{l}\text { German } \\
\text { primes }\end{array}$ & IPA & targets & IPA \\
\hline 1 & $\begin{array}{l}\text { rel } \\
\text { rel } \\
\text { unrel }\end{array}$ & $\begin{array}{l}\text { table } \\
\text { dog } \\
\text { aeroplane }\end{array}$ & $\begin{array}{l}\text { chair } \\
\text { cat }\end{array}$ & $\begin{array}{l}\text { Tisch } \\
\text { Hund } \\
\text { Flugzeug }\end{array}$ & $\begin{array}{l}\operatorname{tr} \int \\
\text { hont } \\
\text { 'flu:ktsork }\end{array}$ & $\begin{array}{l}\text { Stuhl } \\
\text { Katze }\end{array}$ & $\begin{array}{l}\text { ftu:1 } \\
\text { 'katsə }\end{array}$ \\
\hline 2 & $\begin{array}{l}\text { rel } \\
\text { rel } \\
\text { unrel }\end{array}$ & $\begin{array}{l}\text { arm } \\
\text { spoon } \\
\text { duck }\end{array}$ & $\begin{array}{l}\text { leg } \\
\text { fork }\end{array}$ & $\begin{array}{l}\text { Arm } \\
\text { Löffel } \\
\text { Ente } \\
\end{array}$ & $\begin{array}{l}\text { arm } \\
\text { 'lœfəl } \\
\text { 'Entə } \\
\end{array}$ & $\begin{array}{l}\text { Bein } \\
\text { Gabel }\end{array}$ & $\begin{array}{l}\text { bain } \\
\text { 'ga:bəl }\end{array}$ \\
\hline 3 & $\begin{array}{l}\text { rel } \\
\text { rel } \\
\text { unrel }\end{array}$ & $\begin{array}{l}\text { sock } \\
\text { butter } \\
\text { TV } \\
\end{array}$ & $\begin{array}{l}\text { shoe } \\
\text { bread }\end{array}$ & $\begin{array}{l}\text { Socke } \\
\text { Butter } \\
\text { Fernseher }\end{array}$ & $\begin{array}{l}\text { 'zokə } \\
\text { 'butər } \\
\text { 'fernze:ər }\end{array}$ & $\begin{array}{l}\text { Schuh } \\
\text { Brot }\end{array}$ & $\begin{array}{l}\text { Ju: } \\
\text { bro:t }\end{array}$ \\
\hline 4 & $\begin{array}{l}\text { rel } \\
\text { rel } \\
\text { unrel }\end{array}$ & $\begin{array}{l}\text { toes } \\
\text { moon } \\
\text { house }\end{array}$ & $\begin{array}{l}\text { foot } \\
\text { sun }\end{array}$ & $\begin{array}{l}\text { Zeh } \\
\text { Mond } \\
\text { Haus } \\
\end{array}$ & $\begin{array}{l}\text { tse: } \\
\text { mo:nt } \\
\text { haus } \\
\end{array}$ & $\begin{array}{l}\text { Fuß } \\
\text { Sonne }\end{array}$ & $\begin{array}{l}\text { fu:s } \\
\text { 'zonə }\end{array}$ \\
\hline 5 & $\begin{array}{l}\text { rel } \\
\text { rel } \\
\text { unrel }\end{array}$ & $\begin{array}{l}\text { tongue } \\
\text { egg } \\
\text { doll }\end{array}$ & $\begin{array}{l}\text { mouth } \\
\text { chicken }\end{array}$ & $\begin{array}{l}\text { Zunge } \\
\text { Eier } \\
\text { Puppe }\end{array}$ & $\begin{array}{l}\text { 'tsonə } \\
\text { aiər } \\
\text { 'popə }\end{array}$ & $\begin{array}{l}\text { Mund } \\
\text { Huhn }\end{array}$ & $\begin{array}{l}\text { mont } \\
\text { hu:n }\end{array}$ \\
\hline 6 & $\begin{array}{l}\text { rel } \\
\text { rel } \\
\text { unrel }\end{array}$ & $\begin{array}{l}\text { hand } \\
\text { tiger } \\
\text { stairs }\end{array}$ & $\begin{array}{l}\text { finger } \\
\text { lion }\end{array}$ & $\begin{array}{l}\text { Hand } \\
\text { Tiger } \\
\text { Treppe }\end{array}$ & $\begin{array}{l}\text { hant } \\
\text { 'ti:gər } \\
\text { 'trepə }\end{array}$ & $\begin{array}{l}\text { Finger } \\
\text { Löwe }\end{array}$ & $\begin{array}{l}\text { 'finər } \\
\text { 'lø:və }\end{array}$ \\
\hline 7 & $\begin{array}{l}\text { rel } \\
\text { rel } \\
\text { unrel } \\
\end{array}$ & $\begin{array}{l}\text { glasses } \\
\text { bus } \\
\text { monkey }\end{array}$ & $\begin{array}{l}\text { eyes } \\
\text { car }\end{array}$ & $\begin{array}{l}\text { Brille } \\
\text { Bus } \\
\text { Affe } \\
\end{array}$ & $\begin{array}{l}\text { 'brilə } \\
\text { bus } \\
\text { afə }\end{array}$ & $\begin{array}{l}\text { Auge } \\
\text { Auto }\end{array}$ & $\begin{array}{l}\text { 'augə } \\
\text { 'auto: }\end{array}$ \\
\hline 8 & $\begin{array}{l}\text { rel } \\
\text { rel } \\
\text { unrel }\end{array}$ & $\begin{array}{l}\text { coat } \\
\text { elephant } \\
\text { bike }\end{array}$ & $\begin{array}{l}\text { hat } \\
\text { mouse }\end{array}$ & $\begin{array}{l}\text { Mantel } \\
\text { Elefant } \\
\text { Fahrrad }\end{array}$ & $\begin{array}{l}\text { 'mantəl } \\
\text { ele' fant } \\
\text { 'fa:rra:t }\end{array}$ & $\begin{array}{l}\text { Mütze } \\
\text { Maus }\end{array}$ & $\begin{array}{l}\text { 'mytsə } \\
\text { maus }\end{array}$ \\
\hline 9 & $\begin{array}{l}\text { rel } \\
\text { rel } \\
\text { unrel }\end{array}$ & $\begin{array}{l}\text { ear } \\
\text { window } \\
\text { boat }\end{array}$ & $\begin{array}{l}\text { nose } \\
\text { door }\end{array}$ & $\begin{array}{l}\text { Ohr } \\
\text { Fenster } \\
\text { Schiff }\end{array}$ & $\begin{array}{l}\text { o:r } \\
\text { 'fenstər } \\
\text { Jif }\end{array}$ & $\begin{array}{l}\text { Nase } \\
\text { Tür }\end{array}$ & $\begin{array}{l}\text { 'na:zə } \\
\text { ty:r }\end{array}$ \\
\hline 10 & rel & park & tree & Park & park & Baum & baum \\
\hline
\end{tabular}




\begin{tabular}{|c|c|c|c|c|c|c|c|}
\hline & $\begin{array}{l}\text { rel } \\
\text { unrel }\end{array}$ & $\begin{array}{l}\text { balloon } \\
\text { scissors }\end{array}$ & ball & $\begin{array}{l}\text { Luftballon } \\
\text { Schere }\end{array}$ & $\begin{array}{l}\text { 'loftbalon } \\
\text { 'Se:rə }\end{array}$ & Ball & bal \\
\hline 11 & $\begin{array}{l}\text { rel } \\
\text { rel } \\
\text { unrel }\end{array}$ & $\begin{array}{l}\text { swing } \\
\text { cereal } \\
\text { penguin }\end{array}$ & $\begin{array}{l}\text { slide } \\
\text { bowl }\end{array}$ & $\begin{array}{l}\text { Schaukel } \\
\text { Müsli } \\
\text { Pinguin } \\
\end{array}$ & $\begin{array}{l}\text { 'Jaukəl } \\
\text { 'my:sli: } \\
\text { 'pingwin }\end{array}$ & $\begin{array}{l}\text { Rutsche } \\
\text { Schüssel }\end{array}$ & $\begin{array}{l}\text { 'rotfo } \\
\text { 'Jysəl }\end{array}$ \\
\hline 12 & $\begin{array}{l}\text { rel } \\
\text { rel } \\
\text { unrel }\end{array}$ & $\begin{array}{l}\text { apple } \\
\text { fish } \\
\text { potty }\end{array}$ & $\begin{array}{l}\text { banana } \\
\text { frog }\end{array}$ & $\begin{array}{l}\text { Apfel } \\
\text { Fisch } \\
\text { Töpfchen }\end{array}$ & $\begin{array}{l}\text { 'apfəl } \\
\text { fIJ } \\
\text { 'tœpfçən }\end{array}$ & $\begin{array}{l}\text { Banane } \\
\text { Frosch }\end{array}$ & $\begin{array}{l}\text { ba'na:nə } \\
\text { fros }\end{array}$ \\
\hline 13 & $\begin{array}{l}\text { rel } \\
\text { rel } \\
\text { unrel }\end{array}$ & $\begin{array}{l}\text { cake } \\
\text { sky } \\
\text { pillow }\end{array}$ & $\begin{array}{l}\text { biscuit } \\
\text { bird }\end{array}$ & $\begin{array}{l}\text { Kuchen } \\
\text { Himmel } \\
\text { Kissen } \\
\end{array}$ & $\begin{array}{l}\text { 'kuxən } \\
\text { 'hıməl } \\
\text { 'kisən } \\
\end{array}$ & $\begin{array}{l}\text { Keks } \\
\text { Vogel }\end{array}$ & $\begin{array}{l}\text { ke:ks } \\
\text { 'fo:gəl }\end{array}$ \\
\hline 14 & $\begin{array}{l}\text { rel } \\
\text { rel } \\
\text { unrel }\end{array}$ & $\begin{array}{l}\text { carrot } \\
\text { button } \\
\text { soap }\end{array}$ & $\begin{array}{l}\text { peas } \\
\text { trousers }\end{array}$ & $\begin{array}{l}\text { Möhre } \\
\text { Knopf } \\
\text { Seife } \\
\end{array}$ & $\begin{array}{l}\text { 'mø:rə } \\
\text { knəpf } \\
\text { 'zaifə } \\
\end{array}$ & $\begin{array}{l}\text { Erbse } \\
\text { Hose }\end{array}$ & $\begin{array}{l}\text { 'crpsə } \\
\text { 'ho:zə }\end{array}$ \\
\hline 15 & $\begin{array}{l}\text { rel } \\
\text { rel } \\
\text { unrel }\end{array}$ & $\begin{array}{l}\text { sheep } \\
\text { lorry } \\
\text { money }\end{array}$ & $\begin{array}{l}\text { cow } \\
\text { train }\end{array}$ & $\begin{array}{l}\text { Schaf } \\
\text { Lastwagen } \\
\text { Geld }\end{array}$ & $\begin{array}{l}\text { Ja:f } \\
\text { 'lastva:gən } \\
\text { gelt }\end{array}$ & $\begin{array}{l}\text { Kuh } \\
\text { Bahn }\end{array}$ & $\begin{array}{l}\text { ku: } \\
\text { ba:n }\end{array}$ \\
\hline 16 & $\begin{array}{l}\text { rel } \\
\text { rel } \\
\text { unrel }\end{array}$ & $\begin{array}{l}\text { bee } \\
\text { cup } \\
\text { bubble }\end{array}$ & $\begin{array}{l}\text { flower } \\
\text { milk }\end{array}$ & $\begin{array}{l}\text { Biene } \\
\text { Tasse } \\
\text { Seifenblase }\end{array}$ & $\begin{array}{l}\text { 'bi:nə } \\
\text { 'tasə } \\
\text { 'zaifənbla:zə }\end{array}$ & $\begin{array}{l}\text { Blume } \\
\text { Milch }\end{array}$ & $\begin{array}{l}\text { 'blu:mə } \\
\text { mılç }\end{array}$ \\
\hline 17 & $\begin{array}{l}\text { rel } \\
\text { rel } \\
\text { unrel }\end{array}$ & $\begin{array}{l}\text { nappy } \\
\text { picture } \\
\text { giraffe }\end{array}$ & $\begin{array}{l}\text { bib } \\
\text { book }\end{array}$ & $\begin{array}{l}\text { Windel } \\
\text { Bild } \\
\text { Giraffe }\end{array}$ & $\begin{array}{l}\text { 'vindəl } \\
\text { bilt } \\
\text { gI'ra:fə }\end{array}$ & $\begin{array}{l}\text { Latzchen } \\
\text { Buch }\end{array}$ & $\begin{array}{l}\text { 'letsçən } \\
\text { bu:x }\end{array}$ \\
\hline 18 & $\begin{array}{l}\text { rel } \\
\text { rel } \\
\text { unrel }\end{array}$ & $\begin{array}{l}\text { orange } \\
\text { pyjamas } \\
\text { towel }\end{array}$ & $\begin{array}{l}\text { cheese } \\
\text { bed }\end{array}$ & $\begin{array}{l}\text { Orange } \\
\text { Schlafanzug } \\
\text { Handtuch }\end{array}$ & $\begin{array}{l}\text { apfəl'zi:nə } \\
\text { 'fla:fantsu:k } \\
\text { 'hanttu:x } \\
\end{array}$ & $\begin{array}{l}\text { Kase } \\
\text { Bett }\end{array}$ & $\begin{array}{l}\text { 'ke:zə } \\
\text { bet }\end{array}$ \\
\hline 19 & $\begin{array}{l}\text { rel } \\
\text { rel } \\
\text { unrel }\end{array}$ & $\begin{array}{l}\text { plate } \\
\text { toothbrush } \\
\text { horse } \\
\end{array}$ & $\begin{array}{l}\text { bottle } \\
\text { bath }\end{array}$ & $\begin{array}{l}\text { Teller } \\
\text { Zahnbürste } \\
\text { Pferd }\end{array}$ & $\begin{array}{l}\text { 'tclər } \\
\text { 'tsa:nbyrstə } \\
\text { pfe:rt }\end{array}$ & $\begin{array}{l}\text { Flasche } \\
\text { Badewanne }\end{array}$ & $\begin{array}{l}\text { 'flajə } \\
\text { 'ba:dəvanə }\end{array}$ \\
\hline 20 & $\begin{array}{l}\text { rel } \\
\text { rel } \\
\text { unrel }\end{array}$ & $\begin{array}{l}\text { toys } \\
\text { water } \\
\text { key }\end{array}$ & $\begin{array}{l}\text { blocks } \\
\text { juice }\end{array}$ & $\begin{array}{l}\text { Spielzeug } \\
\text { Wasser } \\
\text { Schlüssel }\end{array}$ & $\begin{array}{l}\text { 'Jpi:ltsərk } \\
\text { 'vasər } \\
\text { 'flysəl }\end{array}$ & $\begin{array}{l}\text { Klotz } \\
\text { Saft }\end{array}$ & $\begin{array}{l}\text { klots } \\
\text { zaft }\end{array}$ \\
\hline
\end{tabular}

\begin{tabular}{|ll|ll|llll|}
\cline { 3 - 8 } \multicolumn{1}{c|}{} & \multicolumn{2}{|l|}{$\begin{array}{l}\text { English } \\
\text { primes }\end{array}$} & targets & $\begin{array}{l}\text { Dutch } \\
\text { primes }\end{array}$ & IPA & targets & IPA \\
\hline \multirow{2}{*}{1} & rel & table & chair & tafel & 'ta:fəl & stoel & stul \\
& rel & dog & cat & hond & hont & pus \\
& unrel & aeroplane & & vliegtuig & 'vliytœyy & been & ben \\
\hline 2 & rel & arm & leg & arm & arm & vork & vork
\end{tabular}




\begin{tabular}{|c|c|c|c|c|c|c|c|}
\hline & unrel & duck & & eend & ent & & \\
\hline 3 & $\begin{array}{l}\text { rel } \\
\text { rel } \\
\text { unrel }\end{array}$ & $\begin{array}{l}\text { sock } \\
\text { butter } \\
\text { TV } \\
\end{array}$ & $\begin{array}{l}\text { shoe } \\
\text { bread }\end{array}$ & $\begin{array}{l}\text { sok } \\
\text { boter } \\
\text { televisie }\end{array}$ & $\begin{array}{l}\text { sok } \\
\text { 'botər } \\
\text { 'teləvizi }\end{array}$ & $\begin{array}{l}\text { schoen } \\
\text { brood }\end{array}$ & $\begin{array}{l}\text { syun } \\
\text { brot }\end{array}$ \\
\hline 4 & $\begin{array}{l}\text { rel } \\
\text { rel } \\
\text { unrel }\end{array}$ & $\begin{array}{l}\text { toes } \\
\text { moon } \\
\text { house }\end{array}$ & $\begin{array}{l}\text { foot } \\
\text { sun }\end{array}$ & $\begin{array}{l}\text { teen } \\
\text { maan } \\
\text { huis }\end{array}$ & $\begin{array}{l}\text { ten } \\
\text { ma:n } \\
\text { hœys }\end{array}$ & $\begin{array}{l}\text { voet } \\
\text { zon }\end{array}$ & $\begin{array}{l}\text { vut } \\
\text { zon }\end{array}$ \\
\hline 5 & $\begin{array}{l}\text { rel } \\
\text { rel } \\
\text { unrel }\end{array}$ & $\begin{array}{l}\text { tongue } \\
\text { egg } \\
\text { doll }\end{array}$ & $\begin{array}{l}\text { mouth } \\
\text { chicken }\end{array}$ & $\begin{array}{l}\text { tong } \\
\text { ei } \\
\text { pop }\end{array}$ & $\begin{array}{l}\text { ton } \\
\varepsilon \dot{i} \\
\text { pop }\end{array}$ & $\begin{array}{l}\text { mond } \\
\text { kuiken }\end{array}$ & $\begin{array}{l}\text { mont } \\
\text { 'kœykə }\end{array}$ \\
\hline 6 & $\begin{array}{l}\text { rel } \\
\text { rel } \\
\text { unrel }\end{array}$ & $\begin{array}{l}\text { hand } \\
\text { tiger } \\
\text { stairs }\end{array}$ & $\begin{array}{l}\text { finger } \\
\text { lion }\end{array}$ & $\begin{array}{l}\text { hand } \\
\text { tijger } \\
\text { trap }\end{array}$ & $\begin{array}{l}\text { hant } \\
\text { 'tciyor } \\
\text { trap }\end{array}$ & $\begin{array}{l}\text { vinger } \\
\text { leeuw }\end{array}$ & $\begin{array}{l}\text { 'vinər } \\
\text { lev }\end{array}$ \\
\hline 7 & $\begin{array}{l}\text { rel } \\
\text { rel } \\
\text { unrel }\end{array}$ & $\begin{array}{l}\text { glasses } \\
\text { bus } \\
\text { monkey }\end{array}$ & $\begin{array}{l}\text { eyes } \\
\text { car }\end{array}$ & $\begin{array}{l}\text { bril } \\
\text { bus } \\
\text { aap }\end{array}$ & $\begin{array}{l}\text { bril } \\
\text { bys } \\
\text { a:p }\end{array}$ & $\begin{array}{l}\text { oog } \\
\text { auto }\end{array}$ & $\begin{array}{l}\text { of } \\
\text { 'auto }\end{array}$ \\
\hline 8 & $\begin{array}{l}\text { rel } \\
\text { rel } \\
\text { unrel }\end{array}$ & $\begin{array}{l}\text { coat } \\
\text { elephant } \\
\text { bike }\end{array}$ & $\begin{array}{l}\text { hat } \\
\text { mouse }\end{array}$ & $\begin{array}{l}\text { jas } \\
\text { olifant } \\
\text { fiets }\end{array}$ & $\begin{array}{l}\text { jas } \\
\text { 'olifant } \\
\text { fits }\end{array}$ & $\begin{array}{l}\text { hoed } \\
\text { muis }\end{array}$ & $\begin{array}{l}\text { hut } \\
\text { mœys }\end{array}$ \\
\hline 9 & $\begin{array}{l}\text { rel } \\
\text { rel } \\
\text { unrel }\end{array}$ & $\begin{array}{l}\text { ear } \\
\text { window } \\
\text { boat }\end{array}$ & $\begin{array}{l}\text { nose } \\
\text { door }\end{array}$ & $\begin{array}{l}\text { oor } \\
\text { raam } \\
\text { boot }\end{array}$ & $\begin{array}{l}\text { or } \\
\text { ra:m } \\
\text { bot }\end{array}$ & $\begin{array}{l}\text { neus } \\
\text { deur }\end{array}$ & $\begin{array}{l}\text { nø:s } \\
\text { dø:r }\end{array}$ \\
\hline 10 & $\begin{array}{l}\text { rel } \\
\text { rel } \\
\text { unrel }\end{array}$ & $\begin{array}{l}\text { park } \\
\text { balloon } \\
\text { scissors }\end{array}$ & $\begin{array}{l}\text { tree } \\
\text { ball }\end{array}$ & $\begin{array}{l}\text { park } \\
\text { ballon } \\
\text { schaar }\end{array}$ & $\begin{array}{l}\text { park } \\
\text { 'balon } \\
\text { sya:r }\end{array}$ & $\begin{array}{l}\text { boom } \\
\text { bal }\end{array}$ & $\begin{array}{l}\text { bom } \\
\text { bal }\end{array}$ \\
\hline 11 & $\begin{array}{l}\text { rel } \\
\text { rel } \\
\text { unrel }\end{array}$ & $\begin{array}{l}\text { swing } \\
\text { cereal } \\
\text { penguin }\end{array}$ & $\begin{array}{l}\text { slide } \\
\text { bowl }\end{array}$ & $\begin{array}{l}\text { schommel } \\
\text { cornflakes } \\
\text { pinguïn } \\
\end{array}$ & $\begin{array}{l}\text { 'syoməl } \\
\text { 'kornfleks } \\
\text { 'pıngoin }\end{array}$ & $\begin{array}{l}\text { glijbaan } \\
\text { kom }\end{array}$ & $\begin{array}{l}\text { 'yleiba:n } \\
\text { kom }\end{array}$ \\
\hline 12 & $\begin{array}{l}\text { rel } \\
\text { rel } \\
\text { unrel }\end{array}$ & $\begin{array}{l}\text { apple } \\
\text { fish } \\
\text { potty }\end{array}$ & $\begin{array}{l}\text { banana } \\
\text { frog }\end{array}$ & $\begin{array}{l}\text { appel } \\
\text { vis } \\
\text { potje } \\
\end{array}$ & $\begin{array}{l}\text { 'apəl } \\
\text { VIS } \\
\text { 'potjə }\end{array}$ & $\begin{array}{l}\text { banaan } \\
\text { kikker }\end{array}$ & $\begin{array}{l}\text { 'ba:na:n } \\
\text { 'kıkər }\end{array}$ \\
\hline 13 & $\begin{array}{l}\text { rel } \\
\text { rel } \\
\text { unrel }\end{array}$ & $\begin{array}{l}\text { cake } \\
\text { sky } \\
\text { pillow }\end{array}$ & $\begin{array}{l}\text { biscuit } \\
\text { bird }\end{array}$ & $\begin{array}{l}\text { cake } \\
\text { lucht } \\
\text { hoofdkussen }\end{array}$ & $\begin{array}{l}\text { kek } \\
\text { lyyt } \\
\text { 'hoftkyso }\end{array}$ & $\begin{array}{l}\text { beschuit } \\
\text { vogel }\end{array}$ & $\begin{array}{l}\text { bə'syœyt } \\
\text { 'voyəl }\end{array}$ \\
\hline 14 & $\begin{array}{l}\text { rel } \\
\text { rel } \\
\text { unrel }\end{array}$ & $\begin{array}{l}\text { carrot } \\
\text { button } \\
\text { soap } \\
\end{array}$ & $\begin{array}{l}\text { peas } \\
\text { trousers }\end{array}$ & $\begin{array}{l}\text { wortel } \\
\text { knoop } \\
\text { zeep }\end{array}$ & $\begin{array}{l}\text { 'vortəl } \\
\text { knop } \\
\text { zep }\end{array}$ & $\begin{array}{l}\text { erwtjes } \\
\text { langebroek }\end{array}$ & $\begin{array}{l}\text { 'ertjəs } \\
\text { 'layəbruk }\end{array}$ \\
\hline 15 & $\begin{array}{l}\text { rel } \\
\text { rel } \\
\text { unrel }\end{array}$ & $\begin{array}{l}\text { sheep } \\
\text { lorry } \\
\text { money }\end{array}$ & $\begin{array}{l}\text { cow } \\
\text { train }\end{array}$ & $\begin{array}{l}\text { schaap } \\
\text { vrachtwagen } \\
\text { geld }\end{array}$ & $\begin{array}{l}\text { sya:p } \\
\text { 'vraytoa:yə } \\
\text { yelt }\end{array}$ & $\begin{array}{l}\text { koe } \\
\text { trein }\end{array}$ & $\begin{array}{l}\mathrm{ku} \\
\text { trein }\end{array}$ \\
\hline 16 & $\begin{array}{l}\text { rel } \\
\text { rel } \\
\text { unrel }\end{array}$ & $\begin{array}{l}\text { bee } \\
\text { cup } \\
\text { bubble }\end{array}$ & $\begin{array}{l}\text { flower } \\
\text { milk }\end{array}$ & $\begin{array}{l}\text { bij } \\
\text { beker } \\
\text { bubbels }\end{array}$ & $\begin{array}{l}\text { bei } \\
\text { 'bekər } \\
\text { 'bybəls }\end{array}$ & $\begin{array}{l}\text { bloem } \\
\text { melk }\end{array}$ & $\begin{array}{l}\text { blum } \\
\text { melk }\end{array}$ \\
\hline 17 & rel & nappy & bib & luier & 'lœyjər & slabbetje & 'slabətjə \\
\hline
\end{tabular}




\begin{tabular}{|c|c|c|c|c|c|c|c|}
\hline & $\begin{array}{l}\text { rel } \\
\text { unrel }\end{array}$ & $\begin{array}{l}\text { picture } \\
\text { giraffe }\end{array}$ & book & $\begin{array}{l}\text { foto } \\
\text { giraf }\end{array}$ & $\begin{array}{l}\text { 'foto } \\
\text { 'zjiraf }\end{array}$ & boek & buk \\
\hline 18 & $\begin{array}{l}\text { rel } \\
\text { rel } \\
\text { unrel }\end{array}$ & $\begin{array}{l}\text { orange } \\
\text { pyjamas } \\
\text { towel }\end{array}$ & $\begin{array}{l}\text { cheese } \\
\text { bed }\end{array}$ & $\begin{array}{l}\text { appelsien } \\
\text { pyjama } \\
\text { handdoek }\end{array}$ & $\begin{array}{l}\text { 'apəlsin } \\
\text { 'pija:ma: } \\
\text { 'handuk }\end{array}$ & $\begin{array}{l}\text { kaas } \\
\text { bed }\end{array}$ & $\begin{array}{l}\mathrm{ka}: \mathrm{s} \\
\mathrm{bct}\end{array}$ \\
\hline 19 & $\begin{array}{l}\text { rel } \\
\text { rel } \\
\text { unrel }\end{array}$ & $\begin{array}{l}\text { plate } \\
\text { toothbrush } \\
\text { horse }\end{array}$ & $\begin{array}{l}\text { bottle } \\
\text { bath }\end{array}$ & $\begin{array}{l}\text { bord } \\
\text { tandenborstel } \\
\text { paard }\end{array}$ & $\begin{array}{l}\text { bort } \\
\text { 'tandəbərstəl } \\
\text { pa:rt }\end{array}$ & $\begin{array}{l}\text { fles } \\
\text { bad }\end{array}$ & $\begin{array}{l}\text { fles } \\
\text { bat }\end{array}$ \\
\hline 20 & $\begin{array}{l}\text { rel } \\
\text { rel } \\
\text { unrel }\end{array}$ & $\begin{array}{l}\text { toys } \\
\text { water } \\
\text { key }\end{array}$ & $\begin{array}{l}\text { blocks } \\
\text { juice }\end{array}$ & $\begin{array}{l}\text { speelgoed } \\
\text { water } \\
\text { sleutel }\end{array}$ & $\begin{array}{l}\text { 'spelyut } \\
\text { 'va:tər } \\
\text { 'slø:təl }\end{array}$ & $\begin{array}{l}\text { blokken } \\
\text { sap }\end{array}$ & $\begin{array}{l}\text { 'blokə } \\
\text { sap }\end{array}$ \\
\hline
\end{tabular}

\begin{tabular}{|c|c|c|c|c|c|c|c|}
\hline & & $\begin{array}{l}\text { English } \\
\text { primes }\end{array}$ & targets & $\begin{array}{l}\text { Greek } \\
\text { primes }\end{array}$ & IPA & targets & IPA \\
\hline 1 & $\begin{array}{l}\text { rel } \\
\text { rel } \\
\text { unrel }\end{array}$ & $\begin{array}{l}\text { table } \\
\text { dog } \\
\text { aeroplane }\end{array}$ & $\begin{array}{l}\text { chair } \\
\text { cat }\end{array}$ & 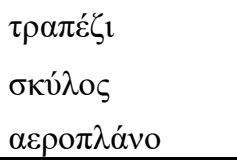 & $\begin{array}{l}\text { tra'pezi } \\
\text { 'skilos } \\
\text { aero'plano }\end{array}$ & $\begin{array}{l}\kappa \alpha \rho \varepsilon ́ \kappa \lambda \alpha \\
\gamma \alpha \dot{\alpha} \alpha \alpha\end{array}$ & $\begin{array}{l}\text { ka'rekla } \\
\text { 'yata }\end{array}$ \\
\hline 2 & $\begin{array}{l}\text { rel } \\
\text { rel } \\
\text { unrel }\end{array}$ & $\begin{array}{l}\text { arm } \\
\text { spoon } \\
\text { duck }\end{array}$ & $\begin{array}{l}\text { leg } \\
\text { fork }\end{array}$ & $\begin{array}{l}\mu \pi \rho \alpha ́ \tau \sigma o \\
\kappa o v \tau \alpha ́ \lambda \imath \\
\pi \alpha ́ \pi ı \alpha\end{array}$ & $\begin{array}{l}\text { 'bratso } \\
\text { ku'tali } \\
\text { 'papja }\end{array}$ & $\begin{array}{l}\pi o ́ \delta 1 \\
\pi \eta \rho o v ́ v \imath\end{array}$ & $\begin{array}{l}\text { 'poði } \\
\text { pi'runi }\end{array}$ \\
\hline 3 & $\begin{array}{l}\text { rel } \\
\text { rel } \\
\text { unrel }\end{array}$ & $\begin{array}{l}\text { sock } \\
\text { butter } \\
\text { TV }\end{array}$ & $\begin{array}{l}\text { shoe } \\
\text { bread }\end{array}$ & 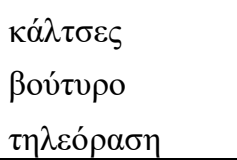 & $\begin{array}{l}\text { 'kaltses } \\
\text { 'vutiro } \\
\text { tile'orasi }\end{array}$ & $\begin{array}{l}\pi \alpha \pi \circ v^{\prime} \sigma \mathrm{l} \alpha \\
\psi \omega \mu \mathrm{i}\end{array}$ & $\begin{array}{l}\text { pa'putsja } \\
\text { pso'mi }\end{array}$ \\
\hline 4 & $\begin{array}{l}\text { rel } \\
\text { rel } \\
\text { unrel }\end{array}$ & $\begin{array}{l}\text { toes } \\
\text { moon } \\
\text { house } \\
\end{array}$ & $\begin{array}{l}\text { foot } \\
\text { sun }\end{array}$ & 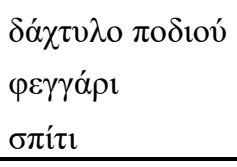 & $\begin{array}{l}\text { 'ðaxtilopo'dju } \\
\text { fe'gari } \\
\text { 'spiti }\end{array}$ & $\begin{array}{l}\pi \text { ó } \delta 1 \\
\eta ́ \lambda 10 \varsigma\end{array}$ & $\begin{array}{l}\text { 'poði } \\
\text { 'iКos }\end{array}$ \\
\hline 5 & $\begin{array}{l}\text { rel } \\
\text { rel } \\
\text { unrel }\end{array}$ & $\begin{array}{l}\text { tongue } \\
\text { egg } \\
\text { doll }\end{array}$ & $\begin{array}{l}\text { mouth } \\
\text { chicken }\end{array}$ & $\begin{array}{l}\gamma \lambda \omega ́ \sigma \sigma \alpha \\
\alpha v \gamma \delta ́ \\
\kappa о \cup ́ \kappa \lambda \alpha\end{array}$ & $\begin{array}{l}\text { 'ylosa } \\
\text { av'yo } \\
\text { 'kukla }\end{array}$ & $\begin{array}{l}\sigma \tau o ́ \mu \alpha \\
\kappa о \tau о \pi о \nu \lambda \alpha ́ \kappa 1\end{array}$ & $\begin{array}{l}\text { 'stoma } \\
\text { kotopu'laki }\end{array}$ \\
\hline 6 & $\begin{array}{l}\text { rel } \\
\text { rel } \\
\text { unrel }\end{array}$ & $\begin{array}{l}\text { hand } \\
\text { tiger } \\
\text { stairs }\end{array}$ & $\begin{array}{l}\text { finger } \\
\text { lion }\end{array}$ & $\begin{array}{l}\chi \varepsilon ́ \rho 1 \\
\tau i ́ \gamma \rho \eta \\
\sigma \kappa \alpha ́ \lambda \varepsilon \varsigma\end{array}$ & $\begin{array}{l}\text { 'çeri } \\
\text { 'tiyri } \\
\text { 'skales }\end{array}$ & 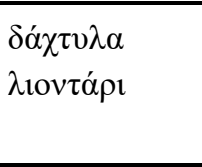 & $\begin{array}{l}\text { 'oaxtila } \\
\text { Ko'dari }\end{array}$ \\
\hline 7 & $\begin{array}{l}\text { rel } \\
\text { rel } \\
\text { unrel }\end{array}$ & $\begin{array}{l}\text { glasses } \\
\text { bus } \\
\text { monkey }\end{array}$ & $\begin{array}{l}\text { eyes } \\
\text { car }\end{array}$ & $\begin{array}{l}\gamma v \alpha \lambda i \alpha ́ \\
\lambda \varepsilon \omega \varphi \circ \rho \varepsilon i ́ o \\
\mu \alpha \ddot{\mu} \mu v^{\prime}\end{array}$ & $\begin{array}{l}\text { ja'Ka } \\
\text { leofo'rio } \\
\text { mai'mu }\end{array}$ & 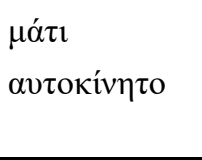 & $\begin{array}{l}\text { 'mati } \\
\text { afto'kinito }\end{array}$ \\
\hline 8 & $\begin{array}{l}\text { rel } \\
\text { rel } \\
\text { unrel }\end{array}$ & $\begin{array}{l}\text { coat } \\
\text { elephant } \\
\text { bike } \\
\end{array}$ & $\begin{array}{l}\text { hat } \\
\text { mouse }\end{array}$ & $\begin{array}{l}\pi \alpha \lambda \tau{ }^{\prime} \\
\varepsilon \lambda \varepsilon ́ \varphi \alpha \nu \tau \alpha \varsigma \\
\pi \circ \delta \eta ́ \lambda \alpha \tau o\end{array}$ & $\begin{array}{l}\text { pal'to } \\
\text { e'lefandas } \\
\text { po'ðilato }\end{array}$ & 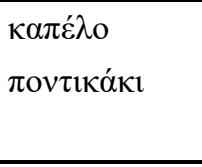 & $\begin{array}{l}\text { ka'pelo } \\
\text { pondi'kaki }\end{array}$ \\
\hline 9 & $\begin{array}{l}\text { rel } \\
\text { rel }\end{array}$ & $\begin{array}{l}\text { ear } \\
\text { window }\end{array}$ & $\begin{array}{l}\text { nose } \\
\text { door }\end{array}$ & $\begin{array}{l}\alpha v \tau i ́ \\
\pi \alpha \rho \alpha ́ \theta v \rho o\end{array}$ & $\begin{array}{l}\text { af'ti } \\
\text { pa'ra } \theta \text { iro }\end{array}$ & $\begin{array}{l}\mu v^{\prime} \tau \eta \\
\pi \delta ́ \rho \tau \alpha\end{array}$ & $\begin{array}{l}\text { 'miti } \\
\text { 'porta }\end{array}$ \\
\hline
\end{tabular}




\begin{tabular}{|c|c|c|c|c|c|c|c|}
\hline & unrel & boat & & $\pi \lambda$ oío & 'plio & & \\
\hline 10 & $\begin{array}{l}\text { rel } \\
\text { rel } \\
\text { unrel }\end{array}$ & $\begin{array}{l}\text { park } \\
\text { balloon } \\
\text { scissors }\end{array}$ & $\begin{array}{l}\text { tree } \\
\text { ball }\end{array}$ & $\begin{array}{l}\pi \alpha \dot{\alpha} \kappa о \\
\mu \pi \alpha \lambda o ́ v 1 \\
\psi \alpha \lambda i ́ \delta 1\end{array}$ & $\begin{array}{l}\text { 'parko } \\
\text { ba'loni } \\
\text { psa'liði }\end{array}$ & 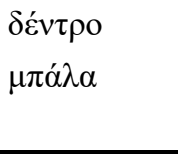 & $\begin{array}{l}\text { 'ðendro } \\
\text { 'bala }\end{array}$ \\
\hline 11 & $\begin{array}{l}\text { rel } \\
\text { rel } \\
\text { unrel }\end{array}$ & $\begin{array}{l}\text { swing } \\
\text { cereal } \\
\text { penguin }\end{array}$ & $\begin{array}{l}\text { slide } \\
\text { bowl }\end{array}$ & 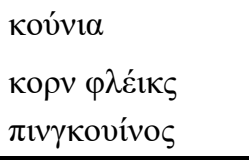 & $\begin{array}{l}\text { 'kuna } \\
\text { korn'fleiks } \\
\text { pingu'inos }\end{array}$ & $\begin{array}{l}\tau \sigma o v \lambda \eta \dot{\theta} \theta \rho \alpha \\
\mu \pi \mathrm{o} \lambda\end{array}$ & 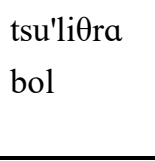 \\
\hline 12 & $\begin{array}{l}\text { rel } \\
\text { rel } \\
\text { unrel }\end{array}$ & $\begin{array}{l}\text { apple } \\
\text { fish } \\
\text { potty }\end{array}$ & $\begin{array}{l}\text { banana } \\
\text { frog }\end{array}$ & 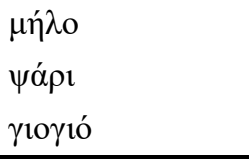 & $\begin{array}{l}\text { 'milo } \\
\text { 'psari } \\
\text { jo'jo }\end{array}$ & $\begin{array}{l}\mu \pi \alpha v \alpha ́ v \alpha \\
\beta \alpha ́ \tau \rho \alpha \chi 0 \varsigma\end{array}$ & $\begin{array}{l}\text { ba'nana } \\
\text { 'vatraxos }\end{array}$ \\
\hline 13 & $\begin{array}{l}\text { rel } \\
\text { rel } \\
\text { unrel }\end{array}$ & $\begin{array}{l}\text { cake } \\
\text { sky } \\
\text { pillow }\end{array}$ & $\begin{array}{l}\text { biscuit } \\
\text { bird }\end{array}$ & 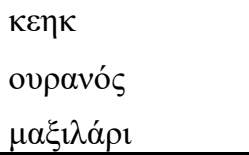 & $\begin{array}{l}\text { 'keik } \\
\text { ura'nos } \\
\text { maksi'lari }\end{array}$ & $\begin{array}{l}\mu \pi \imath \sigma \kappa o ́ \tau o \\
\pi 0 v \lambda i ́\end{array}$ & $\begin{array}{l}\text { bi'skoto } \\
\text { pu'li }\end{array}$ \\
\hline 14 & $\begin{array}{l}\text { rel } \\
\text { rel } \\
\text { unrel }\end{array}$ & $\begin{array}{l}\text { carrot } \\
\text { button } \\
\text { soap } \\
\end{array}$ & $\begin{array}{l}\text { peas } \\
\text { trousers }\end{array}$ & 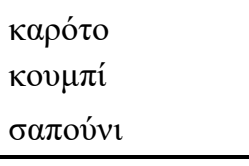 & $\begin{array}{l}\text { ka'roto } \\
\text { kum'bi } \\
\text { sa'puni } \\
\end{array}$ & $\begin{array}{l}\alpha \rho \alpha \kappa \alpha ́ \varsigma \\
\pi \alpha \nu \tau \varepsilon \lambda o ́ v i \alpha\end{array}$ & $\begin{array}{l}\text { ara'kas } \\
\text { pande'loni }\end{array}$ \\
\hline 15 & $\begin{array}{l}\text { rel } \\
\text { rel } \\
\text { unrel }\end{array}$ & $\begin{array}{l}\text { sheep } \\
\text { lorry } \\
\text { money }\end{array}$ & $\begin{array}{l}\text { cow } \\
\text { train }\end{array}$ & 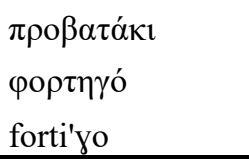 & $\begin{array}{l}\text { prova'taki } \\
\text { forti'yo } \\
\text { le'fta }\end{array}$ & 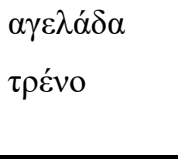 & $\begin{array}{l}\text { aje'laða } \\
\text { 'treno }\end{array}$ \\
\hline 16 & $\begin{array}{l}\text { rel } \\
\text { rel } \\
\text { unrel }\end{array}$ & $\begin{array}{l}\text { bee } \\
\text { cup } \\
\text { bubble }\end{array}$ & $\begin{array}{l}\text { flower } \\
\text { milk }\end{array}$ & 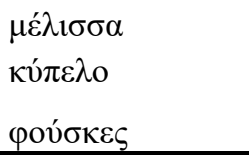 & $\begin{array}{l}\text { 'melisa } \\
\text { 'kipelo } \\
\text { 'fuskes }\end{array}$ & 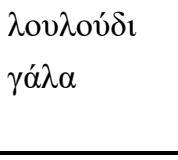 & $\begin{array}{l}\text { lu'luði } \\
\text { 'yala }\end{array}$ \\
\hline 17 & $\begin{array}{l}\text { rel } \\
\text { rel } \\
\text { unrel }\end{array}$ & $\begin{array}{l}\text { nappy } \\
\text { picture } \\
\text { giraffe } \\
\end{array}$ & $\begin{array}{l}\text { bib } \\
\text { book }\end{array}$ & $\begin{array}{l}\pi \alpha ́ v \alpha \\
\varphi \omega \tau о \gamma \rho \alpha \varphi \dot{\alpha} \alpha \\
\kappa \alpha \mu \eta \lambda о \pi \alpha ́ \rho \delta \alpha \lambda \eta\end{array}$ & $\begin{array}{l}\text { 'pana } \\
\text { fotoyra'fia } \\
\text { kamilo'parðali }\end{array}$ & $\begin{array}{l}\sigma \alpha \lambda ı \alpha ́ \rho \alpha \\
\beta ı \beta \lambda i ́ o\end{array}$ & $\begin{array}{l}\text { sa'Kara } \\
\text { vi'vlio }\end{array}$ \\
\hline 18 & $\begin{array}{l}\text { rel } \\
\text { rel } \\
\text { unrel }\end{array}$ & $\begin{array}{l}\text { orange } \\
\text { pyjamas } \\
\text { towel }\end{array}$ & $\begin{array}{l}\text { cheese } \\
\text { bed }\end{array}$ & $\begin{array}{l}\pi о \rho \tau о \kappa \alpha ́ \lambda t \\
\pi \nu \tau \zeta \alpha ́ \mu \varepsilon \varsigma \\
\pi \varepsilon \tau \sigma \varepsilon ́ \tau \alpha\end{array}$ & $\begin{array}{l}\text { porto'kali } \\
\text { pi'dzames } \\
\text { pe'tseta }\end{array}$ & $\begin{array}{l}\tau v \rho i ́ \\
\kappa \rho \varepsilon \beta \alpha ́ \tau \imath\end{array}$ & $\begin{array}{l}\text { ti'ri } \\
\text { kre'vati }\end{array}$ \\
\hline 19 & $\begin{array}{l}\text { rel } \\
\text { rel } \\
\text { unrel }\end{array}$ & $\begin{array}{l}\text { plate } \\
\text { toothbrush } \\
\text { horse }\end{array}$ & $\begin{array}{l}\text { bottle } \\
\text { bath }\end{array}$ & 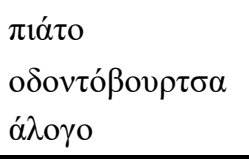 & $\begin{array}{l}\text { 'pjato } \\
\text { oðon'dovurtsa } \\
\text { 'aloyo }\end{array}$ & 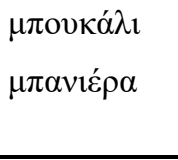 & $\begin{array}{l}\text { bu'kali } \\
\text { ba'nera }\end{array}$ \\
\hline 20 & $\begin{array}{l}\text { rel } \\
\text { rel } \\
\text { unrel }\end{array}$ & $\begin{array}{l}\text { toys } \\
\text { water } \\
\text { key }\end{array}$ & $\begin{array}{l}\text { blocks } \\
\text { juice }\end{array}$ & $\begin{array}{l}\pi \alpha \imath \chi v i ́ \delta ı \\
\nu \varepsilon \rho o ́ \\
\kappa \lambda \varepsilon ı 1 \delta i ́\end{array}$ & $\begin{array}{l}\text { pex'niði } \\
\text { ne'ro } \\
\text { kli'ði }\end{array}$ & 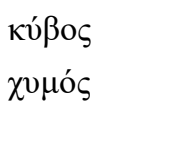 & $\begin{array}{l}\text { 'kivos } \\
\text { çi'mos }\end{array}$ \\
\hline
\end{tabular}

\begin{tabular}{|ll|ll|llll|}
\hline & & English & & Mandarin & & \\
& & primes & targets & primes & targets \\
\hline 1 & rel & table & chair & 飯桌 & fàn zhuō & 椅子 & y̌̃ zi \\
& rel & dog & cat & 狗 & gǒu & māo & \\
& unrel & aeroplane & & 飛機 & fēi jī & & \\
\hline
\end{tabular}




\begin{tabular}{|c|c|c|c|c|c|c|c|}
\hline 2 & $\begin{array}{l}\text { rel } \\
\text { rel } \\
\text { unrel } \\
\end{array}$ & $\begin{array}{l}\text { arm } \\
\text { spoon } \\
\text { duck } \\
\end{array}$ & $\begin{array}{l}\text { leg } \\
\text { fork }\end{array}$ & $\begin{array}{l}\text { 手臂 } \\
\text { 湯匙 } \\
\text { 鸭子 } \\
\end{array}$ & $\begin{array}{l}\text { shǒu bì } \\
\text { tāng chi } \\
\text { yā zi }\end{array}$ & $\begin{array}{l}\text { 腿 } \\
\text { 叉子 }\end{array}$ & $\begin{array}{l}\text { tuǐ } \\
\text { chā zi }\end{array}$ \\
\hline 3 & $\begin{array}{l}\text { rel } \\
\text { rel } \\
\text { unrel } \\
\end{array}$ & $\begin{array}{l}\text { sock } \\
\text { butter } \\
\text { TV } \\
\end{array}$ & $\begin{array}{l}\text { shoe } \\
\text { bread }\end{array}$ & $\begin{array}{l}\text { 襪子 } \\
\text { 黄油 } \\
\text { 电视 }\end{array}$ & $\begin{array}{l}\text { wàzi } \\
\text { huáng yóu } \\
\text { diàn shì }\end{array}$ & $\begin{array}{l}\text { 鞋 } \\
\text { 面包 }\end{array}$ & $\begin{array}{l}\text { xié } \\
\text { miàn bāo }\end{array}$ \\
\hline 4 & $\begin{array}{l}\text { rel } \\
\text { rel } \\
\text { unrel } \\
\end{array}$ & $\begin{array}{l}\text { toes } \\
\text { moon } \\
\text { house }\end{array}$ & $\begin{array}{l}\text { foot } \\
\text { sun }\end{array}$ & $\begin{array}{l}\text { 脚趾 } \\
\text { 月亮 } \\
\text { 房子 } \\
\end{array}$ & $\begin{array}{l}\text { jiăo zhǐ } \\
\text { yuè liàng } \\
\text { fáng zi }\end{array}$ & $\begin{array}{l}\text { 脚 } \\
\text { 太陽 }\end{array}$ & $\begin{array}{l}\text { jiăo } \\
\text { tài yáng }\end{array}$ \\
\hline 5 & $\begin{array}{l}\text { rel } \\
\text { rel } \\
\text { unrel } \\
\end{array}$ & $\begin{array}{l}\text { tongue } \\
\text { egg } \\
\text { doll } \\
\end{array}$ & $\begin{array}{l}\text { mouth } \\
\text { chicken }\end{array}$ & $\begin{array}{l}\text { 舌头 } \\
\text { 蛋 } \\
\text { 洋娃娃 } \\
\end{array}$ & $\begin{array}{l}\text { shé tou } \\
\text { dàn } \\
\text { yáng wá wá }\end{array}$ & $\begin{array}{l}\text { 嘴 } \\
\text { 䌖 }\end{array}$ & $\begin{array}{l}\text { zuĭ } \\
\text { jī }\end{array}$ \\
\hline 6 & $\begin{array}{l}\text { rel } \\
\text { rel } \\
\text { unrel } \\
\end{array}$ & $\begin{array}{l}\text { hand } \\
\text { tiger } \\
\text { stairs }\end{array}$ & $\begin{array}{l}\text { finger } \\
\text { lion }\end{array}$ & $\begin{array}{l}\text { 手 } \\
\text { 老虎 } \\
\text { 楼梯 }\end{array}$ & $\begin{array}{l}\text { shǒu } \\
\text { lǎo hǔ } \\
\text { lóu tī }\end{array}$ & $\begin{array}{l}\text { 手指頭 } \\
\text { 狮子 }\end{array}$ & $\begin{array}{l}\text { shǒu zhǐ tou } \\
\text { shī zi }\end{array}$ \\
\hline 7 & $\begin{array}{l}\text { rel } \\
\text { rel } \\
\text { unrel } \\
\end{array}$ & $\begin{array}{l}\text { glasses } \\
\text { bus } \\
\text { monkey }\end{array}$ & $\begin{array}{l}\text { eyes } \\
\text { car }\end{array}$ & $\begin{array}{l}\text { 眼镜 } \\
\text { 公車 } \\
\text { 猴子 } \\
\end{array}$ & $\begin{array}{l}\text { yăn jìng } \\
\text { gōng chē } \\
\text { hóu zi }\end{array}$ & $\begin{array}{l}\text { 眼睛 } \\
\text { 車子 }\end{array}$ & $\begin{array}{l}\text { yăn jīng } \\
\text { chē zi }\end{array}$ \\
\hline 8 & $\begin{array}{l}\text { rel } \\
\text { rel } \\
\text { unrel } \\
\end{array}$ & $\begin{array}{l}\text { coat } \\
\text { elephant } \\
\text { bike } \\
\end{array}$ & $\begin{array}{l}\text { hat } \\
\text { mouse }\end{array}$ & $\begin{array}{l}\text { 外套 } \\
\text { 大象 } \\
\text { 腳踏車 } \\
\end{array}$ & $\begin{array}{l}\text { wài tào } \\
\text { dà xiàng } \\
\text { jiăo tà chē }\end{array}$ & $\begin{array}{l}\text { 帽子 } \\
\text { 老鼠 }\end{array}$ & $\begin{array}{l}\text { mào zi } \\
\text { lăo shǔ }\end{array}$ \\
\hline 9 & $\begin{array}{l}\text { rel } \\
\text { rel } \\
\text { unrel } \\
\end{array}$ & $\begin{array}{l}\text { ear } \\
\text { window } \\
\text { boat } \\
\end{array}$ & $\begin{array}{l}\text { nose } \\
\text { door }\end{array}$ & $\begin{array}{l}\text { 耳朵 } \\
\text { 窗户 } \\
\text { 船 } \\
\end{array}$ & $\begin{array}{l}\text { Ěrduǒ } \\
\text { chuān ghù } \\
\text { chuán }\end{array}$ & $\begin{array}{l}\text { 鼻子 } \\
\text { 門 }\end{array}$ & $\begin{array}{l}\text { bí zi } \\
\text { mén }\end{array}$ \\
\hline 10 & $\begin{array}{l}\text { rel } \\
\text { rel } \\
\text { unrel } \\
\end{array}$ & $\begin{array}{l}\text { park } \\
\text { balloon } \\
\text { scissors } \\
\end{array}$ & $\begin{array}{l}\text { tree } \\
\text { ball }\end{array}$ & $\begin{array}{l}\text { 公园 } \\
\text { 氣球 } \\
\text { 剪刀 }\end{array}$ & $\begin{array}{l}\text { gōn gyuán } \\
\text { qì qiú } \\
\text { jiăn dāo }\end{array}$ & $\begin{array}{l}\text { 樹 } \\
\text { 球 }\end{array}$ & $\begin{array}{l}\text { shù } \\
\text { qiú }\end{array}$ \\
\hline 11 & $\begin{array}{l}\text { rel } \\
\text { rel } \\
\text { unrel }\end{array}$ & $\begin{array}{l}\text { swing } \\
\text { cereal } \\
\text { penguin }\end{array}$ & $\begin{array}{l}\text { slide } \\
\text { bowl }\end{array}$ & $\begin{array}{l}\text { 秋千 } \\
\text { 麥片 } \\
\text { 企鹅 }\end{array}$ & $\begin{array}{l}\text { qiū qiān } \\
\text { mài piàn } \\
\text { qî é }\end{array}$ & $\begin{array}{l}\text { 滑梯 } \\
\text { 碗 }\end{array}$ & $\begin{array}{l}\text { huá tī } \\
\text { wăn }\end{array}$ \\
\hline 12 & $\begin{array}{l}\text { rel } \\
\text { rel } \\
\text { unrel } \\
\end{array}$ & $\begin{array}{l}\text { apple } \\
\text { fish } \\
\text { potty }\end{array}$ & $\begin{array}{l}\text { banana } \\
\text { frog }\end{array}$ & $\begin{array}{l}\text { 蘋果 } \\
\text { 鱼 } \\
\text { 便盆 } \\
\end{array}$ & $\begin{array}{l}\text { píng guǒ } \\
\text { yú } \\
\text { biàn pén }\end{array}$ & $\begin{array}{l}\text { 香蕉 } \\
\text { 青蛙 }\end{array}$ & $\begin{array}{l}\text { xiāng jiāo } \\
\text { qīng wā }\end{array}$ \\
\hline 13 & $\begin{array}{l}\text { rel } \\
\text { rel } \\
\text { unrel } \\
\end{array}$ & $\begin{array}{l}\text { cake } \\
\text { sky } \\
\text { pillow }\end{array}$ & $\begin{array}{l}\text { biscuit } \\
\text { bird }\end{array}$ & $\begin{array}{l}\text { 蛋糕 } \\
\text { 天（空） } \\
\text { 枕頭 }\end{array}$ & $\begin{array}{l}\text { dàn gāo } \\
\text { tiān kōng } \\
\text { zhěn tou }\end{array}$ & $\begin{array}{l}\text { 餅乾 } \\
\text { 鸟 }\end{array}$ & $\begin{array}{l}\text { bǐng gān } \\
\text { niăo }\end{array}$ \\
\hline 14 & $\begin{array}{l}\text { rel } \\
\text { rel } \\
\text { unrel } \\
\end{array}$ & $\begin{array}{l}\text { carrot } \\
\text { button } \\
\text { soap }\end{array}$ & $\begin{array}{l}\text { peas } \\
\text { trousers }\end{array}$ & $\begin{array}{l}\text { 胡萝卜 } \\
\text { 扣子 } \\
\text { 肥皇 }\end{array}$ & $\begin{array}{l}\text { hú luó bo } \\
\text { kòu zi } \\
\text { féi zào }\end{array}$ & $\begin{array}{l}\text { 豌豆 } \\
\text { 裤子 }\end{array}$ & $\begin{array}{l}\text { wān dòu } \\
\text { kù zi }\end{array}$ \\
\hline 15 & $\begin{array}{l}\text { rel } \\
\text { rel } \\
\text { unrel } \\
\end{array}$ & $\begin{array}{l}\text { sheep } \\
\text { lorry } \\
\text { money } \\
\end{array}$ & $\begin{array}{l}\text { cow } \\
\text { train }\end{array}$ & $\begin{array}{l}\text { 羊 } \\
\text { 卡车 } \\
\text { 錢 } \\
\end{array}$ & $\begin{array}{l}\text { yáng } \\
\text { kă chē } \\
\text { qián }\end{array}$ & $\begin{array}{l}\text { 牛 } \\
\text { 火車 }\end{array}$ & $\begin{array}{l}\text { niú } \\
\text { huǒ chē }\end{array}$ \\
\hline 16 & & $\begin{array}{l}\text { bee } \\
\text { cup }\end{array}$ & $\begin{array}{l}\text { flower } \\
\text { milk }\end{array}$ & $\begin{array}{l}\text { 蜜蜂 } \\
\text { 杯子 }\end{array}$ & $\begin{array}{l}\text { mì fēng } \\
\text { bēi zi }\end{array}$ & $\begin{array}{l}\text { 花 } \\
\text { 牛奶 }\end{array}$ & $\begin{array}{l}\text { huā } \\
\text { niú năi }\end{array}$ \\
\hline
\end{tabular}




\begin{tabular}{|c|c|c|c|c|c|c|c|}
\hline & unrel & bubble & & 泡泡 & pào pào & & \\
\hline 17 & $\begin{array}{l}\text { rel } \\
\text { rel } \\
\text { unrel } \\
\end{array}$ & $\begin{array}{l}\text { nappy } \\
\text { picture } \\
\text { giraffe } \\
\end{array}$ & $\begin{array}{l}\text { bib } \\
\text { book }\end{array}$ & $\begin{array}{l}\text { 尿布 } \\
\text { 圖片 } \\
\text { 長頸鹿 } \\
\end{array}$ & $\begin{array}{l}\text { niào bù } \\
\text { tú piàn } \\
\text { cháng jǐng lù }\end{array}$ & $\begin{array}{l}\text { 围㝸 } \\
\text { 書 }\end{array}$ & $\begin{array}{l}\text { wéi dōu } \\
\text { shū }\end{array}$ \\
\hline 18 & $\begin{array}{l}\text { rel } \\
\text { rel } \\
\text { unrel } \\
\end{array}$ & $\begin{array}{l}\text { orange } \\
\text { pyjamas } \\
\text { towel }\end{array}$ & $\begin{array}{l}\text { cheese } \\
\text { bed }\end{array}$ & $\begin{array}{l}\text { 桔子 } \\
\text { 睡衣 } \\
\text { 毛巾 } \\
\end{array}$ & $\begin{array}{l}\text { jú zi } \\
\text { shuì yī } \\
\text { máo jīn } \\
\end{array}$ & $\begin{array}{l}\text { 奶酪 } \\
\text { 床 }\end{array}$ & $\begin{array}{l}\text { năi lào } \\
\text { chuáng }\end{array}$ \\
\hline 19 & $\begin{array}{l}\text { rel } \\
\text { rel } \\
\text { unrel } \\
\end{array}$ & $\begin{array}{l}\text { plate } \\
\text { toothbrush } \\
\text { horse } \\
\end{array}$ & $\begin{array}{l}\text { bottle } \\
\text { bath }\end{array}$ & $\begin{array}{l}\text { 盘子 } \\
\text { 牙刷 } \\
\text { 馬 } \\
\end{array}$ & $\begin{array}{l}\text { pán zi } \\
\text { yá shuā } \\
\text { mă }\end{array}$ & $\begin{array}{l}\text { 奶瓶 } \\
\text { 澡盆 }\end{array}$ & $\begin{array}{l}\text { năi píng } \\
\text { zăo pén }\end{array}$ \\
\hline 20 & $\begin{array}{l}\text { rel } \\
\text { rel } \\
\text { unrel } \\
\end{array}$ & $\begin{array}{l}\text { toys } \\
\text { water } \\
\text { key }\end{array}$ & $\begin{array}{l}\text { blocks } \\
\text { juice }\end{array}$ & $\begin{array}{l}\text { 玩具 } \\
\text { 水 } \\
\text { 錀题 }\end{array}$ & $\begin{array}{l}\text { wán jù } \\
\text { shuî } \\
\text { yào shi }\end{array}$ & $\begin{array}{l}\text { 積木 } \\
\text { 果汁 }\end{array}$ & $\begin{array}{l}\text { jī mù } \\
\text { guǒ zhī }\end{array}$ \\
\hline
\end{tabular}


Appendix C

Initial run of Experiment 1 with an SOA at $0 \mathrm{~ms}$

This initial first experiment tested priming between translation equivalents, e.g. dog - chien (French translation of dog) in 27-month-old bilingual toddlers. All details are similar to Experiment 1, apart from an SOA at $0 \mathrm{~ms}$ between the onset of the target word and the presentation of the two pictures, against a 200 ms SOA in Experiment 1.

\section{Method}

\section{Participants}

A total of 28 children were successfully tested, aged 27;16 (from 25;12 to 30;6; 10 girls and 18 boys). Their home language was Dutch $(N=2)$, French $(N=5)$, German $(N=6)$, Italian ( $\mathrm{N}=4)$, Mandarin $(\mathrm{N}=1)$, Polish $(\mathrm{N}=5)$, and Spanish $(\mathrm{N}=5)$. Their average exposure to English in a typical week as measured by the LEQ (Cattani et al., 2014) was $51.1 \%$ (SD = 26.1). Their average English vocabulary score in the 100-word Oxford CDI (Floccia et al., 2018) was 79.9 words in comprehension $(S D=20.1)$ and 57.3 in production (SD $=26.2)$. Their vocabulary scores in their home language were obtained through the appropriate CDIs (missing data for 4 children). The resulting average vocabulary score in the home language was $75.5 \%$ in comprehension ( $S D=21.8$ ) and $38.9 \%$ in production (SD $=25.9)$.

The data of an additional group of 16 toddlers were discarded because of incomplete key data set (missing English vocabulary data: $N=2)$, technical problems $(\mathrm{N}=3)$, trilingualism ( $N=4)$, and insufficient vocabulary knowledge ( $N=7$; see result section). All children came from comparable middle-to-higher-class families.

Stimuli and procedure 
Identical to those used in Experiment 1, apart from SOA. The duration of the pre-trial period was 3200 ms for the French, Polish, Spanish, German and Dutch conditions, and 4200 ms for Italian and Mandarin, as sentences were on average longer in those languages. Two hundred ms after the offset of the prime, the target word began, together with the presentation of the two images, which remained on screen for 2500 ms.

\section{$\underline{\text { Results }}$}

Trials in which the child did not know the prime and the target in the language of presentation as reported on the word checklist on the day of testing were excluded from the analyses; in addition, a trial was deemed valid if the child fixated at least one picture at some point. Children were excluded if, as a result, they had less than 16 valid trials out of 40 (see participant section; these children are referred to as having too small a vocabulary). In the final dataset of 28 children, there were an average of 27.75 valid trials per child out of $40(S D=7.3)$.

The dependent variable was the proportion of looking time towards the target (PLT), calculated as the amount of looking time towards the target divided by the total looking time towards target and distracter, in each trial. The window of analysis was 0-2000 ms from the onset of the target word. Inspection of the PLT time course showed that any differences between conditions are located within the first $1400 \mathrm{~ms}$ of test trials. Analyses of looking times, therefore, focus on this time 0-2000 ms window (Mirman, 2016).

\section{Evaluating dominance}

To analyse priming data as a function of language dominance, we classified children as English or Home Language $(\mathrm{HL})$ dominant using two different estimates: either their relative amount of exposure to English versus the $\mathrm{HL}$, or their level of vocabulary knowledge in English. Note that the amount of exposure significantly predicted the English 
CDI comprehension scores $(r=0.31, p=.05$, one-tailed), but less so English production $(r=$ $0.25, p=.10$, one-tailed). Note also that, not unexpectedly given the variation in the Home Language CDIs, the amount of exposure to English did not predict (negatively) the HL comprehension scores $(r=-.01)$ nor the production scores $(r=.04)$.

Using the amount of exposure to English, children were grouped as English dominant $(\mathrm{N}=14)$ if they had $50 \%$ or more exposure to English, and as HL dominant otherwise $(\mathrm{N}=14)$. As expected, the English dominant children had higher vocabulary in English than the $\mathrm{HL}$ dominant children in comprehension (respectively $\mathrm{M}=84.4$ versus 75.4 ) and production (respectively $M=62.7$ versus 51.9 ) but not significantly (comprehension: $\mathrm{t}(26)=1.20$; production: $\mathrm{t}(26)=1.10)$. For $\mathrm{HL}$ vocabulary scores, $\mathrm{HL}$ dominant children understood and produced about the same number of words $(M=72.3 \%$ and $M=36.5 \%)$ as English dominant children ( $M=77.8 \% ; M=40.6 \%$; all $\mathrm{t}(22)<1)$.

Using the vocabulary scores, we grouped children in the English dominant group $(\mathrm{N}=14)$ if they scored above the group median in English in comprehension and production and in the $\mathrm{HL}$ group otherwise $(\mathrm{N}=14)$. For the majority of children $(2)$, the two scores comprehension and production - converged to predict the dominance group; for the remaining 6 children, we used comprehension scores to assign them to a dominance group. The two indexes of dominance (amount of exposure and vocabulary scores) did not match (similarity matching coefficient: 0.50 ).

\section{Evaluating language distance}

Pairs of languages (English / Home Language) were classified as close or distant using the metric of phonological overlap of translation equivalents (Floccia et al., 2018). We considered children as belonging to the close language group if they learned Dutch, 
German, Italian or French ( $\mathrm{N}=17)$ and distant languages if they learned Spanish, Polish and Mandarin ( $\mathrm{N}=11)$.

Preliminary analyses

An initial ANOVA on PLT with language of the prime (English vs. Home Language) and priming (related vs. unrelated prime-target) as repeated measures, and order of block presentation and age (covariate) as between-participant factors, did not reveal any main effect of age $(F(1,25)<1)$ or order $(F(1,25)<1)$. An interaction between order and language of the prime was found $(F(1,25)=9.11, p=.006$, eta $=.27)$, due to the fact that children generally looked longer at the target in the second block of stimuli $(60.4 \%)$ than in the first one (53.4\%), probably due to a familiarisation effect. Because no other interaction was significant, in particular none involving priming, age and order were discarded from further analyses.

Effect of priming and language of the prime

An ANOVA with language of the prime (English vs. Home Language) and priming (related vs. unrelated prime-target) as repeated measures was run on the proportion of looking times (PLT) towards the target. A main effect of priming was found $(F(1,27)=6.56$, $p=.016$, eta $=.20)$, due to longer looking times to the target in the related condition $(59.94 \%, S D=7.54 \%)$ than in the unrelated condition $(53.96 \%, S D=9.34 \%)$. No effect of the language of prime was found $(F(1,27)=2.55, p=.12)$, as looking times to the target were comparable for a prime in English $(55.09 \%, \mathrm{SD}=8.46 \%)$ or in the Home Language $(58.76 \%$, $S D=7.70 \%)$. There was no interaction between priming and language of the prime $(F(1,27)$ $<1)$.

In summary, a strong effect of priming was found overall, independent of age or order of block presentation, and irrespective of the language of the prime (or the language 
of the target), similar to what was reported in Experiments 1 and 2. In addition, and as found in Experiments 1 and 2, target recognition appears to be blocked in the unrelated condition, as bilingual children recognised the target in the unrelated condition $(53.96 \%$, SD $=9.34 \%$, t-test against chance at $50 \%: \mathrm{t}(27)=2.24, \mathrm{p}=.033)$, as well as, or course, in the related condition $(59.94 \%, \mathrm{SD}=7.54 \% ; \mathrm{t}(27)=6.98, \mathrm{p}<.0001)$.

Effect of language distance and dominance defined through exposure

An ANOVA was run on priming scores with language of the prime (English vs. Home Language) as a repeated measure, and language distance (close vs. distant) and language dominance as defined through exposure (English dominant or Home Language dominant) as between-participant factors. No main effect was found: the priming effect was similar for English primes $(5.70 \%, S D=16.62)$ and Home Language primes $(6.34 \%, S D=15.60 ; F(1,24)<$ 1), for close language learners $(5.02 \%, S D=12.84)$ and distant language learners $(7.47 \%, S D$ $=13.03 ; F(1,24)<1)$, as well as for English dominant children $(4.11 \%, S D=12.27)$ and Home Language dominant children $(7.85 \%, S D=13.26 ; F(1,24)<1)$. No interaction was significant. Effect of language distance and dominance defined through vocabulary scores

The same analysis as above was conducted, replacing language dominance as defined through exposure with language dominance as defined through vocabulary scores. As above, no main effects or interactions were found, with the priming effect similar for English dominant children $(5.27 \%, \mathrm{SD}=13.99)$ and Home Language dominant children (6.70\%, SD = 11.82; $F(1,24)<1)$.

Time-course analysis

Confirming visual inspection, it was found that the two conditions (related and unrelated) differed significantly between 616 and $1250 \mathrm{~ms}$ post target onset (cluster $t$ statistics $=250.14$, Monte Carlo $p=.0005)$. 
In summary, the results of this experiment replicate those of Experiment 1: a

priming effect for translation equivalents which is independent of dominance and language distance. 